Portland State University

PDXScholar

\title{
"A College for Women, or Something Like It": Bedford College and the Women's Higher Education Movement, 1849-1900
}

Megan Katherine Brown

Portland State University

Follow this and additional works at: https://pdxscholar.library.pdx.edu/open_access_etds Let us know how access to this document benefits you.

\section{Recommended Citation}

Brown, Megan Katherine, "'A College for Women, or Something Like It": Bedford College and the Women's Higher Education Movement, 1849-1900" (2011). Dissertations and Theses. Paper 209.

https://doi.org/10.15760/etd.209

This Thesis is brought to you for free and open access. It has been accepted for inclusion in Dissertations and Theses by an authorized administrator of PDXScholar. Please contact us if we can make this document more accessible: pdxscholar@pdx.edu. 
"A College for Women, or Something Like It":

Bedford College and the Women's Higher Education Movement, 1849-1900

by

Megan Katherine Brown

A thesis submitted in partial fulfillment of the

requirements for the degree of

Master of Arts

in

History

Thesis Committee:

Caroline Litzenberger, Chair

Patricia Schechter

Victoria Belco

Susan Danielson

Portland State University

(C)2011 


\begin{abstract}
Bedford College, established in 1849, was the first institute of higher education for women in England, and with it came the beginning of the women's higher education movement. While Bedford is often dismissed or ignored by modern scholars for not being equal to the women's colleges associated with Cambridge and Oxford, it was crucial in the development of these later colleges and was a bellwether of the women's higher education movement.

By examining personal letters and official college documents and carefully assessing later-written histories of Bedford and the other women's colleges, this thesis will explain why and how the College was successfully founded two decades before any other college for women in England. It will also include a thorough discussion of the events that occurred before and during Bedford's establishment, its enigmatic founder Elisabeth Jesser Reid and the role of the women's higher education movement in Bedford's development. This thesis will also show how the successful foundations of Girton and Newnham Colleges at Cambridge University and Lady Margaret Hall and Somerville College at Oxford were made possible by the monumental strides made by Bedford College's influence on the creation of the women's higher education movement.
\end{abstract}


To My Grandmothers,

Who always supported and encouraged my education, even if it meant I didn't call as often as I promised. 


\section{$\underline{\text { Acknowledgements }}$}

There are a number of people who helped and supported me while I researched and wrote this thesis. I am sure I did not thank them nearly enough throughout this process, and while I am also sure I have forgotten a few, they have my deepest thanks and gratitude nonetheless.

First, thanks to my advisor Caroline Litzenberger, who has my profound gratitude for her guidance and all of her hard work.

To my brother for his support through late night phone calls and offerings of delicious food.

Thanks to Jaime, Catherine and Emily for supplying an ear or a shoulder when needed, as well as the occasional cup of tea or glass of wine.

To all my fellow grad students who reminded me that I was not alone in this experience.

Thanks to Roberta for being my favorite history teacher of all time, and to Bruce and Lauren for giving mes a life-long love and appreciation of learning. 
Special thanks to Lorna and Vicky at the Royal Holloway New Bedford College Archives for being so helpful and for providing me with the documents necessary to complete this thesis.

And finally, I would like to thanks my parents, for their love, support, care packages and last minute readings of thesis chapters, and who never seemed to mind that I usually called to either complain about my thesis, ask for money, or both. 
$\underline{\text { Table of Contents }}$

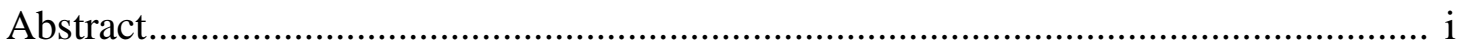

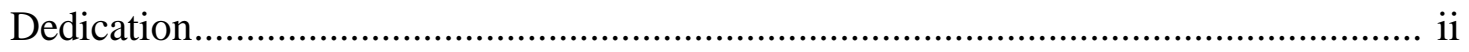

Acknowledgements .................................................................................. iii

Introduction

"Launching the Ship" ............................................................................ 1

Chapter One

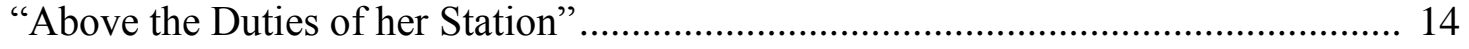

Chapter Two

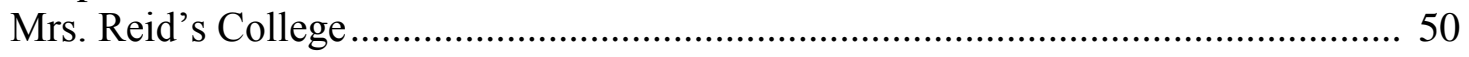

Chapter Three

"The Larger Light of Experience" .................................................................. 99

Conclusion

"Leaves of Many Shapes and Colours".

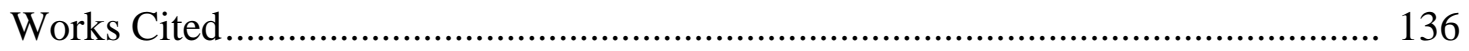


"Launching the Ship":

$\underline{\text { An Introduction }}$

They fed her theories, in and out of place

Maintaining that with equal husbandry

The women were an equal to the man.

They harp'd on this; with this our banquets rang;

Our dances broke and buzz'd in the knots of talk.

-The Princess, Act I

Founded in 1849 by wealthy widow Elisabeth Jesser Reid, Bedford College for Women was the first non-training college for women in England. It was created as a place for women to obtain an education for the purposes of bettering themselves, as opposed to training colleges, which trained men and women in specific fields.

Eighteen months earlier in 1848, Frederick D. Maurice had founded Queen's College, which was an extension of the Governesses Benevolence Institution. As a training college, Queen's was designed to prepare girls and young women of the lower and middle classes to become governesses. Meanwhile, for Reid and her followers the sole purpose of education was not to gain employment, but to become properly educated so that women might be better wives to their husband and better mothers to their children. In turn, their husbands and their children would become better educated and happier, and eventually become better citizens of the British Nation. However, the notion of granting higher education to women had been around for had been around for over a century at the time of Bedford's establishment. Bathsua Makin and Mary Astor had attempted to use the same arguments in the seventeenth century in their 
unsuccessful push for women's education. ${ }^{1}$ Thus, the question of why Reid and Bedford College were able to succeed where previous efforts had failed must be asked.

This thesis will discuss the establishment of Bedford College for Women, and the events surrounding its foundation and will attempt to discover why and how the college was able to succeed two decades before the establishment of another women's college. Though Bedford is often dismissed and overlooked by contemporaneous and modern scholars alike, Elisabeth Reid's College should be viewed as a bellwether for the women's higher education movement and simultaneously, as a substantial influence on the development of this movement. Bedford's establishment also contributed in important ways to the success of the other women's colleges established later in the century. Guided by the principles of her faith and by the social ferment created by women involved with the emerging social movement, Reid would establish Bedford as an institution where women could gain an education for the purposes of bettering themselves and their families. Early movements such as the Abolitionist movement had created a safe entryway for women into the public sphere, generating momentum that would carry through the movements that would follow, including universal enfranchisement, women's suffrage and, most important to the scope of this thesis, the women's higher education movement.

Though the College faced bankruptcy and closure several times, Bedford was able to remain open through the strong leadership, determination and the stubbornness

\footnotetext{
${ }^{1}$ Elizabeth Seymour Eschbach, The Higher Education of Women in England and America, 1865 -1920 (New York: Garland Publishing, Inc., 1993), 10.
} 
of Elisabeth Reid, and through the support of the women's higher education movement. Following Reid's death, the management of Bedford was passed on to the women of the Reid Trust, who would ultimately propel the College into a thriving success and provide a foundation for the women's colleges of Cambridge and Oxford. Much in the same way as the Abolitionist movement had created access for women into the public sphere, Bedford granted women an entryway into higher education and provided proof that education was not detrimental to the mind and psyche of women, as many feared it would be.

While the women's higher education movement was a key component to the success of Bedford, religion and social class also played a large. A wealthy uppermiddle-class widow, Reid was a member of the Unitarian church, whose beliefs carried over into the creation of her college. Women from any class were accepted into the college, based on a sliding tuition scale, and those who could not afford to pay were often granted generous scholarships from Reid herself. In addition, unlike Queen's College, which only accepted members of the Anglican faith, women from most religions including those of the Jewish faith were admitted to the College. While some of this wide acceptance can be attributed to the need for a larger student body, much of it was due to Reid's Unitarianism, which would eventually serve to hinder the College by painting it with a coat of suspicion and unorthodoxy. Yet, Bedford managed to both survive and thrive in spite of this mark against it.

Upon her death in 1866 , Reid established a sizeable trust (over $£ 10,000$ ) to support Bedford, with the condition that the Board of Trustees be run by three 
unmarried women. Furthermore, if any of these women were to become married, another unmarried woman would be required take her place. ${ }^{2}$ This structure was significantly different from Queen's College, which was founded and run by men, and different from later women's colleges, some of which were founded by women, but all of which were run by men. What effects did the minimal amount of male influence have on the emerging character of the college? It would be another twenty years before another successful women's college, Girton College at Cambridge (1869), was founded and another nine years to 1878 , before women would be allowed to sit for examinations and granted university degrees at any institution in England. Why was there such a large gap between the founding of Bedford and the founding of Girton? How much did the success of Bedford's establishment play into the eventual foundation of Girton, and the subsequent women's colleges of Newnham College (Cambridge, 1871), Lady Margaret Hall (Oxford, 1878), and Somerville College (Oxford, 1879). ${ }^{3}$ All of these questions will be explored in this thesis to some extent, but the central focus will be on the creation and the early years of Bedford College from 1849 until 1900, at which point the college became a constituent college of the University of London.

While the study of women's education and even the study of Bedford College is not an entirely new topic, there are several gaps and errors in their history that this thesis aims to fill and correct. The most salient work on the College is that of Dame

\footnotetext{
2 Tuke, 90-100.

${ }^{3}$ Carol Dyhouse, No Distinction of Sex? Women in British Universities, 1870- 1939. (London: University College London Press, 1995), 20-45.
} 
Margaret Tuke, principal of the college from 1907 to 1929. Though her work, $A$ History of Bedford College for Women, 1849-1837 written in 1939, certainly contains a rich history of the college, its founder and its students, it is more than slightly problematic for a contemporary scholar. ${ }^{4}$ It was written in the midst of World War II, when the college was facing a drop in enrollment and a lack of incoming funds. ${ }^{5}$ In an attempt to increase enrollment Tuke wrote a romanticized history of the college, which spoke of triumph in the face of adversary, overcoming naysayers, doubt and oppression and creating a college open to any and all women who wished to learn. While the book was written for an audience in need of such a story, and was well received, it glossed over parts of the college history, embellished facts and idealized the founding of the college. This point is most clearly seen in the titles of her chapters, which include such grandiose labels as "The Pioneer," "Launching of The Ship" and "The Navigators," all following a vague nautical theme. Tuke also made hasty statements concerning some famous alleged "alumni," such as George Eliot, who most likely never actually attended the College. This is not to suggest that the women of Bedford, and Reid in particular, were not remarkable or even heroic, but rather, that in idealizing the foundation of the college Tuke misses the larger historical narrative. Nowhere in her work does she mention outside forces, or hint at any reason why the college was able to succeed, beyond the resourcefulness and resilience of the founders.

\footnotetext{
${ }^{4}$ See Tuke.

${ }^{5}$ Indeed the College had lost over 200 students in the three years before the publication of Tuke's work, and had suffered a £5,000 loss in income. Tuke, Chart II, n.p.; Chart V, n.p.
} 
The loss of a substantial proportion of the primary sources referred to by Tuke presents yet another related challenge to the modern historian.

Tuke's romanticizing was a distinct trend among the writers of the histories of the women's college. All of the colleges mentioned above have a major published history, all written by women who had personal ties to their subjects and who idealized their histories and all of whom minimize the impact of outside influences. In fact, almost none of them mention any of the other women's colleges, which were founded around the same time. Tuke does mention Queen's college, but only in the barest capacity. More to the point, none of these works suggests why the women's colleges were finally able to be successful.

Contemporary sources do not fare any better. There are several works on the subject of the founding of the women's college in England; however, none of them seems to mention the reasons why the colleges were successful. In addition, almost none of them seem to deem Bedford College significant in the history of the establishment of women's colleges. At most, Bedford is seen as a footnote, passed over for the more illustrious history of the far better known Girton College. Educating Women: Cultural Conflict and Victorian Literature by Laura Morgan Green erroneously put Bedford College in the same boat as Queen's College, describing it as an institution whose sole purpose was to train girls and young women to become governesses. ${ }^{6}$ In her comprehensive work on women's education in England, No Distinction of Sex? Women in British Universities, Carol Dyhouse does not begin her

\footnotetext{
${ }^{6}$ Laura Morgan Green, Education Women: Cultural Conflict and Victorian Literature, (Athens: Ohio University Press, 2001), 11-12.
} 
narrative until $1870 .^{7}$ Moreover, while she does cover the foundations and early struggles of the major women's college, she mentions Bedford, and Queen's for that matter, only in passing. In addition, Dyhouse fails to discuss the possible causes of the initial success of the foundation of the colleges, but does a superb job in cataloguing how the colleges, with the exception of Bedford and Queen's, were able to overcome their early struggles. Other works, such as Victorian Education and The Ideal of Womanhood, by Joan N. Burstyn, The Higher Education of Women in England and America, 1865-1920 by Elizabeth Seymour Eschbach, Women and Education, 18001980 by Jane Martin and Joyce Goodman, and Bluestockings: The Remarkable Story of the First Women to Fight for an Education by Jane Robinson also fail to mention or credit any significance to Bedford College. ${ }^{8}$

Not all contemporary sources dismiss Bedford College. The College itself has published a few works in recent years that attempt to delve into the college's history. However, these works also suffer fatal flaws. Both Educating Women: A Pictorial History of Bedford College, University of London, 1849-1985 by Linna Bentley (published in 1991) and Bedford College: University of London: Memories of 150 Years, edited by J. Mordaunt Crook and published in 2001, were written in the same spirit as Tuke's work in 1939. The publishing of Bentley's work coincided with the merging of Bedford College and Royal Holloway in 1985 to create the Royal Holloway Bedford New College, and the chapter on the early years of the college is a

\footnotetext{
${ }^{7}$ Dyhouse, 1-25, passim.

${ }^{8}$ Joan N. Burstyn, Victorian Education and the Ideal of Womanhood, (London: Croom Helm, 1980); Eschbach; Jane Martin and Joyce Goodman, Women and Education, 1800-1980, (London: Palgrave, 2004); Jane Robinson, Bluestockings: The Remarkable Story of the First Women to Fight for an Education, (London: Viking, 2009).
} 
repetition of Tuke's work. Crook's work was compiled as a celebration of the college's 150th anniversary, and is an anthology of essays written by several of the college's alumni. ${ }^{9}$ While most of the book falls out of the scope of this thesis, the chapter written on the foundation and early years of the college is within the scope but, again, is little more than a rehashing of Tuke, and a rehash without substantial scholarly research at that. To be fair, neither of these books is attempting to be particularly scholarly and repeating Tuke's history might be overlooked if the original work had been less flawed. Furthermore, nearly all of the contemporary sources that happen to mention Bedford College reference Tuke's work rather than referencing original research.

In the process of collecting her data and compiling her own research into the college, as noted earlier, several documents were misplaced by Tuke, either in whole or in part. While her work contains reprints of some key letters, and does a fantastic job of compiling data on students, faculty, finances and other subjects in helpful bar graphs, she rarely cites her sources. This can be particularly frustrating when she references an especially juicy quote and fails to mention its origin. All of this makes any original research on Bedford College problematic at best, as does the scarcity of personal writings from the founder herself.

Unlike most women of the Victorian Era, Reid did not keep a journal or a diary. What little we do have on her thoughts on women's education come from a

\footnotetext{
${ }^{9}$ Linna Bentley, Educating Women: A Pictorial History of Bedford College, University of London, 1849-1985, (London: Alma Publishing, 1991); J. Mordaunt Crook, ed., Bedford College: University of London: Memories of 150 Years, (Egham: Royal Holloway \& Bedford College, 2001).
} 
scattering of letters saved by her friends and others, the words of those who helped her to establish her new college, and probably most significantly, her prospectus for this pioneering institution as well as the Trust she established for its administration following her death. The letters and reminiscences, along with the prospectus, her will and her drafting of the Trust for the College help provide insight into Reid's reasons for founding a college for women. In particular, her letter to Jane Martineau and Elizabeth Ann Bostock, future members of the Board of Trustees of Bedford, in which she asserts, "that a College for Women or something like it, has been [her] dream from childhood," offers a great deal of insight into Reid's ambitions. She goes on to state that though she had made several attempts in the past to launch such a venture all had failed. Unfortunately, there are no records of her longtime desires to open a women's college or of any previous attempts she might have made. Other insights into Reid and her dedication to opening a college for women can be gained through the letters sent to her by her friends and colleagues, especially those of Bostock, Martineau, and Eleanor E. Smith, the first members of the Reid Trustees. All were close friends of Reid and there are quite a few letters between them, especially between Reid and Bostock. Many of these letters discuss the foundation of the college and the problems faced in its early years, including what courses should (and should not) be taught, the granting of scholarships and financial troubles. More insights into Reid and the foundation of the college can be found through Reid's correspondence with Henry Crabb Robinson along with excerpts from his journals. The well-known writer was a friend of Reid's as 
well as an early financial contributor of the college. Robinson frequently mentions Reid in his journals, and offers several insights into her character and motivations.

Additionally, there is an abundance of records about the business of Bedford College, which are currently held in the Royal Holloway Bedford New College archives, and have been meticulously preserved and catalogued. Nearly all of the records on which this thesis is based come from the Bedford archives, save for a handful of documents that are reprinted in Tuke's book, as well as in a few other published work and documents were acquired from the archive including various notes and correspondences of the Lady Visitors of the college, as well as several accounts of students, scholarships and minutes of the annual general meetings. Unfortunately, the lack of access to other sources has limited the scope of this thesis to the foundation of the college, the creation of a general council, securing investors and professors and the establishments of the Bedford Junior School and the Reid Trust. This work will only marginally examine the individuals of Bedford including professors, students, and Lady Visitors and will not focus on their daily activities or their motivations behind associating with the College.

Chapter One of this thesis will focus on the outside influences that created the context for the founding of Bedford College, beginning with safe and respectable movements such as the Abolitionist, as well as women's involvement in charitable institutions and benevolence societies. As they entered into the public sphere and the world of politics, the women of these acceptable movements gained energy that would carry through to the establishments of Queen's and Bedford and the first stirrings of 
the women's higher education movement. This chapter will also examine the ways in which the middle class began to campaign for better education for their children, sons and daughters alike. Not only did these circumstances affect the foundation of Bedford College, they also influenced the state of education as a whole as several reforms were made concerning the overall quality of the education of the youth of the nation. This chapter will also look at the foundation of Queen's College, established only eighteen months before Bedford as an extension of the Governesses Benevolence Institution, and examine what effects its establishment had on the founding of Reid's College.

The second chapter will look more closely at Bedford College itself, its founder and its foundation, and its first twenty years, the years before Girton College opened in association with Cambridge University. According to Tuke, Elisabeth Reid did not have "particularly subversive" ideas about education, nor was she especially radical in her views on women receiving an education. Instead, her goal was to educate women so that they might become better mothers to their children and better wives to their husbands. ${ }^{10}$ In order to understand the motivations behind this "dream," Reid's early life will be examined, focusing on her childhood, religious believes, and brief married life. This chapter will also analyze the foundation of the college and all of the minute details required in such an undertaking, including funding, religious influences, courses and professors. Unlike the colleges of Girton and Somerville (associated with Cambridge and Oxford, respectively), Bedford was not associated with an established University, even in name until much later, and unlike Queen's

\footnotetext{
${ }^{10}$ Tuke, 13-14.
} 
College, it did not have royal patronage or support from the Anglican Church.

However, and most significantly, Bedford did have the support of the women's higher education movement, the beginnings of which this chapter will also examine.

Chapter Three will look beyond the first twenty years of Bedford and focus on how the college operated during and after the establishments of the women's colleges at Cambridge and Oxford. Emily Davies founded Girton College at Cambridge in 1869, and the founding of Newnham College in 1871 quickly followed. Oxford was a bit slower to accept the notion of women in higher education, with Lady Margaret Hall and Somerville College established nearly a decade later. This chapter will discuss how Bedford College influenced the new colleges, and how they in turn, influenced Bedford. Additionally, this chapter will consider the University of London's decision in 1878 to confer Bachelor of Art degrees upon women and the impact this new development had on the students and the curriculum of Bedford. Finally, it will touch on the opposition that developed in response to the growing momentum and success of the women's higher education movement. In 1900, the University of London became a teaching institution, whereas before it had only been a degree awarding body, and Bedford College was incorporated as one of the University's constituent college, ending one chapter of the institution and beginning another.

Readers will notice that each Chapter, as well as the introduction and the conclusion begin with a few lines from Alfred Lord Tennyson's poem The Princess. ${ }^{11}$ Tennyson, who was friends with F.D. Maurice wrote and published the poem in

\footnotetext{
${ }^{11}$ Alfred Tennyson, The Princess and Maud, vol. 4 of The Works of Alfred Lord Tennyson (London: Macmillan, 1908), 10-137, passim.
} 
response to the founding of Queen's College. Though critics are somewhat divided as to where Tennyson's sympathies lay concerning women in higher education, the majority opinion seem to feel that while the poet was supportive of a progressive view of higher education for women, he nonetheless found it convenient to subordinate his view to the dictates of Victorian Society. ${ }^{12}$ Questions about his sympathies aside, The Princesses is a lighthearted poem reminiscent of a Shakespearian comedy, in which a Prince is confused and angered when his betrothed runs away in the middle of the night in order to attend school rather than marry him. The Prince, along with his two friends decided to disguise themselves as women and enter the school, so that he can better understand why the Princess might want to be educated rather than marry him. In the end, the Prince's ruse is discovered and following a battle of words and swords, the Princess is convinced to return to his kingdom as his wife. Although it is certainly possible to attempt to discern Tennyson's true feeling on women in higher education through his poem, for the purposes of this thesis, The Princess will simply serve as a way to introduce each chapter with a few clever lines that may or may not offer insight to popular views on the topic.

\footnotetext{
${ }^{12}$ Alisa Clapp-Itnyre, "Marginalized Musical Interludes: Tennyson's Critique of Conventionality in The Princess," Victorian Poetry, Volume 38, No. 2 (Summer, 2000), 227-230.
} 
Chapter One: "Above the Duties of Her Station":

The Increasing Presence of Women in the Public Sphere, 1800-1849

O lift your natures up:

Embrace our aims: work out your freedom.

Girls, Knowledge is now no more a fountain seal'd:

Drink deep, until the habits of the slave,

The sins of emptiness, gossip and spite

And Slander die.

-The Princess, Act I

When Elizabeth Jesser Reid opened the doors to Bedford College for Women in the fall of 1849 , the idea of women stepping outside of the private sphere of the home into the public world of politics and the market was still relatively new. While the home and the family had often been considered the domain of women in the past, the idea of keeping women out of the public arena in order to protect their virtues took on increased importance in England following the initial phase of the Industrial Revolution. Throughout most of the nineteenth century, women, especially those of the middle and upper classes, were expected to live quiet lives within the safety of their homes, spending their days caring for their husbands and children, running the household and providing a moral sanctuary away from the evils of the outside world. Along with these new ideas of domesticity came changing ideas on the education of children. ${ }^{13}$ This chapter will focus on these new ideas of education and the movements that created the social ferment that would eventually lead to the foundation of Bedford College and the establishment of the women's higher education movement.

\footnotetext{
${ }^{13}$ Leonore Davidoff and Catherine Hall, Family Fortunes: Men and Women of the English Middle Class, 1780-1850 (London: Routledge, 1988), 64-65.
} 
Prior to the early nineteenth century, boys and young men of upper- and middle-class families often received education through the university level, while girls were rarely educated beyond the basic skills of reading, writing and simple arithmetic, and many did not even receive this much. Instead, girls from the upper and middle classes of society were taught the fundamentals necessary to become good wives and mothers: sewing, dancing and conversing, as well as a small amount of education concerning household management. This level of education might have sufficed in centuries past for upper-class women who had been required to do little, but it did not suffice for the women of the nineteenth century, who were often in charge of running their homes and supporting their husband's careers, and sometimes were also responsible for the education of their children.

As Joyce Burstyn notes, the demand for satisfactory education for both women and children came from "those who had risen in social position and felt the inadequacy of their own education to prepare them for their new life." ${ }^{14}$ Many of the new professional middle class began to call for better schooling for their children, so that their sons would be trained for their future jobs and their daughters taught proper conduct for their future families and husbands as well as basic household management skills. The attention of this group was thus focused on the governesses, as they were often the first, or only for many girls, introduction to education for middle-class children. The standards and qualities of governesses had declined sharply in the 1830s and 1840s, and in an effort to advance their own position in society, the middle class

\footnotetext{
${ }^{14}$ Burstyn, 18-23.
} 
began to demand greater sophistication from those charged with educating their children. At the same time, many women of this new rising class, more so than men, were recognizing their own lack of education.

Combined with the endless amount of inactivity that now typically filled their day, this new focus within education caused women to venture outside the sanctity of their home, either to involve themselves in social movements or to attempt to educate themselves. It is in this combination of developments that the motivations for Reid's establishment of Bedford can be found. Unlike Emily Davies and her founding of Girton College, which will be examined in the next chapter, Reid had no aggressive motive behind her institution. She did not found Bedford with the desire to challenge social or gender boundaries nor was she intent on challenging an oppressive system against women. Instead, Reid wanted to help educate women so that they would become better wives and mothers, and be able to manage their households better.

Many women began slowly to push at the social boundaries which dictated they be kept in the home and away from the "amoral" outside world. This was achieved through participation in various religious charitable and philanthropic organizations, and eventually through their involvement in "safe and respectable" movements, the most important and substantial of which was the Abolitionists movement, especially since it was the first major movement in the nineteenth century in which women played an essential role, beyond a supportive or auxiliary position. Women's roles in the anti-slavery movement in England included giving lectures against the evils of the institution, gathering signatures for petitions to send to 
Parliament and organizing boycotts against slave-made products. ${ }^{15}$ Beyond the physical work they contributed, women also lent a certain amount of creditability and temperance to the movement simply by being female. They brought a sense of morality to the movement, as well as the impression of civility and restraint. Thus it was the inherent goodness of women that allowed them to join this and similar movements while still maintaining proper social behavior.

Beyond this movement, there were other socially acceptable ways in which women became involved in the public sphere, the most predominate of which were charitable organizations. One such group was the Governess' Benevolence Institution (GBI). Founded in 1845 under the leadership of Frederick Dennison Maurice, this Institution was established with the intention of providing governesses with financial relief during unemployment or old age and sufficient training for those who served upper-class families. ${ }^{16}$ The foundation of this institution was the culmination of women's slow entrance into the public sphere and the start of the middle class desiring a better education for themselves and their children. As previously noted, the majority of the focus of the middle class was aimed at the governesses and their lack of adequate training. Three years after its foundation, the GBI established Queen's College, also under the guidance of Maurice. The College's mission was to train girls and young women to become better governesses for middle- and upper-class families. The foundation of Queen's was an important stepping stone for the soon-to-follow

\footnotetext{
${ }^{15}$ Karen I. Halbersleben, “'She Hath Done What She Could': Women's Participation in the British Antislavery Movement, 1825-1870" (unpublished PhD diss., University of New York at Buffalo, 1987), 20-29, 108-110.

${ }^{16}$ Burstyn, 23.
} 
establishment of Bedford College, and Maurice and his supporters would help to start the women's movement for higher education alongside Elisabeth Reid and her supporters. Both Colleges were invaluable to the successful foundation of the women's colleges of Cambridge and Oxford that would follow, though Bedford would quickly prove to be the center and the driving force behind women in higher education.

The idea of women in higher education was certainly not new to the citizens of England. During the time of the Tudors, upper-class women and girls, such as Queen Elizabeth and Lady Jane Grey, were given a classical education, and were not considered any less "womanly" for it. The standards for girls and women's education were lowered in the century after the English Reformation, despite the best efforts of writers and intellectuals like Bathsua Makin, Mary Astell and Daniel Defoe. Astell herself had proposed the idea of a women's college in 1694, but the notion was dismissed on the grounds that such an institution would too closely resemble a Catholic nunnery. Defoe argued for the academic education of girls to equal that offered to boys. ${ }^{17}$ Standards and views of women gaining a more advanced education remained low in England until the late-seventeenth and early-eighteenth centuries. American historian Elizabeth Seymour Eschbach commented on this turn of events in her work The Higher Education of Women in England and America. She noted that many outspoken literary figures in both America and England wrote on the subject, "citing the intellectual deprivation of women and urging society to consider the

\footnotetext{
${ }^{17}$ Eschbach, 10.
} 
benefits of filling this need." 18 The push for higher quality education for girls and women came in waves in America, with each crest following a significant social upheaval, such as the Revolutionary War, the War of 1812 and the American Civil War. More than likely the surge in advocacy for women's education came from a surplus population of women following these wars, as the number of men significantly decreased. Halfway through the century girls and young women in America saw a surge in access to higher education following the Civil War during a movement known as Republican Motherhood. Yet England saw no such events in their country in the nineteenth century that would help to explain the push for better education for girls and women. Instead, England was facing the beginnings of the peak of the Industrial Revolution, which would result not only in an massive increase in population, but also in the creation of a new professional middle class, who would lead the charge in campaigning for women to be able to access a higher education. ${ }^{19}$ This campaign was born through the middle class's lack of adequate education to prepare them for their new station in society, and their desire for their children to have a better life and education than themselves.

In their groundbreaking work, Family Fortunes: Men and Women of the English Middle Class, authors Leonore Davidoff and Catherine Hall wrote about the changing ideas of domesticity that came with the onset of the Industrial Revolution in England. Among several other changes occurring at this time, Davidoff and Hall

\footnotetext{
${ }^{18}$ Ibid, 9-10.

${ }^{19}$ Burstyn, 20-35; Christine De Bellaigue, Educating Women: Schooling and Identity in England and France, 1800-1867 (Oxford: Oxford University Press, 2007), 20-27.
} 
discussed the evolving state of education, and the differences between the education received by boys, and that received by girls. Nearly all the children of the middle-class at this time began their education at home, at the hands of either their mother or a hired governess, but while nearly all boys of the upper and middle classes were also sent to day school, only a small handful of girls from the upper class were given the same opportunity. As children grew and reached their middle teens, girls would stay at home, while boys would venture into the world outside the home, by either going to work with their fathers as apprentices, or if the family had enough money, by attending secondary schools followed by university. ${ }^{20}$ No such form of higher education was available in England for the girls and young women of any class. Of course, for the children of the lower classes, little education was available at all. Not only did both parents work, but the children of the family were often also required to work to provide income for their family.

However, there was a plethora of other reasons beyond a family's monetary worth as to why women might be denied access to higher forms of education. Historian Joan Burstyn argues in her work Victorian Education and the Ideal of Womanhood that access to education was strictly guarded for the preservation of society. She claims the Victorians saw education as a means of social control, and as a way to limit individual betterment, especially where the lower classes and women were concerned. Emphasis on class only applied to the male members of society, as

\footnotetext{
${ }^{20}$ Laura Fasick, “The Reform of Women's Education in Tennyson's The Princess and Gilbert and Sullivan's Princess Ida," in Gender and Victorian Reform, ed. Anita Rose, (Cambridge: Cambridge Scholars Publishing, 2008), 27-30.
} 
women and the lower classes were often both thought of in the same terms with regard to education. ${ }^{21}$ Noah Webster summed up the widespread upper-class view towards women in education when he claimed that female education was good, "if it rendered the ladies correct in their manner, respectable in their families and agreeable in society, [but] that education is always wrong which raises a woman above the duties of her station." 22

Burstyn further underscores the prevalence of this sentiment, stating that while the lower classes were given a rudimentary form of literacy, they were primarily taught to know their place in life, and that "social control was the predominate theme of Victorian education for women of all classes." ${ }^{23}$ Much like the lower classes in general, middle-class women were given only as much education as was deemed necessary for them to perform their role in society adequately. The separate spheres ideology, most effectively outlined in Davidoff and Hall's work, dictated that while men moved and thrived in the public world of politics and the market, women stayed in the sheltered private world of the home and domesticity. ${ }^{24}$ Thus, while men needed to possess a higher education to be able to navigate the difficult waters of the Victorian political world successfully, it was seen as unnecessary and wasteful to

\footnotetext{
${ }^{21}$ Burstyn, 11-15.

${ }^{22}$ Eschbach, 18.

${ }^{23}$ Burstyn, 11.

${ }^{24}$ In her work, “'Uneven Developments': Women's History, Feminist History and Gender History in Great Britain,” Jane Rendall appreciates Davidoff and Hall's approach, but cautions historians against apply their methods to different locations, as "those constructions of masculinity and femininity...change over time." However, as this thesis falls under the time period of Davidoff and Hall's work, such caution will be minded though it does not necessarily apply. Jane Rendall, "'Uneven Developments': Women's History, Feminist History and Gender History in Great Britain," in Writing Women's History: International Perspectives, eds. Karen Offen, Ruth Roach Pierson and Jane Rendall (Bloomington: Indiana University Press, 1991), 52.
} 
endow the same sort of education upon women, who would not use it towards any sort of employment. ${ }^{25}$ Instead, women of the upper class were expected to fill their days with household management and leisurely pursuits. Yet Burstyn argues that with the development of the professional middle class, attempts were made to professionalize the traditional women's work of family care, which would result in a drastic change in the character of the women's sphere. Those who pushed for this change claimed that women needed a higher form of education and more training to be successful in their roles of wife and mother. Women were not only expected to run the household efficiently, but also were meant to "prepare their children to enter school, teach them to live upright, moral lives, and organize and run charitable institutions," all of which required substantially more training then they were being given. ${ }^{26}$

In order to appreciate the difficulties these women faced in managing and running their households, it is first necessary to understand exactly how inadequate their education was in this period and how it compared to the education of boys and men. Fathers ensured their sons received a proper schooling so that they would be adequately prepared to eventually take over their own business, however, they saw no need to take the same actions with their daughters. In the Victorian household of the upper- and upper-middle classes, young girls were dependent upon their brothers for an education, or more accurately, upon their parents' willingness to allow them to observe the lessons given to their brothers at home. ${ }^{27}$ However, when the time came

\footnotetext{
${ }^{25}$ Davidoff and Hall, 64-65.

${ }^{26}$ Burstyn, 18-22.

${ }^{27}$ K.D. Reynolds, Aristocratic Women and Political Society in Victorian Britain, (Oxford: Clarendon Press, 1998), 93-95.
} 
for these young men to leave the household and further their education elsewhere, the schooling of the girls and young women of the family effectively came to a halt. In her scathing critique of the Victorian education system The Higher Education of Women, author, women's rights activist and eventual co-founder of Girton College for Women at Cambridge, Emily Davies comments on the situation.

Parents are ready to make sacrifices to secure a tolerably good and complete education for their sons; they do not consider it necessary to do the same for their daughters. Or perhaps it would be putting it more fairly to say, that a very brief and attenuated course of instruction, beginning late and ending early, is believed to constitute a good and complete education for a woman. ${ }^{28}$

Davies, along with a handful of other writers of the time, protested the inadequate education given to women, particularly in light of the schooling men of the time received. She noted that boys' education began at a young age, and continued steadily until they reached adulthood, leaving school at the age of sixteen or eighteen and continuing on to either a technical course of training for business or on to a University. Upon completion of such schooling, boys would enter into the wider world, where a "larger education [was] supplied by the business of life." 29 Girls on the other hand, had no such structure in their education. If a girl had been fortunate enough, in terms of her parents' wealth and attitude, she might have been sent to a boarding school to continue her paltry education after the departure of her brothers. Generally though, the English boarding schools of the late eighteenth and early nineteen centuries were little more than finishing schools, and fell woefully short of

\footnotetext{
${ }^{28}$ Emily Davies, The Higher Education of Women, (London: Alexander Strahan, 1866), 39.

${ }^{29}$ Ibid, 39-40.
} 
the academic standards seen at either the schools for boys, or the girl's academies across the Atlantic in America. ${ }^{30}$ While the upper classes may have been initially satisfied with this level of education for their daughters, it was the middle class who pushed for better education of their children, including their daughters, so that they could succeed in either the public or private spheres. In their rapid rise to this newly created class, many felt ill prepared for the society of which they were now members. Parents who desired their children to be better prepared than they themselves were campaigned for higher quality education to ensure their children's future. This was also the goal of Elisabeth Reid and the other founders of Bedford, in their attempts to educate girls and young women so that they might become better wives and mothers, which will be discussed further in the next chapter.

While Eschbach asserts the English mentality preferred the passive alabaster lady outlined by the likes of George Gregory and James Fordyce, Davies insists there was a far more practical explanation behind the discontinuation of girls' education: money. ${ }^{31}$ Davies comments that she knew of few fathers who would have been willing to spend any sort of hard-earned income on education for their daughters when they would have been unable to utilize such a gift in the same way as a son would have. However, as Elaine Kaye points out, during the first half of the Victorian era, a slow but steady surplus of women over men was forming, and men were waiting longer and

\footnotetext{
${ }^{30}$ Eschbach, 25.

${ }^{31}$ George Gregory (1754-1808) was an English writer and preacher who was best well known for his work Essays, Historical and Moral where he wrote on, among other topics, the proper place of women in the home and in society. James Fordyce $(1720$ - 1796) was a clergyman best known for his collection of sermons published in 1766 entitled Sermons for Young Women. Eschbach, 18-35; Vivian Jones, Women in the Eighteenth Century: Constructions of Femininity, (New York: Routledge, 1990), 25-26, 79.
} 
building more capital before they decided to marry. This presented a difficult dilemma for both women, and their families. Victorian propriety frowned on women living without a male head of household, even if they somehow had the means to do so. Therefore, women were obligated by society to remain at home and live off the wages of their parents until they married, which often caused a financial hardship for middleclass families. Furthermore, women were also socially prevented from attaining occupations themselves, or from monetarily contributing to their family. ${ }^{32}$

During this time, the only socially acceptable occupation for women, beyond that of marriage of course, was as a governess, which will be discussed in more detail below. Men were allowed and even expected to leave their familial home in order to obtain employment and acquire both status and capital before they entered into matrimony. This practice was a departure from traditional marriage customs of centuries past, in which men were not considered to have reached full adulthood until they took a wife. ${ }^{33}$ Only after they had married had they set about gaining status and capital. In the new era of the Industrial Revolution however, men could be considered adults without entering into marriage, which meant that many were waiting for longer periods of time before they entered into that phase of their lives, ultimately forcing women to wait as well. These women, who were neither allowed to attend a higher educational institution (which was not even an option that existed for women until the

\footnotetext{
${ }^{32}$ Elaine Kaye, A History of Queen's College, London 1848-1972, (London: Chatto \& Windus, 1972), 13-14.

${ }^{33}$ Mary Poovey, Uneven Developments: The Ideological Work of Gender in Mid-Victorian England, (Chicago: The University of Chicago Press, 1988), 8-15.
} 
mid-1840s at the earliest), nor allowed to seek employment, found themselves facing endless days filled with little to occupy their time or their minds. ${ }^{34}$

This predicament was raised and addressed several times by Davies, who points to this lack of mental stimulation as a prime reason for allowing women to access higher education. She identifies only a limited number of activities that were deemed socially acceptable for women's participation: needlework, cookery and the care of children. ${ }^{35}$ It should be noted, however, that Davies neglects to mention that women were permitted to contribute and participate in charitable institutions and benevolent societies. While there are a few reasons why Davies might have left these activities out of her list of acceptable occupiers of time, the most logical explanation for their absence may be that their inclusion would have weakened her overall argument. Such places and groups offered women a way to interact safely in the public sphere, or at least the semi-public sphere, while maintaining social suitability and did not always require them to possess an education higher than they would have received at home. Still, these activities aside, Davies stresses that there was very little for women to do within the home, a fact of which many fathers were no doubt aware. However, as she points out, this was not seen as a hardship by men, who wished "they had a little less to do themselves, and [could] imagine all sorts of interesting pursuits to which they might betake themselves if only they had a little more leisure." ${ }^{36}$ Davies

\footnotetext{
${ }^{34}$ Martin and Goodman, 62-65.

35 Davies, Higher Education, 47.

${ }^{36}$ Ibid, 47.
} 
further goes on to state that men believed it was the choice of women to remain idle, that they preferred such a state; otherwise, "they would find something to do.",37

This statement is difficult to digest for a number of reasons. First, women were expected to be content in remaining firmly entrenched in the private sphere, maintaining little to no prolonged contact with the harsh realities of the public world, which was generally considered to be far too chaotic for women's delicate sensibilities. Second, the early nineteenth century was, according to Davies, "an age in which idleness [was] accounted disgraceful." 38 However, historian K.D. Reynolds asserts that this was not always the case, and that the image of the non-working female as the perfect embodiment of the aristocratic female was created during the Victorian period. The female who was able to acquire leisure could believe herself to have acquired both social status and the ideal of femininity. Yet Reynolds does note that as the period went on, the more hostile observers began to create new equations between the aristocracy and this new idea of femininity. She claims that the aristocracy, and women by extension, began to be equated with the least desirable of the traits of the life of leisure: laziness, frailty, corruptibility, frivolity and interest in the trivial especially fashion and sexual weakness. ${ }^{39}$

While Davies does adequately portray the frustrations felt by many young women of the period, her assertions that men believed women chose to be idle and refused to find something with which to occupy their time are difficult to believe. One

\footnotetext{
${ }^{37}$ Ibid, 49.

${ }^{38}$ Ibid, 50-51.

${ }^{39}$ Reynolds, 16-23.
} 
of the more striking points she makes in her work is the amount of discontent the "modern girl" felt in this time of idleness. Davies notes that this modern girl was fully aware of the new disdain directed towards those who lived a life of idleness and leisure, "that people who do nothing are unfruitful fig-trees which cumber the ground. $" 40$ To her, the accusations were particularly cruel, especially in light of the fact that there was very little many women could do to ward off idleness. "The modern girl is bidden to look around her - to do the duty that lies nearest - to teach in the schools, or visit the poor - to take up a pursuit - to lay down a course of study and stick to it. She looks around her, and sees no particular call to active exertion." ${ }^{41}$ The situation was further exacerbated if there was more than one "adult" female in the household, as was more common than not. There were only so many duties to be done, which might have been completed by either their mother or an elder sister. This lack of activities to fill the day was one reason for women's departure from the home and their entrance into the public world, albeit by socially acceptable means through safe and respectable movements and involvement in charitable institutions. Eventually, the ennui of home life would also lead some women to attend the lectures and reading groups held at the home of Elisabeth Reid and some to enroll in classes at her new college, which will be examined in the next chapter.

Davies cites other impediments faced by these girls who were given so few prospects in their lives. It was possible that the girl "had no vocation for philanthropy...or she lives in a village where the children are better taught than she

\footnotetext{
${ }^{40}$ Davies, Higher Education, 51.

${ }^{41}$ Ibid, 54-55.
} 
could teach them; and the poor are already too much visited by the clergy-man's family." Furthermore, "so long as she is quiet and amiable, and does not get out of health, nobody wants her to do anything." ${ }^{, 42}$ For such girls, there were little to no possibilities before her, other than marriage, where she would most likely be faced with the same sort of monotony she experienced in her parent's household. In this abysmal and depressing atmosphere, it is unsurprising that more and more women of the Victorian era began to push the boundaries of socially acceptable behavior, and venture further and further into the previously forbidden world of the public sphere. There are a number of reasons why women began quietly to challenge social boundaries, including boredom within the private sphere, the creation of a new middle class that desired to distance itself from the poverty of the lower classes and the immorality of the upper classes and finally, the desire of middle-class women to improve their minds, whether through education or experience, so that they might be better able to education their children.

In fact, as the century went on, more women began pushing at the edges of the public sphere bubble and became involved in a number of different causes and movements. These included the abolitionist movement, and universal suffrage and enfranchisement, as well as a number of charities and kinds of philanthropic work. These women found ways to work within the strict moral codes of society while striving towards the betterment of themselves and their fellow citizens. Though such activities provided women some measure of fulfillment in their lives, many were

\footnotetext{
${ }^{42}$ Ibid, 55-56.
} 
unsatisfied with simply participating in charity work and looked for ways to engage their minds. By entering into the public sphere, these women challenged strict boundaries, some more radically than others did, which would eventually result in women entering areas of society never before deemed acceptable, not the least of which was higher education. However, before discussing how the restrictions imposed by society were tested, it is first necessary to understand how those lines and such a society evolved in the first place.

In their work, Family Fortunes: Men and Women of the English Middle Class, Leonore Davidoff and Catherine Hall thoroughly discuss the formation of the British middle class and the social and gender relations and conflicts that rose at the same time, as well as what separated this new social class from the lower classes and the aristocracy. The provincial middle class as we now know it developed in the late eighteenth and early nineteenth centuries, in the chaotic decades that witnessed the French Revolution, the Napoleonic Wars and the onset of the English Industrial Revolution. These events drew out groups with common interest, those suffering from the horrors of war, those experiencing the fallout of the breakdown of the old Poor Laws, and those who felt the pressure of a growing population of wage laborers, and banded them together. ${ }^{43}$

While the aristocracy and lower classes also experienced these events, the lack of religious uniformity within their ranks, along with their property holding and their strong moralistic sense of values set them apart. However, regardless of the mismatch

\footnotetext{
${ }^{43}$ Davidoff and Hall, 18-23.
} 
of Tories and Whigs, rural and urban, farmer and professional, or Anglican and nonconformist, the common thread that linked the newly formed middle class all together was their dedication to the construction of a rigorous moral code and the preservation of the safe environment of the home in which to practice their way of life. ${ }^{44}$ More than anything else, Davidoff and Hall stress the new provincial middle class "were at the heart of the revivals that swept through all [religious] denominations" of this period, and cannot be understood or appreciated without first comprehending their religious outlook. ${ }^{45}$ Religion was at the very core of the middleclass; it dictated how they acted in the public world, the morally correct way to run their homes, how they ought to raise their children, and, perhaps most importantly, the proper roles for both men and women. Education often helped to strengthen this core, especially in the early nineteenth century. While education would be seen as having the potential to undermine religion later in the century, at this point education was viewed as a way to support the moral code of the middle class. The future establishment of Bedford was no different, as the primary goal of Reid's college was not to encourage women to flout social propriety, but to help them become better wives and mothers within socially acceptable middle-class boundaries.

Religion was also one of the key ways in which the middle-class differentiated themselves from those above and below them in the social order. Traditionally, the aristocracy and the upper class based thier power upon lavish displays and consumption of wealth, whereas the new middle class of post-Industrial Revolution

\footnotetext{
${ }^{44}$ Davidoff and Hall, 22-27.

${ }^{45}$ Ibid, 21.
} 
England based its power upon its moral superiority and stressed domestic moderation. ${ }^{46}$ In its efforts to distance itself from the immoral over-indulgence of the aristocracy, the middle class embarked on creating a proper religious and moral home in which its members would spend their lives and raise their children. Despite the desire of members of the middle class to separate themselves from the other classes, it is equally important that they not be seen as a singular block. This newly formed class contained an assortment of professions, religious denominations and backgrounds that were often at odds with each other. This dedication for the creation of a strong moral life is also present in the foundations of Bedford and Queen's Colleges, though Elisabeth Reid and F.D. Maurice each had different methods to achieve this goal, as will be discussed further below and in the next chapter.

Along with this new rising class came an upsurge in moralistic charity work, which both men and women performed by any number of means, the most common of which was participation in benevolence institutions and charitable societies, each with its own specific cause. While a great many of these groups consisted only of men, with women acting in an auxiliary role, some, such as the Anti-Corn Law League were comprised of both genders. In addition, there were a significant number of charitable societies founded by, run by and comprised solely of women. Before any of these movements arose however, both men and women joined forces to eradicate what they saw as a mortal sin.

\footnotetext{
${ }^{46}$ Philippa Levine, Feminist Lives In Victorian England: Private Roles and Public Commitment, (Oxford: Basil Blackwell, 1990), 80-85.
} 
Women's organizations aimed toward the goal of abolishing slavery began to appear in the first few decades of the nineteenth century. While the official national anti-slavery societies in England were controlled by men, groups like the Bristol and Clifton Ladies Emancipation Society, the Women's Emancipation Union, and the Kensington Ladies Debating Society in England and the Edinburgh Ladies Emancipation Society in Scotland still managed to wield a significant amount of power. ${ }^{47}$ These groups were able to do so because abolition was a primary concern of the Religious Society of Friends even before the cause was adopted by the Evangelicals. The lack of a gendered division amongst the Friends meant Quaker women had traditionally been involved in causes and movements. "Quaker girls were taken to public anti-slave meetings... and Quaker children playing at being adults included 'going to anti-slave meetings' among the adult activities views as a natural part of both a father's and mother's world."48 Just as the importance of religion is essential to understanding the beliefs and motivations of the rising middle class, it is equally important to understand the linkage between religion and the abolitionist movement, and the particular draw this movement had for women.

As stated above, women were initially welcomed into the abolitionist movement in auxiliary roles because of the moral and religious advantage they brought to the cause. The presence of women in the movement validated it as a religious movement dedicated to the eradication of a mortal sin, and not a group intent

\footnotetext{
${ }^{47}$ Catherine Hall, Keith McClelland, and Jane Rendall, Defining the Victorian Nation: Class, Race, Gender, and the Reform Act of 1867, (Cambridge: Cambridge University Press, 2000), 13-16. ${ }^{48}$ Lilian Lewis Shiman, Women and Leadership in Nineteenth-Century England, (New York: St. Martin's Press, 1992), 46.
} 
on disrupting an established institution that was the source of wealth for many of England's upper class. Though women were not the only reason Abolitionism was seen as a moral religious movement and not as a potential means of social upheaval, their presence brought a measure of creditability to this crusade.

The early 1800 s and the 1830 s in particular, were a high point in the abolitionist movement's fight to end the Atlantic Slave Trade and abolish slavery on British soil. Abolitionism was a movement founded on the shoulders of the middleclass, whose particular ethos declared that any contribution, "no matter how small or humble" was of benefit to the greater cause of the group. ${ }^{49}$ In this way, antislavery was also a Christian movement, utilizing evangelical symbols and rhetoric. The common belief was that women were uniquely qualified to deal with issues of religion and morality. By identifying the abolition of slavery as a moral and religious movement, women were assured a place in this crusade for abolishment and a special place in society. ${ }^{50}$ During this period of religious imperatives and a society that demanded strict social and gender boundaries, anti-slavery was deemed a safe, respectable and proper movement in which women might be involved. The movement would not demand any great social upheaval and was unlikely to muster the potentially dangerous support of the lower classes. ${ }^{51}$ Middle class British women also may have been drawn to the fight against slavery, as most saw reflections of their own repressed lives in those of the slaves, especially the females. The women of the English Anti-

\footnotetext{
${ }^{49}$ Halbersleben, 2.

${ }^{50}$ Drescher, 249.

${ }^{51}$ Halbersleben, 109.
} 
Slavery movement, Quaker or otherwise, were deeply committed to this cause, even though most of them had never and would never see a black person in their lives. This movement, which had begun nearly three-quarters of a century earlier, was one of the first large-scale movements in the nineteenth century in which women played a predominate role, marking the beginning of their forays into the world of Victorian politics.

In 1823, the first Anti-Slavery Society was formed in Britain, with the goal of eradicating and outlawing slavery throughout the Empire. A male-dominated group with a small handful of women's auxiliary groups, this Society was divided into two camps, each of which had a very different notion of how to bring about the permanent end of slavery. ${ }^{52}$ The first group, the larger and predominately older faction, strongly believed in the policy of gradual emancipation and amelioration. On the other hand, the second, and generally younger and more radical group regarded slavery as a mortal sin that needed to be purged immediately. It was this second group to whose views many women, Quaker or otherwise, subscribed. Frustrated and believing that men were not taking strong enough action to end slavery, Quaker women often found themselves in conflict with their male associates. ${ }^{53}$

Some historians, including Lilian Lewis Shiman and Jane Rendall have commented on the connection between middle-class women and the African slaves, as another motivation for involvement in the abolition movement. ${ }^{54}$ Women continued to

\footnotetext{
${ }^{52}$ Halbersleben, 37.

${ }^{53}$ Shiman, 46.

${ }^{54}$ Shiman, 47-50; and Catherine Hall, White, Male, and Middle-Class: Explorations in Feminism and History, (New York: Routledge, 1992), 124-150, passim.
} 
be involved in the movement to abolish slavery worldwide following the outlawing of the practice in the British Empire, and were arguably more effective in drawing political attention to their cause than their male counterparts. In 1833, the abolitionist group, "Ladies of England" presented a petition to Parliament bearing more than 187,000 signatures, a number no male abolitionist group had ever been able to match. ${ }^{55}$ Denied any active role in the official English political arena, women were left to contribute to the process through debate and raising awareness to their cause, an area in which they excelled.

During and following the passing of the Act of 1833, women's anti-slavery societies were out in force, implementing several strategies to push their political agenda. Public lectures were an important part of the movement, used to inform both their own members and the public of the evils against which they stood. ${ }^{56}$ While these lectures managed to drum up a small amount of support, members of the women's anti-slavery societies were the most effective in gaining public interest and Parliamentary notice through their "free-produce" movement, which called for a boycott of all slave-grown products. Members of these societies traveled door-to-door in an effort to promote their controversial boycott, speaking directly to the women who were responsible for the purchases made by the household, and by doing so persuaded many men and women to join their cause. They provoked so much interest, in fact, that members of more traditional evangelical groups grew uneasy with the

\footnotetext{
${ }^{55}$ Halbersleben, 35-36.

${ }^{56}$ Shiman, 48-49.
} 
power of their influence. Wilberforce himself attempted to reduce their authority by limiting the reporting of their actions in the Anti-Slave Reporter. ${ }^{57}$

While women's voices in the anti-slavery movement may have been subdued or silenced, the amount of influence they exerted is undeniable. However, their part in the abolitionist movement is significant in another way. For most of the women engaged in the cause, this had been their first foray into the public sphere and the world of politics. Their involvement in this "safe and respectable" movement provided a foundation on which women would build a platform to assume a greater role in society in the coming century. The unprecedented enthusiasm and number of women who participated in the anti-slavery movement marked the beginning of a social ferment that would only increase in the women's movements later in the century. The momentum created by the women of Abolitionism carried forth into the campaigns for universal enfranchisement, women's suffrage and, most important to this thesis, the movement for women's higher education. Following the anti-slavery movement women's involvement in the public sphere slowly became less anomalous and more accepted among society, furthered by their participation in charitable organizations and benevolence societies.

While women were becoming more and more involved in safe and respectable movements outside the home, their categorization must be done carefully, with the intentions of the women in question and the time period kept firmly in mind. In her work Feminist Lives in Victorian England, Philippa Levine uses the terms "feminism"

\footnotetext{
${ }^{57}$ Ibid, 49-56.
} 
and "feminist" to describe "the lifestyle and activities of women activists pursuing various changes in law, custom and practice in nineteenth century England." ${ }^{58}$ While Levine is mindful of the difficulties of applying the terms anachronistically, going so far as to ask "if women can be feminists without knowing it," she nonetheless insists that these women of nineteenth century England who consciously formed groups, activities, and philosophies that deliberately intended to fight against the "gendered wrongs" of their society be called "feminists". 59 Martha Vicinus expresses similar opinions in the two collections of essays edited by her, Suffer and Be Still: Women in the Victorian Age and A Widening Sphere: Changing Roles of Victorian Women. In her introduction of the first work, Vicinus argues that the Victorian woman broke away from her "imitation... of the model of the perfect lady" through "the courageous efforts of individual women who suffered social ostracism for their beliefs. ${ }^{\circ 60}$ In her second editorial work, Vicinus further asserts that "middle-class feminism...can best be understood through the limitations a class-ordered society imposed upon women," conveying opinions comparable to Levine's on the oppressed nature of nineteenth century middle-class women, and their active fight for equality. ${ }^{61}$ According to both of these scholars, women who actively stepped outside the boundaries of proper society could be labeled a feminist.

While both scholars provide important historical insights into the mindsets of nineteenth century women activists, problems arise when their models are applied to

\footnotetext{
${ }^{58}$ Levine, 2.

${ }^{59}$ Levine, 3-13.

${ }^{60}$ Vicinus, Suffer and Be Still, "Introduction," xv.

${ }^{61}$ Vicinus, A Widening Sphere, "Introduction," xvii.
} 
the activities and intentions of Elisabeth Reid, her fellow founders and even the first students of Bedford College, beyond the anachronistic usage of the term "feminist." Levine and Vicinus both discuss the conscious decision made by these women to fight against the society that oppressed them. However, as this blanket term distorts the true motivations behind nineteenth century women's movements, other terminology should be employed. Under Levine and Vicinus' definition of feminism, it is clear that neither Reid nor anyone else connected with Bedford fell under such purview, as there is no evidence to support an active decision to establish a college for women in an effort to fight against an oppressive society. In fact, according to Tuke, Reid did not consider her actions or ideas of women in higher education to be particularly subversive. ${ }^{62}$ Furthermore, the majority of women examined by Levine and Vicinus acted at least two decades after the founding of Bedford. Rather, Reid and the other women of her College should be discussed along the same lines as the women of Elizabeth Langland's work Nobody's Angels: Middle Class Women and Domestic Ideology in Victorian England. In place of the marauding feminist, Langland describes the middleclass woman of the early nineteenth century as "a prototype for activist women who came later in the century." ${ }^{, 63}$ She goes on to caution against automatically viewing women of the time as "suffering under patriarchal social structures" as it could prevent "a picture of [women] as heroines supporting unproblematic values in the way they [dealt] with society as the issues of gender and class." ${ }^{64}$ Painting all women who

\footnotetext{
${ }^{62}$ Tuke, 13-14.

${ }^{63}$ Langland, 22-23.

${ }^{64}$ Ibid, 11.
} 
stepped outside the social and gender boundaries as "feminists" detracts from the progress made by those who acted without a "conscious decision" to protest or challenge society. Therefore, while the women of the Abolitionist movement should be commended for their decision to eradicate what they viewed as a mortal sin and for their furtherance of women in the political sphere, they should not be viewed through the same lens as Reid and the others who began the Women's Movement for Higher Education. Instead, the abolitionists should be viewed as a foil for this later movement, from a group that made a decision actively to oppose society versus a group and a college that would become the fulcrum of the women's higher education movement, almost in spite of itself and its founders.

The movement for higher education for women started slowly. As noted earlier, in 1843, the Reverend Frederick Denison Maurice helped to establish the Governess Benevolent Institution, which would ultimately create Queen's College. According to Rosalie Glynn Grylls, Maurice was "much in advance of his time, and very often out of step with it." ${ }^{65}$ Born in Suffolk in 1805, he was the son of a Unitarian minister, although his mother and sisters were devout Calvinists. He entered Trinity College, Cambridge in 1823, but was prevented from obtaining a degree due to his lack of membership in the Established Church. He migrated to Trinity Hall, where he gained a first class degree in law. Maurice then moved to London, where he was the editor of the London Literary Chronicle until 1830. Yet, he was still unresolved in his religious outlook, but "after much conscience-searching," he entered Exeter College at

\footnotetext{
${ }^{65}$ R. Glynn Grylls, Queen's College, 1848-1948, founded by Frederick Denison Maurice, (London: George Routledge \& Sons, Ltd., 1948), 4.
} 
Oxford where he read for his orders; he was ordained in $1834 .{ }^{66}$ A short time later, he was appointed a Professor of English at King's College London, and two years after that assisted in the foundation of the Governess Benevolent Institution. The goals of the Institution came to their ultimate fruition in May of 1848, when it established and opened Queen's College of London. This College had much the same goals and aspirations of the Governesses Benevolence Institution, which had established it. Girls as young as twelve could enroll in the College, which would then provide them with the training and the skills necessary to become highly sought after governesses for the members of the upper classes. ${ }^{67}$ The foundation of Queen's College was a vital and important step in the crusade for women's access to higher education and helped to lay the groundwork for the establishment of Bedford College eighteen months later. Just as women's involvement in the abolitionist movement and participation in charitable organizations created headway for the women's movements that would come later in the century, so too did Queen's help Bedford test the public's reaction to women in higher education. As examined in the next chapter, while there is no documentation that confirms or denies Elisabeth Reid's awareness of Maurice's efforts, his College's successful opening is mentioned in Bedford's prospectus. It is clear from this document that Reid saw the acceptance of Queen's as an indication society was ready for women in higher education, thus clearing the path for her own institution. The progression of Queen's and Bedford College also mirror the abolitionist and the women's higher education movements in another way. Just as the anti-slavery

\footnotetext{
${ }^{66}$ Ibid, 4-7.

${ }^{67}$ Kaye, 9-14.
} 
movement was considered a safe method for women to become involved in the public sphere, Queen's College can be viewed as a safe entrance for women into the world of higher education while Bedford was seen as an unorthodox and somewhat subversive institution, no matter Reid's intentions. Despite Maurice's dubious connections to the Chartist movement, discussed below, Queen's was an Anglican institution supported by the Church of England and the monarchy, the ultimate goal of which was to train women for a socially acceptable occupation.

The Quarterly Review defined the governess “as being [one] who is our equal in birth, manner, and education, but our inferior in worldly wealth." ${ }^{\text {, }}$ The governess held a special role in Victorian society, one that defied most social norms of the time. By definition, any woman who was obligated to work, to move beyond their natural occupations as wives and mothers, had no social status. There was no other socially acceptable profession for the upper and middle-class woman outside of marriage. Elaine Kaye, author of A History of Queen's College, London 1848-1972, remarks on the dichotomy of Victorian expectations of gender, especially concerning work and marriage. She states, "Victorian propriety ignored many things. One of them was the surplus of women over men; another was the comparatively high proportion of men who did not marry." 69 This meant there were often large numbers of unmarried women, either widowed or single, who without access to private funds were left to the only socially acceptable occupation available, that of governess. However, the education of many of these women was minimal; as governesses, they were expected

\footnotetext{
${ }^{68}$ John Gibson Lockhart, "Editors Note," Quarterly Review, vol. 84, (Dec. 1848), vi.

${ }^{69}$ Kaye, 13-14.
} 
to have and impart knowledge far beyond their reach. Moreover, as it was considered a women's moral duty to nurture and educate children, most families did not deem payment a requirement. In fact, there were frequent advertisements for governesses in The Times, which called for extensive qualifications but offered no salary. ${ }^{70}$ Considering the existing level of education for girls and women at this time, it is not surprising the need was felt to supplement the education and knowledge of governesses. Queen's College of London was primarily established to fill this void. The College opened in 1848, which is often referred to as the Spring of Nations, or the Year of Revolutions. In Europe, demonstrations were occurring continually, revolving around the ideas of nationalism, liberalism, socialism and constitutionalism and upsetting the traditional aristocratic governments. ${ }^{71}$ The wave of movements and revolutions began in France, starting with the French Revolution of 1848, before spreading outwards to the rest of Europe, including Germany, Austria, Prussia and Italy. While these revolutions obtained some measure of success, either in the form of overthrowing monarchies or in the creation of new constitutions, such accomplishments were short lived, as new monarchies were established and constitutions failed to garner widespread support. Still, as Charles Breunig notes, these revolutions were created from both hope for the future as well as despair of present, and that "behind them was a whole wide range of ideals and aspirations for a better world." ${ }^{, 72}$ Perhaps the most significant outcome of the events of 1848 , especially

\footnotetext{
${ }^{70}$ Ibid, 14.

${ }^{71}$ Grylls, 40.

72 Charles Breunig, The Age of Revolution and Reaction, 1789-1850, (New York: Newton, 1970), 253254. For more on the Revolutions of 1848 and the impact they had on Europe, Cf. Breunig; Paul W.
} 
pertaining to the upcoming establishment of Bedford College, was the economic and political gains achieved by the middle class. The involvement of this newly created class particularly held true in England as a result of the transforming power of the Industrial Revolution. Men and women of the middle class continued to be on the forefront of change and reform, in either the political or the social arenas. Reid and her fellow founders fit into this role of middle-class champions of progress, though as will be discussed in the next chapter, the foundress certainly did not see herself or her ideas as particularly radical or subversive. ${ }^{73}$ However, while the revolutions of Europe did not have a direct impact on Bedford's establishment, another movement in England would have a significant role in the foundation of Queen's College.

Though the vast majority of the movements and revolutions of this time transpired on the European continent, England also experienced some demonstrations from agitated and unsatisfied citizens, albeit on a smaller scale than those witnessed in France or Germany. The most notable of London's political movements of this period was Chartism, the high point of which occurred at nearly the same moment of the establishment of Queen's College. ${ }^{74}$ Maurice himself was an active member of the Chartist movement, signing petitions, organizing and printing The Politics for the People, a newspaper for the movement and helping to plan demonstrations and

Schroeder, "International Politics, Peace, and War, 1815-1914" in The Nineteenth Century: Europe 1789-1914, ed. T.C.W. Blanning, (Oxford: Oxford University Press, 2000); and Alan Sked, "The Metternich System, 1814-1848" in Europe's Balance of Power, 1814-1848, ed. Alan Sked, (London: Macmillan, 1979).

${ }^{73}$ Tuke, 13.

${ }^{74}$ Chartism was a social and political reform movement of the mid-nineteenth century, which petitioned for, among other things, a vote for every man over the age of twenty-one, disregarding property qualifications for members of Parliament, and equal constituencies. For more about the Chartist Movement, see Malcolm Chase, Chartism: A New History, (New York: Manchester University Press, 2007). 
marches. Kaye points out that Maurice's involvement in Chartism caused two problems for his new college; not only were his activities in the movement distracting him from the opening of Queen's, but such connections also “brought... a taint of suspicion" to the College. ${ }^{75}$ Many of the more orthodox members of the Established Church had developed a deep skepticism of Maurice and wondered about the curriculum of the new college and the sort of education he was imparting upon the impressionable minds of young girls. Most of the suspicion and the unrest surrounding Chartism and its ideals came from the origins of the group: the working class. Chartism was a mass movement of the working class and was usually neither a quiet nor peaceful one. Revolution and revolt among the lower classes was a fear of the middle and upper classes, though often an irrational one. ${ }^{76}$ Parents worried Maurice and the curriculum of his College could influence their children to be more sympathetic to the ideals of Chartism, though there was no indication that Maurice ever attempted to overlap these two parts of his life.

Maurice addressed these concerns in his inaugural lecture given on March 29, about five weeks before the beginning of the college's first term. The lecture, titled Queen's College: Its Objects and Method, is mostly comprised of Maurice's defense of various protestations made against the college. The two most grievous objections, according to the speech, appear to have been the use of the word 'college' in the title, as opposed to 'school', and the choice of academic subjects. The first offense, apparently arose because some dissenters had problems labeling the new

\footnotetext{
${ }^{75}$ Kaye, $42-45$.

${ }^{76}$ Chase, $15-25$.
} 
establishment a college, when it accepted girls as young as twelve. To this, Maurice argued, "the teachers of a school may aim merely to impart information; the teachers of a college must lead their pupils to the apprehension of principles," adding "study is not worth much if it is not busy about the roots of things." ${ }^{, 77}$ The inaugural lecture goes on to defend the subjects taught at the college, which included, "Arithmetic, Mathematics, Natural Philosophy, Languages, English Literature, Pedagogy, Mechanics, Geography, History, Theology, Drawing and Music."78 These last two subjects caused the most tribulations, as they were considered unnecessary to furthering the education of governesses. However, Maurice stated that drawing encouraged "a power of looking below the surface of things for the meaning which they express," while music possessed the ability to awaken "the sense of order and harmony in the heart of things." 79 The founder of Queen's also spoke of trends that would be avoided at the college, namely competition and the following of fashion. He called upon his teachers to be sure to "admonish his pupils, that they are not to make fashion, or public opinion their rule," for if they are attending class "in order to shine or be admired...they will not be sincere in their work, or do it well." $" 80$

In its first year of existence, 276 students were enrolled at Queen's College, the vast majority of whom were non-compounders, meaning they were not taking the full course load. In, fact, only 31 students in the first year were considered compounders. These initial high numbers are not overly surprising when one takes into account that

\footnotetext{
${ }^{77}$ Rev. Frederick Denison Maurice, "Queen's College, London: Its Objects and Methods," in Introductory Lectures, Delivered at Queen's College, (London: John W. Parker, West Strand, 1849), 7.

${ }^{78}$ Ibid, 8-24.

${ }^{79}$ Ibid, 12-13.

${ }^{80}$ Ibid, 26.
} 
the college was supported by Royal patronage, and that one of its earliest supporters was the Honorable Amelia Murray, a maid of honor to Queen Victoria. ${ }^{81}$ The College was administered by a Committee of Education, most of which were members of the staff of King's College, an institution that had been founded in 1827 by supporters of the Church of England in response to the unsectarian University College. While there were no religious tests for admission to King's, professors were required to be members of the Church of England. This orthodox Anglican atmosphere spilled over to Queen's College, where nearly all of the students, professors, administrators and other staff were members of the Church of England. Maurice himself was the Professor of English Literature and Modern History, and most of his colleagues, also clergymen, were professors at King's College at the same time as they were employed at Queen's. ${ }^{82}$ The college was structured around a system of teaching where the Professors gave lectures and assigned papers, which were graded by a system of Greek letters. In the beginning, the classes were divided into Junior and Senior students, and after two terms, it became necessary to open a School for some of the younger students in the basement of the building. The curriculum, decided upon by the Committee of Education, was designed around the skills and knowledge deemed necessary for governesses to pass on to their future charges, which included the subjects discussed above. ${ }^{83}$ In addition to setting the program of study and selecting professors and staff, the Committee also placed restrictions upon admission to the

\footnotetext{
${ }^{81}$ Kaye, 16-17.

${ }^{82}$ Ibid, 30-32.

${ }^{83}$ Grylls, 8-9.
} 
College. At first, it was decided that no girls under the age of fourteen could attend the lectures, but this age was lowered to twelve before the opening of the college. It was also initially determined that the lectures would be confined to those who were either governesses or intended to become governesses. This decision was also changed before the official commencement of the College, and it was decided that any who wanted to attend the lectures would be allowed to. However, those who were not, or did not intend to be governesses were charged a slightly higher tuition than those who were, or had plans to be governesses. The Committee decided on one other important factor before the opening of the College. All students were to be looked after by both a Lady Resident, who presided over the house in which the college was located, and several Lady Visitors, who served as chaperones for the students in all their lectures and were "to communicate between the teachers of the college and the guardian of its pupils. ${ }^{\Perp 84}$ It is imperative to recognize the importance of this Committee and of Queen's College in general. Nothing of this caliber had ever been attempted before, and at this point, there were no other opportunities for women in higher education. Although Queen's College may have been established with a somewhat narrow focus in training Anglican women to become governesses, the founders of this College were creating a place that allowed women some degree of access to higher education, even if it was limited.

Bedford College was established a mere eighteen months after the opening of Queen's College and looked to the latter for several models and techniques of

\footnotetext{
${ }^{84}$ Kaye 37-39; Maurice, 8.
} 
education. As examined in this chapter, as more and more women began to push gently against the rigid social boundaries of society, it gradually became less shocking and less radical for women to venture outside the fortress of the home, as long as they were involved in a "safe and respectable" movement or charity. These women served as the forerunners for the more drastic activists, not feminists, who would come later in the century. Before that though, Elisabeth Reid would establish Bedford College so that she might help women become better wives and mothers through the means of education. The success of her institution was built upon the burgeoning presence of women in the public sphere and the introduction of women into some form of higher education by Queen's. Still, when Bedford was established in 1849, the notion of women attending a College was a relatively new concept, and a slightly revolutionary and controversial one at that. 
Chapter Two: Mrs. Reid's College:

The Beginning of the Ladies' College at Bedford Square, 1849-1869

She had founded; they must build.

Here might they learn whatever men were taught:

Let them not fear: some said their heads were less:

Some men's were small; not they the least of men;

For often fineness compensated size.

-The Princess, Act I

In 1849, inspired by the apparent success of recently opened Queen's College and guided by the principles of her faith, Elisabeth Jesser Reid fulfilled her dream and established the Ladies' College at Bedford Square. In the years prior to its opening, Reid cultivated a circle of intellectual friends and acquaintances, hosted informal lectures at her home with learned scholars and close friends, and began to query her contacts about the possibility of founding "a College for Women or something like it." 85 The exact motivations behind Reid's desire remain unclear, due mostly to the lack of surviving sources, though many of her reasons can be gleaned from a thorough analysis of what is known of her life, including her childhood, her faith and the words of her friends. This chapter will focus on this analysis of Reid's life, as well as the foundation of Bedford College and the simultaneous creation of the women's higher education movement.

Throughout the process of establishing Bedford College, Reid maintained that her ideas were neither subversive nor particularly radical. ${ }^{86}$ She was not interested in providing education to women purely for education's sake, nor was she attempting to

\footnotetext{
${ }^{85}$ Elisabeth Jesser Reid to Jane Martineau and Elizabeth Ann Bostock, April, 1860, in Tuke, 317.

${ }^{86}$ Tuke, $1-5$.
} 
challenge the male dominated educational system directly. Instead, Reid's goal for her new enterprise was to educate women so that they might become better wives and mothers. While some of her friends were encouraging of her new endeavor, many were cautious, questioning if such an establishment would be a sound decision, especially so close to the opening of Queen's College. Reid would not be dissuaded, however, and threw herself wholly into the project, contributing her own resources to fund the College and calling on her many contacts to help her shape and mold the new institution.

For all her enthusiasm, it is doubtful Reid realized how difficult founding and successfully maintaining her College would be. The summer before the first term was filled with Committee meetings and debates over every detail, including curriculum, fees, location, chaperones, and who would run the College. This last detail would prove to be one of Bedford's more long-standing conflicts. Reid envisioned herself and the women of the Ladies' Committee having a controlling voice in the administration of the College, never mind that few of the women had ever participated in such work before. The Professors and other male members of the College's staff certainly had objections on this point, declaring it inappropriate and unwise to allow these untried women to have total control in Bedford's administration. ${ }^{87}$ Even with these quarrels and difficulties, Reid was still optimistic about her new venture, and was deeply confused and disappointed when only sixty-eight students enrolled for lectures in the first term of the College. During the first two decades the attendance

\footnotetext{
${ }^{87}$ Tuke, 37-45; Crook, 14-18.
} 
rates and income of the College fluctuated wildly, at times nearly bringing closure and bankruptcy, and at others appearing to be headed for profit and continued success.

The establishment of the Ladies' College at Bedford Square signaled the beginning of the women's higher education movement, which gained momentum from the social ferment generated by the women who were entering the public sphere by safe and respectable methods. Unlike those that had come before it, this movement did not have widespread public support or even a central organizing effort. In the beginning, nearly all of the women involved in the movement were connected to either Queen's or Bedford, though their numbers increased as more women were encouraged by the actions of those campaigning for access to higher education. ${ }^{88}$ The women educated at Bedford would become the driving force behind the women's higher education movement, the momentum of which would help ensure the successful establishments of the other women's colleges to come. The success of Bedford was not easily obtained, however, and for many years, the College existed solely on the pure determination of its foundress, whose motivations can be understood through an examination of her life as well as her belief in Unitarianism.

Very little is known about the early life of Elisabeth Reid. She kept no known journal or dairy, and few of her own letters have survived. The small amount of information available about her life comes from the letters and journal entries of her friends, colleagues and close confidants. She was born as Elisabeth Sturch in 1789 to William Sturch, the son of a Baptist Minister. Sturch moved to London from the Isle

${ }^{88}$ Tuke, 50-55. 
of Wight at the age of twenty, where he became an ironmonger, and an active member in the Unitarian movement. Sturch was a highly intellectual man who surrounded himself with other intellectuals with high ideals and aspirations ${ }^{89} \mathrm{~A}$ few years after his move to London, Sturch married and had two children, Mary and Elisabeth Jesser. The daughters were raised in an environment of intellectualism, taught mathematics, reading and writing well above the level of most girls of this period, as well as Latin and Greek. The education given to Mary and Elisabeth was a byproduct of the family's Unitarian faith and it is important to understand the underlying values of Reid's religion, as both it and her unorthodox academic upbringing were key components in her motivations in building a college for women.

Unitarians, so named for their belief that God is a single unit rather than a fusion of three, were a division of Christianity that tended to support liberal spiritual beliefs. Although they lacked most of the religious zeal prevalent among other more orthodox religions of the late eighteenth and early nineteenth centuries, they still maintained a strong commitment towards causes aimed at improving the lower and working classes. The most prominent of these causes were abolitionism, discussed in the last chapter, and education. Unitarians' unique philosophy gave them a different outlook on education than most religions. They believed the coming of a "millenary dawn of peace, brotherhood, and justice" could only be obtained through the

\footnotetext{
${ }^{89}$ Sturch was a "highly respectable and wealthy man" and an avid theological scholar, and was involved in several progressive and philanthropic movements. He regularly published articles on numerous theological subjects and questions in the Monthly Repository and published his own work in 1799 entitled Apeleutherus; or An Effort to attain Intellectual Freedom. Tuke, 3-5.
} 
unrepressed pursuit of knowledge and truth. ${ }^{90}$ Unitarians also had a very different conception of womanhood than was generally prevalent. They rejected the notions of original sin and the fundamental depravity of man, the blame for which were placed upon women, and took a more positive outlook on humanity as a whole. ${ }^{91}$ The combination of these two ideologies gave this unorthodox branch of Christianity a distinct educational philosophy, which called for the spread of both rational religion and a greater access to education for both sexes. For Unitarians, it was important that both boys and girls be educated in rational religion and society; that this knowledge be obtained not from a cramming of facts, but from an education by example through a good home life, and useful and rational studies. It was within this setting that Elisabeth Reid was raised, and it was this she desired to pass onto her students so that they could create better homes for their own family.

Unitarian educators taught women as well as men, reserving neither citizenship nor the understanding of a future built upon a deeper understanding of scientific principles to men only. While Unitarians supported and established institutions of learning for boys and girls, the same could not be said for the education of adult women, as the Unitarians newly established literary and scientific societies were only open to men. Facing this drought of quality institutions for women, many were taught at home within their close family circle or, if they were only just past the age of schooling, were sent to visit relatives or friends who might be able to advance their

\footnotetext{
${ }^{90}$ Ruth Watts, Gender, Power, and the Unitarians in England, 1760-1860, (London: Longman, 1998), 33.

${ }^{91}$ Ibid, 77-78.
} 
education. ${ }^{92}$ By the beginning of the nineteenth century, an active acceptance of women's intellectual capacity had become fully entrenched in the minds of those within the Unitarian network. ${ }^{93}$ The support of this network, both financially and otherwise, would be vital to the establishment of Bedford College, though such an unorthodox tie would be problematic for its beginning years.

Just as Chartism brought a taint of suspicion to F.D. Maurice and Queen's College, so too did Unitarianism cause many to distrust Reid and her new institution, no matter how pure her intentions might have been. Though there is no documentation that explicitly outlines her reasons behind opening a college, it is clear the principles of Reid's faith guided her motivations. Under her direction, Bedford would accept girls of every religion and age, regardless of their financial situation.

Another insight to her reasons can be found from an examination of her (brief) life as a married woman, as well as a discussion of the friendships she forged later in life. In 1821, at the age of thirty-two, Elisabeth Jesser Sturch married a well-renowned physician name John Reid. According to Tuke, Dr. Reid was a man of weak will and nervous temperament, who fell into a state of despondency and listlessness following the death of his first wife in $1816 .{ }^{94}$ She goes on to speculate as to the nature of the marriage between Dr. and Mrs. Reid, claiming,

It is easy to understand that the lonely, neurotic widower appealed to the ready pity of Elisabeth Sturch and that, moved by the benevolence which distinguished her and the impulsiveness which was no less one

\footnotetext{
${ }^{92}$ Ibid, 50-52, 67.

${ }^{93}$ Ibid, $95-96$.

${ }^{94}$ Tuke 3-5.
} 
of her characteristics, she hoped to bring him happiness by marrying him. $^{95}$

Unfortunately, or perhaps fortunately for the new Mrs. Reid, the marriage was short lived, as the doctor passed away in August of 1822, only thirteen months after the couple exchanged vows. ${ }^{96}$ Many years later, Henry Crabb Robinson, attorney and close friend of Mrs. Reid, remarked in his diary that the widow rarely spoke of her husband and speculated that, "He is a man she would not have married now."97 Although Dr. Reid was only a part of his wife's life for a short period, their marriage would have a significant impact on the founding of Bedford College. His death made Reid a wealthy widow, which allowed her to supply the funds necessary to establish her future college.

Following his death and the death of her parents in later years, Elisabeth Reid was free to pursue her personal interests and philanthropic causes, including the antislavery movement and women's education. She made a particular point of befriending several leading abolitionists on both sides of the Atlantic, often hosting meetings and lectures in her own home. It was during this time that Reid met many of the women, and a few of the men, who would become instrumental in the foundation of her college in years to come, including, Elizabeth Ann Bostock, Jane Martineau and Harriet Martineau. ${ }^{98}$

\footnotetext{
${ }^{95}$ Ibid, 4-7.

${ }^{96}$ Ibid, 7.

${ }^{97}$ Henry Crabb Robinson, "Sept. 4, 1849," in The Diary of Henry Crabb Robinson: An Abridgement, ed. Derek Hudson, (London: Oxford University Press, 1967), 159.

${ }^{98}$ Harriet Martineau was not a relation of Jane Martineau. Often cited as the first woman sociologist, Martineau was an intellectual who wrote more than fifty books and strongly believed that an analysis of society was necessary in order to have a complete understanding of women's lives. Tuke, 8-9.
} 
Reid and Harriet Martineau worked on several charity projects together, including a system of improving the local housing conditions of the tenants of Ambleside, where Martineau settled down in the last years of her life. Other than their mutual desire to promote philanthropic enterprises, two constant topics in the correspondence between the two was Martineau's failing health and their continual disagreement on religion. ${ }^{99}$ While Tuke paints a clear picture of Reid's admiration and appreciation of her friend, biographers of Martineau have remarked that the sociologist viewed Reid as "remarkably absent-minded, [lacking] quickness and dexterity, [who] often said stupid things and...[was] amazingly awkward."100 Martineau's opinions were shared by many of Reid's friends and contemporaries alike, though no others were quite so blunt. Still, Reid and Martineau remained friends, each seeking council from the other, especially when Reid began the slow process of founding the Ladies' College of Bedford Square. Martineau would advise her on issues concerning the new center of learning, including potential professors, lecture topics, prospective supporters and patrons, methods of raising funds, and manners of attracting new students. However, Reid's naiveté and her tendency to speak, or write, without thinking did little to endear her to potential sponsors and fellow founders, often making the business of building a new college difficult.

In 1860 , Reid, in poor health and having decided to retire from running the college full time, drafted a letter to Jane Martineau and Elisabeth Bostock remarking

\footnotetext{
${ }^{99}$ Ibid, 9.

${ }^{100}$ R.K. Webb, Harriet Martineau: A Radical Victorian, (New York: Columbia University Press, 1960), 17.
} 
"most of those who know me are aware that a College for Women or something like it, has been my dream from childhood. I have made several attempts but failed for want of cooperation." ${ }^{\prime 101}$ Despite this claim, there is no evidence of Reid ever attempting to found a school or college such as Bedford before 1849. Yet, there is evidence of Reid taking slow and measured steps toward the eventual opening of her college. Beyond hosting lectures in her home, she utilized her numerous contacts within the intellectual community, inviting persons who were experts in their fields to come and speak to her and her wide circle of friends. The topics presented varied, ranging from current political events and ancient history to botany and mathematics. ${ }^{102}$ These lectures were an important step in the establishment of Bedford College. Not only did they serve to further Reid's contacts in the intellectual community, they were also evidence of interest among her peers in a higher form of education. These talks were designed for the benefit of Reid and her many female friends to help expand their limited knowledge. While Reid was hosting these lectures and considering the notion of expanding into a full college, F.D. Maurice and his supporters opened the doors to their own institution.

It is unclear from what little of Reid's correspondence survives whether or not she was aware of the dealings of the Governess Benevolence Institution and the establishment of Queen's College. In July of 1849, three months before Bedford opened its doors, Harriet Martineau wrote to Reid questioning the need for a second college. "Is it the teaching that is different, or the plans? Or is it for the sake of a

\footnotetext{
${ }^{101}$ Elisabeth Jesser Reid to Jane Martineau and Elisabeth Ann Bostock, 1860, in Tuke, 317.

${ }^{102}$ Ibid, 28.
} 
neighborhood? Only it is not very far from the other." ${ }^{103}$ The reply to this letter is lost, but the answers to most of Martineau's questions are found in the first "Prospectus of the Ladies' College in Bedford Square.” The document begins by stating,

It is now a year since Queen's College, in Harley Street, was founded for the Education of Young Ladies. The success of this Institution proves that its founders rightly estimated the demand for a better and more extended system of female education than any which is previously been accessible. ${ }^{104}$

While it is not expressly stated in this prospectus, it can easily be deduced that Reid and the other founders of Bedford College waited to see how well the general population received Queen's College before they set about establishing and opening their own Ladies' College.

According to J. Mordaunt Crook, author of Bedford College, University of London: Memories of 150 Years, there exists some controversy now as to whether or not Bedford can legitimately make the claim to be the first college for women in Britain. While Queen's did begin educating girls and women more than a year before Bedford, its structure and curriculum was more akin to a training school than a college. In the first few months following Queen's establishment, all enrolled students were required to take courses that would train them to become governesses for upperand middle-class families. This rule was eventually discarded, though girls who did not indicate this career as their reason for entering the school were charged a higher fee. ${ }^{105}$ Reid, on the other hand, established Bedford for "the elevation of the moral and

\footnotetext{
103 Ibid, 23.

104 “Prospectus for a Ladies' College in Bedford Square," in Tuke, 319.

105 Kaye, 37-39.
} 
intellectual character of women, as a means to an improved state of society."106 Although Tuke maintains this does not mean Reid was advocating for learning for learning's sake, it is clear the foundress meant for women to be able to use their education for a broader purpose than only to be governesses. The curriculum of Queen's College only offered courses that would provide their students with the skills necessary to tutor their future charges, such as Arithmetic, English Grammar, History and Method in Teaching, and did not offer any of the more advanced courses of Mathematics, English Literature, Ancient and Modern History, and Scientific Geography that Bedford's instructors provided. ${ }^{107}$ Therefore, the debate over Bedford's claim as the first college for women can be settled with an examination of the goals of each institution, as well as their offered courses. While the establishment of Queen's College was an advancement for women's schooling, the education provided by Queen's should not be confused with that given by Bedford College and the achievements made by Reid and her fellow founders.

The months leading up to the opening of Bedford College were filled with the establishment of several management committees (composed almost entirely of friends and acquaintances of Reid), the soliciting of funds and support from outside donors, the meeting of the committees to decide upon subjects, fees, professors and location of the college and the drafting of the College's prospectus. None of these tasks were particularly easy, and they were only made all the more difficult by the lack

\footnotetext{
${ }^{106}$ Elisabeth Jesser Reid to Henry Crabb Robinson, March 1858, in Robinson, Diary and Correspondence, 374.

${ }^{107}$ Kaye, 38; "Prospectus for a Ladies' College in Bedford Square," in Tuke, 319.
} 
of precedents associated with the establishment of an institute of higher education for women. Bedford also faced a number of challenges due to its somewhat dubious connections. Unlike Queen's College, which had royal and upper class support and was associated with the Church of England, Bedford was closely linked with the highly unorthodox University College. In fact, many of Bedford's original professors were also employed at this college. However, one of the greater disadvantages facing Bedford was the strong presence of Unitarians in the College, including Reid and many of the council members and supporters. While the college itself was designed to be non-sectarian in nature, and to include members outside the Unitarian faith, it was still considered a suspect place to the people of London, especially when questions of religious beliefs were frequently on the forefront of people's minds. ${ }^{108}$ These suspicions were not at all belied by those to whom Reid reached out for help, as the vast majority of them were also Unitarian and unorthodox. She was either unaware of the shadow cast upon the College by this connection, or more likely uncaring, as a letter written by her to Sophia Elizabeth De Morgan exclaims, "Is it not perverse that all the best people will be [sic] Unitarians."109 Though such blind enthusiasm for her cause at times helped to win over potential donors, it also was the source of contention between Reid and the various members of the councils of Bedford. At this point in the

${ }^{108}$ For more on the volatile religious atmosphere of England and London in the late 1840s, see David Nash, Blasphemy in Christian World: A History, (Oxford: Oxford University Press, 2007) and Edward Royle, Victorian Infidels: The Origins of British Secularist Movement, 1791-1866, (Manchester: University of Manchester Press, 1974).

${ }^{109}$ Elisabeth Jesser Reid to Sophia Elizabeth De Morgan, May 22, 1849. RHUL Archives RF 103/3/1. De Morgan was a member of the original Ladies' Committee and one of the first Lady Visitors of Bedford. She was married to the famed British mathematician, Augustus De Morgan, who formulated De Morgan's laws and introduced the term 'mathematical induction.' He was a professor at London University College and was the first Professor of Mathematics at Bedford College. Crook, 18-20; Tuke, 320 . 
College's history though, Reid was far more focused on the practical aspects of opening a new institution, including funding, students, professors and a location for the College.

There were several topics on which Reid wrote to friends and casual acquaintances alike looking for advice especially concerning the problematic issues of securing funding and a location for the College. Reid herself had pledged $£ 1,500$ to the College as a loan to "prime the pump," so confident in the success of her venture that she expected the money to be repaid within three years. When friends expressed doubt as to whether such a large investment was sound, she replied:

I am perfectly happy to take the risk as you term it, and feel far too confident of its success to admit of any generosity in the affair. If they pay Interest, I shall probably spend it upon Pupils so they can judge which is best for the institution. When they repay me, I should wish to employ the sum in the same way elsewhere. ${ }^{110}$

As noted earlier, few of the letters written by Reid have survived to the present, although there are a number of letters received by her have been preserved. From these documents, the difficulty of her efforts and the strength of the resistance against her are clearly evident.

In a letter Reid received in 1850, a Mrs. R.W. Markay, who appears to have been a friend of Reid's older sister Mary Sturch, refused to donate to the College due to the content of the education being given to the students. "I greatly admire and respect your enthusiasm," she writes, "but the means of improvement may be sought in a variety of directions - and while unable to see my way clearly to the end in the

\footnotetext{
${ }^{110}$ Crook, 15; Elisabeth Jesser Reid to Sophia Elizabeth De Morgan, Feb. 1849. RHUL Archives, RF $103 / 3 / 4$.
} 
direction which you propose, I devote my existence and all the little energy I possess to seeking it in another." ${ }^{111}$ Her letter goes on to mention the weakness of Reid's church and failing to see how supporting such a venture would be beneficial. "It is a mistake to suppose that the giving of money will of necessity render people wiser and better... and I have little faith in the efficacy of English establishments and English teachers to effect the desired object in the already satisfactory manner."112 Though Reid's reply to Markay, if there was one, has not survived, it is not very difficult to speculate on her immense disappointment and frustration at the lack of vision displayed in this correspondence. It is also not difficult to envision that Reid received many other letters such as this, refusing monetary assistance or suggestions of pupils and teachers on the grounds of an ideological and theological difference. ${ }^{113}$

Fortunately, not all of Reid's correspondence was so disheartening. She received several letters of encouragement from Henry Crabb Robinson, as well as a donation of $£ 50$, and several recommendations for teachers and other prospective donors. While Robinson was supportive of "Mrs. Reid's College," as he often referred to Bedford in letters to other friends, he cautioned her to not "ascribe too much to the imagined disregard of female education by men," lest she inadvertently deflect potential supporters. ${ }^{114}$ Robinson himself often bemoaned the narrow-mindedness and lack of foresight displayed by some people, especially those deeply entrenched in the Christian faith. In a letter written to Reid a few years after the opening of the College,

${ }^{111}$ R.W. Markay to Elisabeth Jesser Reid, 1850. RHUL Archives, RF 103/8/20.

${ }^{112}$ Ibid.

${ }^{113}$ Markay closed her letter by asking, "Why should I step forward to nominate teachers in whose lessons I cannot acquiesce?" Ibid.

${ }^{114}$ Henry Crabb Robinson to Elisabeth Jesser Reid, Nov. 6, 1856. RHUL Archives RF 103/4/19. 
he stated he was certain religion would be the eventual downfall of education for men and women. "It is a deplorable fact that the Professors of the only Christian faith which offers hopes to the whole community of men and does not threaten much more than it promises, are poor in number in means or in earnest solitude for the spread of that faith." 115 Unlike Reid, Robinson was careful to share such opinions only with those who were like-minded and presented a neutral façade towards those with whom he disagreed. ${ }^{116}$ According to the few accounts that exist describing Elisabeth Reid, she was awkward and often times thoughtless in her speech, which made it difficult for potential donors outside her circle of friends to look past her brash exterior. As Reid grew older, and her health grew worse, the business of soliciting donations and finding benefactors were left to the far more politic members of College. ${ }^{117}$ This change of leadership, which is discussed in detail later in this chapter, would result in a distinct shift in Bedford's management style, to one that was designed more towards the survival and the success of the College. This shift would eventually bring more students and funds into Bedford, as well as help to secure more permanent staff members and better lodgings for the College.

Beyond the undertaking of seeking out Professors and funds, Reid was also in search of a building to house her new college. This presented several difficulties, the most pressing of which were the requirements for its physical location. The building needed to be in a good neighborhood, so that neither parents nor students would fear

\footnotetext{
${ }^{115}$ Henry Crabb Robinson to Elisabeth Jesser Reid, Jan. 1, 1852. RHUL Archives RF 103/4/11.

${ }^{116}$ Hudson, 5-6.

${ }^{117}$ Tuke 1-20; Webb, 17.
} 
for their safety, yet not so good of a neighborhood that they might not be able to afford the rent. It also needed to be located fairly close to the University College of London, where many of Bedford's professors were also employed, but far enough away from Queen's College on Harley Street to eliminate the possibility of overlap in prospective students. A letter written by Reid in February of 1849, eight months before opening term, to De Morgan conveys her frustration at being unable to locate such a building, having found houses large enough in Gt. Ormond St., but not being satisfied with the "shabby genteel" nature of the surrounding neighborhood. She also offered a solution for the professors who complained such a location might be too far away from their other posting: "Can't you persuade the Professors the exercise is good for them? a [sic] good run from one College to another?"118 Eventually a house at No. 47 Bedford Square was chosen, the location of which would be lent to the name of college, known now as the Ladies' College at Bedford Square. Although it was relatively close to Harley St. and Queen's College, it was decided upon "from its being in the centre of a populous and wealthy neighborhood, where such advantages as this College affords will be particularly valued." ${ }^{119}$ With a location secured, professors and a handful of students pledged and a small pool of funds collected, Reid and the other founders went about the task of forming, shaping and molding their resources into what would soon become the Ladies' College at Bedford Square.

In the summer of 1849 a General Committee was formed, which would consider and approve all matters relating to the preliminary characteristics of the

\footnotetext{
${ }^{118}$ Elisabeth Jesser Reid to Sophia Elizabeth De Morgan, Feb. 1849. RHUL Archives RF 103/3/1.

119 "Prospectus for a Ladies' College in Bedford Square" in Tuke, 319.
} 
College. Several other committees were also formed at this time, including an Executive Committee, a Sub-Committee and a Ladies' Committee. This last committee was part of Reid's vision for the management of her new foundation, a notion almost completely unheard of in this time. She anticipated this Ladies' Committee would have a controlling vote and significant voice in the planning of the College, with advice and help from the Professors, the title given to all who taught or gave lectures at the College. This idea ultimately proved to be severely impractical, as many of the women had never served on a committee of any sort before, and had no notion of how to perform managerial tasks. They had little to no knowledge of committee discipline and many were slow to learn the skills necessary to serve competently. This was particularly noticeable, and subsequently troublesome for the Professors "with whom the women were to work on the General Committee [and] it was also apparent in their own, initially far more important Ladies' Committee."120 Though Reid desired them to take a more commanding role in the College, the women of these committees simply lacked the expertise and the status necessary to lead the governing body of Bedford. In addition, the men of these newly formed committees were unprepared and unwilling to let themselves be governed by women. The considerable lack of leadership and committee skills among the women would remain problematic throughout the planning of the college and through the beginning years of Bedford.

\footnotetext{
${ }^{120}$ Bentley, 5.
} 
By the beginning of September, the Executive Committee had hired nearly all the Professors for the coming school year, agreed upon a prospectus, outlined what subjects were to be taught, formed a group of Lady Visitors, defined their duties and decided upon a course of action concerning religion and Bible study. According to the Prospectus, the first subjects to be taught at Bedford included, Ancient History, Modern History, Biblical Teaching, English Literature, Moral Philosophy, Mathematics, Natural Science, Astronomy, Scientific Geography, Latin, German, French, Italian, Elocution, Vocal Music, Harmony and Drawing. ${ }^{121}$ The name and credentials of each professor responsible for teaching these topics is also listed, and here it is interesting to note the overlay in positions. For example, the Reverend A.J. Scott, a professor of English Literature at London University College, taught Moral Philosophy in addition to English Literature at Bedford; the Reverend J. Booth of Trinity College oversaw both Astronomy and Scientific Geography; a Professor Hullah of Queen's College taught the young girls of the College Vocal Music, Elocution, and Harmony, in addition to teaching the drawing class. ${ }^{122}$ In 1856 , Bostock wrote to Reid commenting on the College's newly vacant Mathematical professorial position, and suggested that whomever they hired should also be able to take over the Natural Philosophy position as well. ${ }^{123}$ The prospectus also listed the names of the women who served on the first Committee of Ladies, who were responsible for overseeing "the conduct and convenience of the Pupils" and the names

\footnotetext{
121 “Prospectus for a Ladies' College in Bedford Square" in Tuke, 319-320.

122 Ibid, 320.

${ }^{123}$ Elizabeth Ann Bostock to Elisabeth Jesser Reid, 1856. RHUL Archives, BC RF 103/1/43.
} 
of the members of the General Committee, and laid out the opening and closing dates of each of the ten to twelve week terms. ${ }^{124}$ Beyond outlining the goals and guidelines of the new College, Bedford's prospectus also served to assuage some fears prospective women and parents of young girls might have had. It was no coincidence that the women of the Ladies' Committees were mentioned before the male members of the General Committee or that Biblical Studies was the first to be listed among the available subjects, as both religion and a strong female presence were especially difficult matters the Committees had to deal with before Bedford opened. Although this document was a common occurrence among other College and Universities, Bedford's prospectus was decidedly remarkable, as one had never before been written with quite this content. While Maurice and the other founds of Queen's College had also written a prospectus, many of its provisions were markedly different from those of Bedford's, specifically the sections on religion.

Religion was a particularly tricky issue at Bedford College. While Queen's College had been designed as an Anglican institution, Reid and her supporters had always intended for their College to be non-sectarian in nature. Yet such classification carried the risk of the college being deemed "godless" as University College had been. Therefore as a precaution, the General Committee decided to include Bible Studies as a central subject in the College's curriculum, though it was to be taught from a strictly non-sectarian point of view. ${ }^{125}$ In addition to this course, the General Committee unanimously agreed, "that the Biblical Department should be placed under the control

\footnotetext{
124 “Prospectus for a Ladies' College in Bedford Square” in Tuke, 319-321.

${ }^{125}$ Crook, 15.
} 
and in charge of all the clergymen who shall for the time be connected with the college." 126 This allowed the College to maintain a certain amount of creditability in regards to religion, though Bedford's non-sectarian approach, acceptance of students outside the Anglican faith and deep Unitarian roots would remain problematic for many years.

In 1855, Elizabeth Bostock wrote to Reid to express her concerns that the lectures and syllabi of a Professor Taylor might appear "too Unitarian" to persons outside the College. "Those who hear Mr. Taylor will not object to a word he says," she writes, "... but this [syllabus] will go into the hands of numbers of persons who will not hear the lecture, and it will strengthen the notion that Unitarianism is being taught here." Bostock further asserts that she does not make this request out of cowardice, but rather out of conscience:

It is easy for you to be liberal, being free \& independent in all the world, but I confess I feel some qualms of conscience of being liberal at the expense of others; namely the hardworking professors \& the poor helpless girls, all these will suffer by the College being thrown back as it assuredly will for some time. ${ }^{127}$

Religion, along with the unorthodox views of Reid and the other founders of Bedford, continued to be a difficult subject for the College, creating controversy, and sometimes causing the withdrawal of students and denial of monetary support. Many of these problems occurred during the early foundational years of the college and a number of these difficulties became more pronounced with the establishment of the women's colleges at Cambridge and Oxford.

\footnotetext{
126 Tuke, 33.

${ }^{127}$ Elizabeth Ann Bostock to Elisabeth Jesser Reid, 1855. RHUL Archives, BC RF 103/1/17.
} 
Other than religion, another task the various Committees of Bedford needed to address before the official opening of the college was how to protect the virtue of their pupils, particularly the younger girls who might enroll. While the virtues of the older matrons were not in danger of being compromised, allowing girls as young as twelve to sit unsupervised in a class with a male professor was unheard of. To solve this quandary, the Committees looked to Queen's College. When establishing his college, F.D. Maurice made provisions for a Lady Resident, who was to preside over the house in which the pupils resided and for a group of Lady Visitors, who were to chaperone the girls to the professors' lectures and provide a communication link between the guardians of the pupils and the professors and the teachers of the College. ${ }^{128}$ Bedford used this same model for their students, drawing upon the women of the Ladies' Committee and Reid herself to be the first of the Lady Visitors. However, Bedford seems to have taken the duties of the Lady Visitors a step further than Queen's, giving these women slightly more authority than that of a chaperone or messenger.

At Bedford, the Lady Visitors were also responsible for enforcing the rules of the college and the pupil's residence, as it was deemed improper for the male professors to decide punishment for the young pupils. ${ }^{129}$ Still, the most important and most "laborous" duty of the Lady Visitors was the supervision of the students. This task included constant chaperonage during lecture hours, meaning they were required to attend lectures for several hours a week, punctually and without fail, often times on

\footnotetext{
${ }^{128}$ Grylls, 8-10.

${ }^{129}$ Tuke, 48-49.
} 
topics about which they may have had little to no interest. ${ }^{130}$ The duties of these

Visitors were defined at a meeting of the Executive Committee:

Every Visitor will endeavor to uphold decorum and silence in the Institution, and maintain in her Class Room attention and punctuality; With a view to the health of the Pupils, the Lady Visitors are requested to direct their attention to the ventilation and general comfort of the rooms. $^{131}$

The new chaperones were also to attempt to befriend their charges, so that the pupils might look to them for advice and assistance. In the beginning, twentyone Lady Visitors were appointed, a number that quickly grew to thirty-nine by the opening of the College. This number was not maintained for long, and neither was the absolute authority of the Visitors. Just as the men of the Executive Committee were unwilling to be led by women, so too were they and the professors reluctant to heed the advice from the Lady Visitors on matters concerning the students. This disagreement over control would be a constant struggle within Bedford's Council, and would not be resolved for several decades.

With most of the major issues facing the college now addressed, including the difficulties of religion and the delicate subject of female propriety, Bedford College was ready to open. Many of the founders at Bedford, and especially Elisabeth Reid, expected their new college to be every bit as successful as Queen's College had been upon its opening, if not more so. Unfortunately, in their opening term only sixty-eight students registered, the majority of whom were older married women who attended

\footnotetext{
${ }^{130}$ Crook, 15-17.

${ }^{131}$ Bentley, 7.
} 
lectures out of general interest. ${ }^{132}$ These initial low numbers were presumably the result of the overall novelty of women in a college setting and the unorthodoxy associated with Bedford. However, it is the ages of the students that reveals more about the early attendees of the College. The relatively high proportion of mature married students is likely leftover from the time of Reid's home lectures, and is further evidence for women of the middle class at this point in the nineteenth century perceiving education as a means of breaking their daily ennui, as opposed to viewing it as a means of bettering themselves or challenging a male dominated system. The low number of younger unmarried students can be attributed to the lack of parents willing to place their daughters in a situation that might label them "unmarriageable," as educated women tended to be viewed. Low enrollment numbers continued to plague Bedford for the next two decades, until leadership was passed on to the women of the Reid Trust, and at which point the notion of women in higher education was not quite as novel as it had been at the College's opening, an assertion which will be discussed later in this chapter.

The state of Bedford's finances was a troublesome point for the College and the Council, so much so that many of its critics doubted it would last more than three years. Around this same time, the women's higher education movement slowly began

\footnotetext{
${ }^{132}$ It is interesting to note, that despite the vast amount of meticulous planning and close attention to detail that was involved in the designing and establishing of the Ladies' College at Bedford Square, the exact opening date of the college was never recorded. We do know Bedford officially began classes with the Michaelmas term in 1849, though there is some debate over whether this took place in September or October, and no document mentions a specific date. Calendar of Bedford College, London, 8 \& 9 York Place: Printed for the Council, (London: Spottiswoode \& Co., 1888), 102-104; Crook, 16-17. (Since the Feast of St Michael (September 29) occurred on Sunday in 1849, it is very likely that the college opened the first week of October. http://www.hf.rim.or.jp/ kaji/cal/cal.cgi?1849, downloaded, 4 June2011.)
} 
to pick up momentum, largely due to the establishment of Bedford and Queen's and to the ferment created by women involved in earlier movements. This movement would have a profound impact on the new College, providing it with both students and funding, although it would be several years before either of these would appear in large enough numbers to allow Bedford strong financial stability.

The women's higher education movement varied greatly from the social movements that had come before. It had little to none of the wide-ranging public support the Abolitionists had received, nor did it have their structured organization. Still, the greatest difference between these movements was the gender of the participants. Nearly all of those active in the higher education movement, from organizers to funders to members, were women. There were no groups of men campaigning for the right of women to have access to higher education. ${ }^{133}$ Indeed, it is even difficult to label this a "movement" at this early stage, as it had few followers or supporters outside of Bedford and Queen's. These two colleges, Bedford especially, were essential in the fight for women's education. Many of the students of Mrs. Reid's College would go on to lead the fight for women to be allowed into the prestigious universities of Cambridge and Oxford, and eventually to earn the right to sit for examinations and be awarded degrees. Bedford College and its unorthodox partner University College would lead the way for degrees for women, a topic that will be discussed in the next chapter.

\footnotetext{
${ }^{133}$ Burstyn, 22-24.
} 
With all of the excitement she felt in the months leading up to that first term at Bedford, to say nothing of all the hard work she devoted to her new venture, Elisabeth Reid must have felt a fair amount of disappointment following the opening of her College. Given the College's continued lack of success, it is doubtful this frustration diminished very much over the course of the next three years. In 1852 , she wrote a letter addressed to the Lady Visitors, stating,

The want of success of our College is very discouraging and would be dreadful indeed could the past be conceived as a fair trial of the scheme. But...we must all see that if had no chance; such succession of misfortunes perhaps never was heard of as befalling an infant institution aiming only at usefulness in a simple and unassuming way. $^{134}$

Reid's downtrodden words, though perhaps a bit melodramatic, are an accurate portrayal of what she termed "a three year "hurricane.",135 Of the original sixty-eight students who first registered at Bedford, forty-two attended only one set of lectures each, the majority of whom were "ladies of mature age." Of the rest, fifteen attended two sets each, eight went to three sets and only three students attended four sets of lectures. Given the haste with which the College had been established, these low numbers are hardly surprising. However, while the second and third terms of the first year saw double the initial number of students, the second and third years of the College brought a sharp decline in the student population, as well as the loss of more than half of the original faculty and staff. ${ }^{136}$ The reasons for these losses can be ascribed to the general lack of funds and support as well as the withdrawal of

\footnotetext{
${ }^{134}$ Elisabeth Jesser Reid to the Lady Visitors, April 30 1852. RHUL Archives, RF 103/2/24.

135 Ibid.

136 Tuke 60-62, Chart V, n.p.
} 
previously promised funds, an overly optimistic view of the level of education held by the new students, and an overall lack of a structured plan of study for the students.

Until 1856, the College operated in a somewhat informal manner. A number of lectures were held at Bedford, but there were no set courses for students to follow, no systematic plan of study. ${ }^{137}$ Students took any classes they found interesting, which is likely the reason the more popular subjects in the first year were Moral Philosophy, English Literature, Ancient History, German and Drawing. ${ }^{138}$ Mathematics was also a popular course in the first two terms of 1849 , although the class sounded more impressive on paper than it was in reality. In truth, none of the women or girls registered in the College had more than basic arithmetic knowledge. This lack of knowledge in pupils caused Mathematics professor Augustus De Morgan to leave Bedford in frustration, which also caused the popularity of the course to take a swift decline. ${ }^{139}$ By the end of the first year, two other prominent professors would leave Bedford, the Rev. C.G. Nicolay of Biblical Studies, and the Rev. J.S. Brewer of Modern History, both of whom left for reasons similar to De Morgan.

While De Morgan's loss was a blow to the prestige of the College, the departure of Nicolay and Brewer posed a far more serious problem. Their withdrawal further emphasized the shadow of unorthodoxy that covered Bedford, as they both

\footnotetext{
${ }^{137}$ Henrietta Busk, Short History of Bedford College (for Women), (London: Baker St., 1899), 9-10.

${ }^{138}$ Moral Philosophy and English Literature, both taught by the Rev. A.J. Scott had seventy-nine and fifty-two students respectively over the course of the first year; German, taught by Professor Heimann had sixty-four students; Ancient History with Professor F.W. Newman had thirty-six students; and Drawing with W. Sterndale Bennett, Esq. saw sixty-two students in the first year. "Distribution of Students in Classes, 1849-1850" in Tuke, 323-324.

${ }^{139}$ In the first two terms of Bedford, thirty-five students were enrolled in Professor De Morgan's course. Following his departure, the Rev. J. Booth who was also teaching Astronomy and Scientific Geography at the time, took over Mathematics. Only eight students took the course in the third term. For more on De Morgan, see note 24. "Distribution of Students in Classes, 1849-1850" in Tuke, 323-324.
} 
carried connections to the far more socially acceptable King's College. The Principle of King's was decidedly opposed to any connection between his College and the new socially questionable Bedford College and refused to allow either Nicolay or Brewer to hold any office in the new College after the first term if they wished to remain employed at King's College. As Bedford paid their professors very little due to their lack of funds, both men were forced to resign. ${ }^{140}$ Beyond the creditability they had brought to the newly established College, the loss of Nicolay and Brewer was especially hard for Reid and the other founders, as both men had been instrumental in its creation. Nicolay in particular had helped to form the religious policies and foundations, campaigning hard with Reid to ensure Bedford held a spirit of tolerance and non-sectarianism. $^{141}$

While these losses were devastating to the curriculum and reputation of Bedford, these two men were not the only professors to leave the fledging institution. The Professor of French, Raymond de Vericour resigned after the first term. Dr. W.B. Carpenter of Natural Science left after the end of the third term for reasons similar to De Morgan. Much like the prominent professor of Mathematics, Carpenter was very well known in his field of physiology and invertebrate zoology. ${ }^{142}$ By the end of

\footnotetext{
${ }^{140}$ Crook, 18.

${ }^{141}$ Calendar, 37, 48.

${ }^{142}$ Carpenter was elected as a Fellow of the Royal Society in 1844 and was appointed as a Fullerian Professor of Physiology at the Royal Institute in 1845 . He wrote nearly a dozen books in his lifetime, the most famous of which was Use and Abuse of Alcoholic Liquors (1861), which was one of the first books ever to promote alcoholism as a disease. After he left Bedford, the Natural Science position was filled by the far less eminent "Mr. Solly," who was able to teach the chemical side of the science, but the official Professorship position of Natural Science was not filled when the College started again in the Fall. Tuke, 302, 65-66.
} 
Bedford's first year, six of the thirteen original professors had resigned their posts, and their positions proved to be incredibly difficult to fill.

Other than the problems of a connection with an unorthodox institution and the frustration of teaching students who were well beneath the level of education they were accustomed to teaching, potential professors of Bedford College also faced the certainty of receiving very little pay. As resident student Meta Brock wrote, "The fees were low. [Bedford] was not intended for the daughters of rich men and I do not think any of us came from very wealthy homes." ${ }^{143}$ According to the prospectus, "Ladies, above the age of twelve... [with] a satisfactory reference" were to be charged:

One Guinea and a Half per Term for every class that meets twice in the week, and a Guinea for every class which meets once: but by paying a composition of Nine Guineas a Term, a pupil may select from any of the Classes to the extent of eighteen Lessons a week. When Classes meet oftener than twice a week, the fee will increase in the same ratio. $^{144}$

These low fees, while allowing many young girls and women who might not be able to afford higher education otherwise, made it difficult to offer any sort of competitive wage to the professors or to the other staff members of the College. For the first forty years, there was no fixed payment for the professors of Bedford, and oftentimes their pay depended on how well funded the College was. At best, professors might receive a fee of $10 s$. or $10 s$. and $6 d$. an hour, which did little to encourage new professors to lecture at Bedford. ${ }^{145}$ According to Tuke, the discontent caused by "the low

\footnotetext{
${ }^{143}$ This comes from an open letter Brock wrote to the College in 1899, thirty-eight years after she first entered in 1861. Meta Brock to Bedford College, London (For Women), 1899. RHUL Archives, PP $60 / 2 / 1 / 1 / 3 / 16$.

144 “Prospectus for a Ladies' College in Bedford Square" in Tuke, 321.

${ }^{145}$ Crook, 17.
} 
remuneration...horrified Mrs. Reid, who imagined all persons who joined in the work would be (and could afford to be) as generous and disinterested as herself."146

This discord between the ideal that Reid and the other founders envisioned versus the reality of operating a College came to be the theme of Bedford's early years. Donors and funds were not accumulating in the numbers the founders, or at least Reid, had been expecting, causing the College to face closure several times in its early history. More problematic was the low level of education possessed by the students, which the professors often found extremely challenging. In addition to these problems, quarrels between the Lady Visitors and the Professors were occurring with increasing frequency and fervor, which made Council matters all the more difficult to resolve.

After the College opened, a constitution was drafted and the administrative bodies that had been instrumental in building the foundation of the institution changed to allow for their new roles as the governing heads of Bedford. The General Committee became the Board of the College, and their powers changed to those of an Appeals Board, intended to answer any questions relating to the new constitution of the College. All executive functions now fell to the newly created "Council of Management," which consisted of nine members, one of the three original trustees, two representatives of the Board ('one lady and one gentleman'), three from the Lady Visitors and three from the Professors. According to this new constitution, the four women on the Council were to possess a final executive authority in "all matters in

\footnotetext{
146 Tuke, 66.
} 
which female propriety or comfort is concerned," the same authority that had been granted to the previous Ladies' Committee. ${ }^{147}$ In addition, both the Professors and the Lady Visitors created separate Advisory Committees to the Council. This form of administration, along with a well-framed constitution was more practical and feasible than a government of two committees. According to Tuke though, the women were unhappy as they "expected to have the management of the College more definitely in their own hands. ... Reid accepted it rather than see a break-down in the proceedings, though as a letter to a friend indicates, with serious regrets." ${ }^{148}$ Although these women expected considerably greater authority, the same issues that had plagued the original Executive Committee still existed. Few of the newly appointed women had any experience in large-scale administrative duties and the male members were disinclined to relinquish authority to inexperienced women. Again, though Reid desired women to have a more commanding role in the management of the College, neither she nor the other women would possess the leverage or the know-how to be in command until after Reid's death in 1866, when financial control was given to the women of the Reid Trust. $^{149}$

Though it would take several years before the conflicts between the governing men and women of Bedford would be resolved, other problems were solved quickly, such as the difficulties of retaining funds and pupils. In 1851, Reid made an entry in the Lady Visitor's log, bemoaning the low student enrollment. "Can anybody explain

${ }^{147}$ Calendar, 33-37.

${ }^{148}$ Tuke does not cite either the source of the women's unhappiness or the letter of Reid. Tuke, 30-31. ${ }^{149}$ The 1869 Incorporation of the College involved a complete renovation of Bedford's administrative system, necessary due to the College's near bankruptcy and closure at the time. The Incorporation will be discussed more thoroughly in the next chapter. Ibid, 35, 53, 100-103. 
the failure of this College? Or tell how it is that, where one might expect several hundreds, the number who seem to look for Education here is somewhere under nineteen?" ${ }^{150}$ In her characteristically exaggerated way, Reid summarized the nadir the college had reached. By the first term of 1851, the College's expenditure was nearly double its income, and the fees from students barely covered the pay for the Professors. ${ }^{151}$ Bedford was on the brink of closure, though the end of the Michaelmas term brought some small amount of hope. Appointments had been made of five candidates for the seven empty professorial jobs, one of whom was Professor Alexander Bain, who was hired to fill the Moral Philosophy and Geography positions. ${ }^{152}$ By the beginning of the second term, student entries were on the rise, as was the amount of income. In an effort to continue this upward movement, Reid retired from the Council and focused her efforts on securing more outside scholarships to allow girls of lesser means to attend the College.

Yet, convincing the Council to accept these funds proved to be nearly as difficult as finding willing donors, preferring to receive donations over accepting scholarships. Some members were worried the competition over funds would be unhealthy for the young girls; others were concerned over the public image of the College, as the acceptance of scholarships might give the impression Bedford was a

\footnotetext{
${ }^{150}$ Elisabeth Jesser Reid entry in Lady Visitor log, Dec. 20, 1851, in Tuke, 76-77. Tuke points out "the number of 19 does not tally with the recorded entry of 84 pupils for the term. Perhaps Mrs. Reid refers to new entries or to pupils taking more than one course of lectures."

${ }^{151}$ Tuke Chart II, n.p., Chart III, n.p.

${ }^{152}$ Alexander Bain was a graduate and former Professor of Moral Philosophy at Aberdeen. He published several philosophical and psychological works, was one of the first Englishmen "to apply Psychology to the results of physiological investigations," and strongly advocated for a reformation in the teaching methods of natural sciences. Ibid, 76-77, 300.
} 
charitable institution. ${ }^{153}$ Though it took several meetings of the Council, by December 1851 the scholarships were accepted with a few conditions. Scholarships were only to be awarded to students already in the College and there were to be no special examinations. Instead, the scholarships were based on the work the students had completed during the year. ${ }^{154}$ Still, Reid faced the difficulties of finding donors like herself who were willing to give substantial sums. She recorded a few smaller donations she had been able to secure in the Lady Visitor's Log, such as the $£ 20$ from the Rev. Edwin Chapman. "Insignificant as this is, it deserves commemoration as being the only instance, as far as I can learn, of a gentleman giving more than Ten Pounds to promote the higher education of women." 155 Securing funds from her fellow founders proved to be far more difficult.

By this time, Reid realized the College was not going to be able to reimburse her original $£ 1,500$ loan, and instead deemed it a gift to Bedford. However, she was infuriated to discover no other Lady Visitor, Professor or founder had made any donation over $£ 10$ and that the College was being funded solely on student fees and her initial loan. Angered, she wrote a letter to the Lady Visitors demanding, "each Lady Visitor be required to contribute Five Pounds in the first week of October in every year in aid of the College funds." In return, each Visitor would be allowed to add their name to one class list. ${ }^{156}$ This letter again demonstrates Reid's tendency to

\footnotetext{
${ }^{153}$ The idea that competition was unhealthy for both girls and women was fairly common at this time, and was one of the major objections against women entering the more prestigious Universities, which will be discussed in the next chapter. Ibid, 78-79.

154 Ibid, 79.

155 Elisabeth Jesser Reid entry in Lady Visitor Log, January, 1852, in Tuke, 80.

${ }^{156}$ Elisabeth Jesser Reid to Lady Visitors, April 30, 1852. RHUL Archives, RF 103/2/24.
} 
speak without giving thought to others and of her zeal outrunning her discretion. To her, an independent woman of means, it was not unheard of to make such a donation as "they likely spent as much without question upon their circulating libraries and other amenities of life." ${ }^{\prime 157}$ While this may have been true, the Lady Visitors did not take kindly to being addressed in such a manner and sent a severe letter in reply in which they stated the matter needed to be taken before the Board. The Board agreed and a Committee was appointed to answer the question. They determined a sum of $£ 230$ a year, in addition to student fees, was necessary to keep the College from closing. The Committee did not make donations either from the Lady Visitors or the Professors mandatory, as Reid desired, but strongly suggested they do so for the "Great and Good Cause." ${ }^{158}$ While not all of those called to make donations did so, enough funds were contributed so that the College managed to stave off bankruptcy for a while longer.

With the difficulties of securing funds and recruiting pupils and the conflicts between the Lady Visitors and the Professors somewhat resolved, the Council turned its attention to other problems, specifically the lack of education of the incoming students. As mentioned above, the level of education girls received was markedly lower than their male counterparts. Very few of the girls registering for classes at Bedford were able to understand the higher level of education and ideas offered, often frustrating their professors. As per Reid's wishes, there was no entrance examination for new students or any specific minimum amount of education they were required to

\footnotetext{
${ }^{157}$ Ibid.

${ }^{158}$ Tuke, 82-83.
} 
possess. ${ }^{159}$ Faced with the resignation of several professors and the difficulties of recruiting new one who would be willing to work with markedly under-educated pupils for far lower pay than they were accustomed to, the Council was forced to take action. Instead of implementing an entrance exam, they decided to provide the necessary education required for students to perform at higher academic standards. In 1853, under the tuition of Francis Martin and Jane Benson, the Bedford Junior School was established. ${ }^{160}$

The School was designed as an institution to provide girls with an education that would bridge the gap between the elementary level they received at home and the advanced level they sought at Bedford. Girls as young as nine were accepted into the new institution, and received instruction in "History, Writing, Arithmetic, Geography, French, Latin, Vocal Music and Drawing," from a Lady Superintendent "acting with the Professors in the Corresponding departments in the College." ${ }^{161}$ Although the notion behind the School was sensible, it failed to have the impact Reid and the Council hoped it would. Within a few years after its opening, minutes from a Council meeting illustrate their frustration with the new endeavor, stating that, "very few pupils from the school proceed to the higher classes." ${ }^{\prime 162}$ Eventually the School began to show more impressive results, with more students continuing on to the College, and

\footnotetext{
${ }^{159}$ Busk, 8-9.

${ }^{160}$ Martin was educated at Queen's College, and was the Superintendent at Bedford School from 1853 to 1869 . Afterwards she worked closely with the Women's Working College, founded in 1864, acting as both Honorary Secretary and then President in 1910. Following her death in 1922, the Women's Working College was renamed after her and she is remembered as one of its key founders. Far less is known of Benson, who was a close friend of Martin and held the title of "Second Mistress" at Bedford School. Crook, 19; Tuke, 84, 308.

${ }_{161}$ Prospectus of Junior School. RHUL Archives, RF 155/1/1.

162 Ibid.
} 
began generating a small profit. This progress, while slow, is another indicator of the middle class's desire to improve the education of their children. For while women might have been able to enroll in Bedford on their own, girls as young as nine would not have been able to attend the School without the consent and approval of their parents. This support of the middle class would become a defining characteristic of Bedford and the women's higher education movement as a whole, which would eventually result in the successful foundation of additional colleges for women and improved schooling four young girls, which will be further discussed in the next chapter.

By now, most of the significant problems of the College had been managed, with the exception of the differences in opinions between the Lady Visitors and the Professors. In the years following these first tumultuous five years, the Ladies' College at Bedford Square experienced a period of calm, with only a few minor incidents occurring. In 1856, the Council decided it would no longer allow students to choose whichever lectures they desired. Instead, they created a course of study that would regulate student's studies and ensure they received a balanced course load. The schedule adopted by the Council included four years of history and three years of Latin, with a choice of "not less than three additional subjects each year," of Modern Languages, Mathematics, Natural Philosophy or English Literature. ${ }^{163}$ The Council also made an important distinction among those enrolled in the College. From this point forward, all those who followed the four-year plan would be referred to in all

\footnotetext{
${ }^{163}$ Council Minutes, April 20, 1856. RHUL Archives, 157/3/26.
} 
official documents as "students," while all those who chose to continue attending lectures of their desire would be deemed "pupils."164 The development of a four-year planned course of study was an important step for the College. Whereas the actions of Bedford's Council had previously indicated a sense of impermanence, this development displayed their faith in the future of the College. The establishment of a regulated curriculum also demonstrated a developing confidence in their student's ability to handle a four-year schedule. This new set of courses was also a method of encouraging students to enroll in more classes for extended periods of time, as opposed to attending sporadic lectures for a short time.

Also in 1856, the Council received a letter from Queen's College, requesting a delegation from Bedford to attend a conference to "agree upon some united course of action concerning the Ladies' Colleges."165 Although Queen's had had a number of advantages upon its opening, at the time they sent the letter, they were facing a budgetary crisis similar to that which Bedford had experienced. As neither college was excelling in either profit or attendance as much as they had hoped, the administrators of Queen's felt the most practical and profitable solution was a merger of the two institutions. Though there is a record of the proposal being drafted and a record of it being received, there is no record of the proposal ever being considered by Bedford's Council. ${ }^{166}$ The issuing of this proposal demonstrates an acceptance by the Anglican Queen's College of Bedford and its unorthodox methods, as well as an

\footnotetext{
${ }^{164}$ Ibid.

165 Tuke, 87.

${ }^{166}$ Kaye, 57-59; Tuke 87-90.
} 
acknowledgement of Bedford's success. While the combining of the Colleges might have been beneficial in the short term, there is little doubt the conflicting ideologies between Queen's and Bedford would have eventually been detrimental to both. In any case, Bedford slowly began to thrive in the following years, as did the burgeoning women's higher education movement. The continuing success of Mrs. Reid's College gave further momentum to this movement, as it continued to gain attention and support throughout the 1850s and 1860s. Those educated at Bedford, served as evidence that advanced knowledge was not harmful or detrimental for women, and often continued the campaign for women's higher education, as did Bedford's supporters and Lady Visitors, giving the movement more influence and giving more confidence to the middle class.

The period following the first decade of the Ladies' College at Bedford Square saw the arrival of Emily Davies, who was closely involved with Bedford and slightly less so with Queen's. Yet, Davies quickly became dissatisfied with the direction of the two early Colleges, and decided to establish a new institution in the fashion of the colleges of Cambridge and Oxford Universities. ${ }^{167}$ Before she attempted the immense challenge of campaigning for equal education, which will be discussed in the next chapter, Davies and a number of other prominent like-minded women set their sights on reforming schools for girls and campaigned for women to be allowed the right to take part in the Cambridge and Oxford local examinations. Davies and her contemporaries' participation in such campaigns for equal education demonstrates

\footnotetext{
${ }^{167}$ Ann B. Murphy and Deirdre Raftery, eds., Emily Davies Collected Letters, 1861-1875. (Charlottesville: University of Virginia Press, 2004), xix-li, passim.
} 
another way in which women were entering and engaging the public sphere. While their actions are a result of the continuing momentum created by the earlier social ferment, they also represent an entirely new direction for the women's higher education movement. Davies' campaign for access to the local examinations was far more aggressive than any action previously undertaken by the movement, and would serve to increase the fervor as well as the number of the supporters for the women's higher education movement.

Like the middle class and the governesses a decade prior, Davies first focused her attention on the teachers of English schoolchildren and the quality of their education. In the late 1850s, both Cambridge and Oxford established local university examinations for the purposes of measuring the achievements of schoolboys who were not going on to University, but whose employers wanted to know what knowledge they had gained at school. Davies felt these examinations should be offered to schoolgirls as well, not only for their own satisfaction, but also to measure the effectiveness of their teachers. ${ }^{168}$ She gathered support for her fight from the National Association for the Promotion of Social Science (NAPSS) and from the Society for the Promotion of Education for Women (SPEW). Through the use of several requests and the financial backing of a number of influential men, Davies and her followers were ultimately able to persuade Cambridge to open their local examinations to women in 1864 on a trial basis, so long as the modesty of the women in question could be preserved. In 1867, following a few years of adequate results for the women and the

\footnotetext{
${ }^{168}$ Burstyn, 24-25.
} 
university authorities, the examinations became permanent for women. ${ }^{169}$ Women's access to these examinations was a breakthrough for Davies and for the higher education movement. Teachers gained insight into how best to improve their techniques and Davies gathered the contacts and support necessary to continue her campaign for equality in women's education. This support came from wealthy influential investors, as well as a large number of middle-class women who desired better education for their children and themselves.

The achievements Davies and her associated made were monumental strides for the advancement of women's higher education, made possible due to the earlier work of Elisabeth Reid and her fellow founders. Not only did Bedford help introduce the idea of women in a college setting to middle-class society, but many of the women who campaigned for access to Cambridge's examinations had been connected to the College, as Lady Visitors, founders, or students. Though it would take several decades before Davies' visions of total equality in education could be fully realized on a large scale, the accomplishments of Bedford College helped further her plan, by giving additional motivation to the women's higher education movement and by raising the level of education for many young women, especially in the years following Reid's death and during the subsequent leadership of the Trustees.

While Davies was beginning her work with the women's higher education movement, Bedford College was experiencing beginning its second decade. If both Elisabeth Reid and Margaret Tuke categorized the first decade of Bedford's existence

${ }^{169}$ Robinson, Bluestockings, 41-43. 
as a "hurricane," there can hardly be words to describe the storm that hit in the next. At first, it seemed the College was doing well, in both students and finances. This prosperity was due in large part to the success of the Junior School in maintaining a steady average of sixty students, which added anywhere from $£ 1,000$ to $£ 1,200$ in revenue to the College annually by 1863 . Other signs of the prosperity of the College included increased scholarships and donations, the inclusion of terminal examinations, an increased number of resident students and for the first time since the opening of the College, a year (1862-63) without any changes among the professors. ${ }^{170}$ These developments were another manifestation of the increased acceptance of women in higher education by students, parents and outside sources. However, these advancements would prove to be short lived, as Bedford would soon face new challenges as a result of the loss of an important member of their community.

By the early 1860s, Reid's failing health prevented her from participating in the affairs of the College as much as she desired. Many of the letters she received at this time reflect her friends' concern for her health and go as far as to suggest she resign from her College entirely in order to save her strength. In 1865, Elizabeth Bostock wrote to Reid, expressing her sympathies over her friend's ill health and remarking, "I fear that you let the College troubles pray on your mind, but let us do our best, the result must rest with a higher power."171 Though she refused to withdraw from the College entirely, Reid's poor health eventually forced her to take a less active role in the daily administrative operations of Bedford. In light of her absence, Bostock,

\footnotetext{
${ }^{170}$ Tuke, 90.

${ }^{171}$ Elisabeth Ann Bostock to Elisabeth Jesser Reid, 1865. RHUL Archives, RF 103/1/29.
} 
Jane Martineau and Eleanor Elizabeth Smith interceded. All three women had been closely involved with the College since its beginning and their responsibilities had grown after the first decade. In 1860, Reid invested $£ 2,000$ in the College by establishing a Trust, which was used to lease a Boarding House for the Resident students. The funds were only given on the stipulation that Bostock, Martineau and Smith be established as Managers. ${ }^{172}$ In this way, Reid was guaranteeing the College would be managed as she had always desired, with women taking a commanding leadership role. Reid relied heavily on all three women throughout the last years of her life, during which the College took another downturn, which was not a reflection of the management style of Reid Trustees, but rather the ongoing conflicts between these women and the men of the Council. Other complications would also contribute to this recession, and would cause a rift in the Council that could only be resolved by a complete change in administration.

In 1864, Bedford Junior School and its principal Francis Martin were under intense scrutiny by the Council. Expenditures had once again begun to exceed income for the College as a whole and a special committee was appointed to look into the matter. While this committee eventually decided that raising student fees was necessary to compensate for the lack of income, they also discovered an alarming discrepancy between the students in the Junior School and those in the College. The committee and the Council accused Martin of keeping girls in the School when they were capable of entering the College, as well as failing to provide adequate teaching

\footnotetext{
${ }^{172}$ Bentley, 10.
} 
that might have helped others to reach the College. Martin denied these allegations, and claimed the Council and its Committee had no right to investigate the School, asserting that prerogative fell under the purview of the School's Councilor, Eleanor Elizabeth Smith. ${ }^{173}$ The matter of the students was eventually resolved, though there was still quite a bit of friction between the School and the Council, most of which seems to have centered on the lack of an official agreement or contract between the two institutions. ${ }^{174}$ Reid, who often failed to see the need to involve the Council in regards to her College, had made all the arrangements for the School with Martin alone. In order to relieve remaining tension and prevent future problems, the Council decided it would be necessary to create a constitution. ${ }^{175}$ During the last few months of 1865 and the beginning of 1866, the Council had several debates and drafted numerous versions of a Constitution for both the College and the School. However, in the midst of this process, on April 1, 1866 at the age of seventy-six, Elisabeth Jesser Reid died. While the foundress had not been personally involved in the creation of this new Constitution, her death marked the beginning of a dramatic shift in the management and administration of her College.

For all her contributions, monetary or otherwise, the passing of Bedford's founder received little recognition from the Council save for the cancelation of a party the Lady Visitors had scheduled at the College. The Board did little better in the brisk

\footnotetext{
${ }^{173}$ While Tuke comments that the evidence she produced in her favor was less than convincing, she fails to mention exactly what this evidence was, or how it was inadequate. Tuke, 95-97.

${ }^{174}$ Again, neither Tuke nor Crook mentions how the issue of the students was resolved, or what changes were made. Tuke, 96-98; Crook 20-23.

${ }^{175}$ While a Constitution had been drafted when the College first opened in 1849, it was never formally adopted by the Board. Busk, 17.
} 
and curt message they sent to Reid's sister, Mary Sturch. ${ }^{176}$ Nevertheless, her close friends, acquaintances and even those whom she might have considered rivals or adversaries saw her death as a tragedy. On the day of her funeral, Henry Crabb Robinson remarked that Reid, "was one of the present, and made both friends and foes by her zeal which sadly outran her discretion." ${ }^{177}$ The Professors finally proposed a memorial for Reid in the form of an entrance scholarship or an exhibition. However, while the Council approved both ideas, Sturch disapproved of an exhibition for her sister. ${ }^{178}$ Though little was done to commemorate the life and work of Reid in the years following her death, the foundress had done much to ensure the College would continue to thrive long after she was gone, most significantly through the establishment of the Reid Trust.

In 1860, as her health was starting to deteriorate, Reid had founded the Trust with her donation of $£ 2,000$ for a Residency House, as mentioned earlier. Reid wrote a letter to her designated managers, Bostock and Martineau, in the same year, in which she outlined the particulars of the Trust, her reasons behind its establishment and installed them as Trustees.

There is a very solemn feeling at ending any act that will not come into force till after my death...All I can do is secure for my Executors those who I believe to be likeminded with myself, who have the same great and good Cause at heart via: - the elevation of the moral and intellectual character of Women. ${ }^{179}$

\footnotetext{
${ }^{176}$ Bentley, 11; Crook, 33.

${ }^{177}$ Henry Crabb Robinson, “April 6, 1866” In Hudson, 317.

178 Tuke, 98-99.

${ }^{179}$ Original Emphasis. Elisabeth Jesser Reid to Jane Martineau and Elizabeth Ann Bostock, 1860, in Tuke, 316.
} 
In addition to naming the two women as Trustees, she demanded they appoint a third within three months of her death, "to share in all your powers and labours, and bound likewise to secrecy." ${ }^{180}$ Frequently frustrated at the Council's subversion of efforts to allow women to have a strong leadership role in the administration of the College, Reid's decision to place the financial control in the hands of the women of the Trust ensured their voice and their position in the future of Bedford. Requiring secrecy from the Trustees, Reid further ensured that no one from the Council, especially the male members, would have the opportunity to circumvent her plans, as many still strongly objected to the notion of female leadership. While this objection had been based on the general lack of experience of the women of the Council, Reid viewed it as a slight against her personally. Reid's resentment, along with the more than fifteen years of experience gained by Bostock, Martineau and Smith (the third Trustee), no doubt let the foundress feel justification in her secret decision on the future of Bedford's leadership.

A second stipulation was also demanded of the new Trustees, as well as of any future members. "If either of the Three marry...it will only be just to resign the Trust to other hands." ${ }^{181}$ Banning married women from these positions ensured that women, not men, would be in control of her College, as she likely feared any husband would force his opinion over than of his wife's. While it is possible this fear stemmed from the traditional characteristics of a Victorian marriage, it may also be an indication of

\footnotetext{
${ }^{180}$ Elisabeth Jesser Reid to Jane Martineau and Elisabeth Ann Bostock, 1860, in Tuke, 317. Although Reid stated Bostock and Martineau should appoint a third member to the Trust within three months after her death, Reid herself appointed Eleanor Elisabeth Smith in August of 1860. Ibid, 318.

${ }^{181}$ Ibid, 318.
} 
the nature of Reid's own marriage, though there is no documentation to support this speculation.

Upon her death, a Codicil to her Will completed the Trust, and declared that a sum of $£ 16,400$ was to be distributed annually in $£ 800$ shares "for the benefit of the [Ladies' College at Bedford Square] and the promotion and improvement of female education therein." The Will went on to name Bostock, Martineau and Smith as sole executors of the Trust, as well as name all three women as the owners of the leases of both houses of the College. ${ }^{182}$ The control of such a vast fortune and the grounds of the College gave these women an incredible amount of authority over both the Board and the Council and it was quickly apparent Reid had chosen the future leaders of her College wisely.

The first act of the Trustees was to demand the Council hire an outside examiner to inspect the School and the College in order to offer an impartial opinion on what improvements were necessary for their continuing success. They also ordered the Council to forward all measures or resolutions to the Trustees for final approval. This ensured the College would remain true to Reid's original vision, including its non-sectarian character and high standards in teaching. ${ }^{183}$ While not all members of the administration of Bedford were pleased with the new heads of the College, there was little they could do to protest. The survival of the College was dependant on the funds received from the Reid Trust; without its support, the College would be forced to close.

\footnotetext{
182 “Last Will and Testament of Mrs. Elisabeth Jesser Reid," RHUL Archives, GB 100/1/2.

183 Tuke, 100-106.
} 
The hiring of an outside examiner was protested above all other actions taken by the Trustees, causing one Professor to resign his position in protest. ${ }^{184}$ The Trust chose James Bryce, an Assistant Commissioner of the Royal Commission on Middle Class Education who was supremely qualified to examine the women at Bedford. Although no copy of Bryce's report survives, it is evident from the protestations that arose from a handful of professors as well as Francis Martin that the report was less than complementary of many classes, and of the School as a whole. The report caused a rift in the Council, with some siding with the Reid Trustees and other with the School. After several rounds of heated debates, the Council, with the express approval of the Trustees decided on March 11, 1868 that the School would be permanently closed at the end of the term. ${ }^{185}$ While many in the administration of the College were reeling from this decision, the Trustees forged ahead introducing a new proposal three months later that would change the organization of Bedford even more radically. On June 27,1868 , the women of the Trust presented a proposal to the Board, in which they stated they were prepared to take over all actions and responsibilities of the Council, "for one year in order that [the College] may be placed on a satisfactory footing." 186 Though many members of the Board expressed their protestations, in the end they conceded. They had no other options and by the beginning of July, the Council had been dissolved.

\footnotetext{
${ }^{184}$ Professor George Macdonald of English Literature gave his resignation to the Council, citing that "he would not stay to see his classes examined by any one but himself." Ibid, 102.

185 Busk, 20.

${ }^{186}$ Elisabeth Ann Bostock and Jane Martineau to Erasmus Darwin, June 27, 1868, in Tuke, 328-329.
} 
Despite Tuke's usage of the terms "mutiny" and "coup d'état" to describe this period in Bedford's history, it is apparent this shift in administration was greatly beneficial to the College's continued success. Without the hindrance of the infighting to which the Council had been prone, the Trustees managed to draft a new Constitution for the College within a year, and it was accepted by the Board in June of 1869. ${ }^{187}$ This new document outlined the creation of a new Council, the members of which were to be elected from "the members of the College," adding that "no Professor, teacher or other paid officer of the College... [was] to be eligible as a member either of the College or the Council." ${ }^{\prime 18}$ This provision would prevent much of the bickering and self-promotion that had plagued the first Council, as well as settling any friction between the Professors and the Lady Visitors. With these new provisions set in place, the Ladies' College of Bedford Square, which was renamed Bedford College under the new Constitution, was set to face the next twenty years, keeping well in mind the trials and tribulations it had experienced in the first twenty.

When Elisabeth Jesser Reid first set into motion the lectures, correspondences and ideas that would eventually result in Bedford College, it is clear that in her mind there was little doubt as to how successful the College would be, or how much influence it would wield. Even after the low attendance rates and diminished finances suffered in the first few years, Reid remained hopeful that the potential of her institution would soon be realized. "One thing is certain," she wrote, "that the condition of women was never quite so good, or by great deal so hopeful as at this

${ }^{187}$ This process was also known as the Incorporation of the College. Ibid, 103.
${ }^{188}$ Article 38 of the Constitution, in Calendar, 35 . 
moment... [and] by untiring efforts and extreme patience we may, with God's blessing, obtain a glorious result in a quiet unobtrusive resistless success." ${ }^{189}$ Yet Reid had a different definition of success than the likes of Emily Davies and others who would establish colleges for women in the years to come. For the founder of Bedford, success did not mean that her students were learning the exact same skills as men were, or that they were using their education to find careers out in the public sphere. Instead, Reid viewed success as women gaining knowledge that they could pass on to their children or use in such a way that made them better helpmates for their husbands. While the exact motivations behind Reid's desire to open a college for women remains unclear, much insight can be gained through the examination of her childhood, her faith, and ultimately her assessment of the success or failure of the College.

The path forged by Reid and Bedford was hard and difficult, made all the more so by the lack of precedents. As this chapter asserted, the work done by Reid and the other members of the Council, including securing donors, finding professors and students and drafting a prospectus for a woman's college allowed for the easier passage of those who followed in the women's higher education movement. In the years to come Emily Davies and others would go on to establish colleges for women affiliated with Cambridge and Oxford Universities, though despite their best efforts they would be unable to secure degrees for women at either institution in their lifetime. Bedford on the other hand, with the help of the University of London would

${ }^{189}$ Elisabeth Jesser Reid to Elizabeth Ann Bostock and Jane Martineau, 1860, in Tuke, 316.d 
soon begin granting degrees to women and further reinforce itself as a pioneer for women's higher education. 
Chapter Three: "The Larger Light of Experience":

Bedford College and the Foundation of the Other Women's Colleges, 1869-1900

Should I not call her wise, who made me wise?

And learnt? I learnt more from her in a flash,

Than if my brainpan were an empty hull.

And every Muse tumbled a science in.

-The Princess, Act II

When Emily Davies opened the doors to her college for women in 1869, Bedford College had already experienced twenty years of trials and tribulations, often appearing on the brink of closure and bankruptcy. These turbulent decades were described by Margaret Tuke in her History of Bedford College for Women in terms such as "Hurricane," "Headwinds" and "Mutiny and The Mutineers." In contrast, the terms "Flow \& Ebb," "The Tide Turns" and "In Port" are used to describe the prosperous thirty years that followed, at which point Bedford was incorporated into the University of London. Although these depictions are rather romanticized, they accurately portray the contrasts between the two periods. This final chapter will focus on the years following the death of Elisabeth Jesser Reid and the shift in management from the Council to the women of the Reid Trust, during which Bedford experienced a phase of growth and prosperity. While this prosperity can be largely credited to the new administration of the Trustees, other factors, such as the establishment of the women's college associated with Cambridge and Oxford and the growing women's higher education movement must be considered.

While many were satisfied with the direction being taken by Reid and the other members of Bedford, a few outliers began to push for more drastic measures. Emily 
Davies, herself at one point a member of Bedford's Lady Visitors, felt Bedford was heading in the wrong direction and set her sights towards creating a college where women would receive the same education that was given to the students of Cambridge University, not a modified version fitted to suit less-learned women. ${ }^{190}$ It is here that Davies and Reid most differed in their actions and philosophies on women in education. While Reid desired to educate women to become better mothers, Davies was actively campaigning for women's education to be adequate enough that women might be able to enter into the workforce and move beyond the private sphere. In this spirit, Davies would work to establish Girton College and would campaign for women to be allowed to sit for examinations for degrees at both Cambridge and Oxford Universities. Though Davies would dismiss the quality of the education provided by Bedford, it was the earlier college's establishment that provided an entry for women into the arena of higher education.

The idea of women in higher education, a notion that Bedford had been promoting in the face of some criticism since its founding, was now being discussed on a much larger scale. Yet while the movement to establish colleges at Cambridge and Oxford was just beginning, Bedford was continually growing and maturing, adding more advanced courses, student groups, and sports and social clubs. These additions served to attract more students, further increasing enrollment and income for the College, which in turn generated more support and attention for the women's higher education movement. With both Cambridge and Oxford slowly warming to the

\footnotetext{
${ }^{190}$ Burstyn, 50-75.
} 
idea, many in England became aware that the vague notion of women in colleges and universities was rapidly becoming a reality. Although the foundations of the new institutions prompted a great deal of criticism, they also generated a fair amount of publicity for the women's higher education movement and for Bedford, which in turn added to the increasing population of female students.

In 1870, four years after the death of Reid, Bedford was having difficulty adjusting to the new administration of the Trustees, experiencing its lowest student enrollment numbers and an income only half of what it had been a decade earlier. ${ }^{191}$ In light of these discouraging figures, the women of the Reid Trust, Elizabeth Ann Bostock, Jane Martineau and Eleanor Elizabeth Smith, hired a number of new Professors and secured several prominent men to serve on the new Council, most of whom were connected with Oxford University. ${ }^{192}$ Though the appointment of these men drew heavily on the College's already stretched funds, it was a highly political and astute move for the Trustees. By hiring these well-known and renowned scholars, not only were they linking Bedford's name with the stature of Oxford, they were also competing with Emily Davies' newly established College at Hitchin, Hertfordshire. Following the appointment of these professors and Council members, student enrollment began to increase, as did the College's annual income. While Tuke credits a "large measure" of this influx to the new hires, she fails to consider events occurring

\footnotetext{
${ }^{191}$ Tuke, Chart II, n.p., Chart V, n.p.

${ }^{192}$ These new hires included, among others, Ingram Bywater, a notable Professor of Greek and a wellknown scholar of Aristotle, Heraclitus and Priscianus Lydis; Mervyn Herbert Nevil Story-Maskelyne, a founder of Oxford's School of Mineralogy and a Keeper of Minerals at the British Museum; and John Wesley Hales, who was educated at Glasgow University and Christ's College, Cambridge before he was hired as a Professor of English at King's College, London and Bedford College. Ibid, 120-124, 301-313.
} 
outside the walls of Bedford, especially the founding of the other women's colleges and the growing popularity and influence of the women's higher education movement. ${ }^{193}$

By 1874 , the College's annual income was nearly $£ 3,000$, a figure that was well over double any previous income, and student enrollment, which had been less than fifty only four years earlier, was just over $130 .{ }^{194}$ The College was growing so rapidly that it became necessary for the Trustees to look for other premises. While this search was originally intended to be only for more housing for resident students, the College lost the lease for the Bedford Square property and was forced to search for an entirely new location. ${ }^{195}$ In their search for new accommodations, the Council and the Reid Trustees faced many of the same problems Elisabeth Reid had encountered nearly twenty-five years earlier. The new property needed to be large enough to accommodate the influx of students and in a respectable enough neighborhood that it would not be too difficult a commute for either professors or students. Unlike Reid's original search, this time the Trustees had access to far greater resources and were able to consider locations that had previously been beyond Bedford's means. Eventually the Trustees, with the unanimous support of the Council chose two houses at 8 and 9 York Place, which were "a part of the east side of Baker Street, just north of Paddington Street" and only a short distance from Regent's Park. ${ }^{196}$ These new buildings were far more attractive than the College's previous location and with slight

\footnotetext{
${ }^{193}$ Ibid, 121.

${ }^{194}$ Tuke, Chart II, n.p., and Chart V, n.p.

195 Ibid, 122.

196 Bentley, 12.
} 
modifications, the larger structure was able to accommodate new laboratories and bigger lecture halls and classrooms, as well as more comfortable residence rooms than had been available at Bedford Square. ${ }^{197}$ The purchase of a new lease and the move to a more upscale neighborhood worked greatly in Bedford's favor. Just as the acquisition of more prominent and learned Council members and Professors had done, Bedford's new locale served to increase both income and student enrollment. In the next four years, the annual income of the College would average close to $£ 4,000$, and the number of students would rise steadily to an average of 150 per year. ${ }^{198}$ The rising enrollment at Bedford, as well as the establishment of two women's colleges associated with Cambridge University gave new strength and momentum to the women's higher education movement, whose members began to campaign for even more advancements, specifically for the right to sit for and be awarded official university degrees.

One of these members was William Shaen, a non-conformist who had married into a well-known Unitarian family. ${ }^{199}$ He was a member of Bedford College's Council for nearly twenty-five years, and a benefactor of Girton, Newnham and Somerville, three of the four newly established colleges at Cambridge and Oxford, and

\footnotetext{
${ }^{197}$ While the Trustees, the students and the Lady Visitors might have enjoyed their new home, the Professors found the accommodations impractical and bothersome. The Central Hall, where the students and the Visitors gathered before and in-between classes, was deemed off-limits to the Professors for the sake of propriety. Therefore, in order to reach their classrooms, these Professors had to navigate downstairs to the basement, walk under the Hall and emerge up the stairs on the other side. So many Professors protested the inconvenience that the Council "regretfully' gave them permission to pass through the Hall when 'absolutely necessary'." Tuke, 124-125.

${ }^{198}$ Tuke, Chart II, n.p., and Chart V, n.p.

${ }^{199}$ Bentley, 25.
} 
had helped to establish the London School of Medicine for Women. ${ }^{200}$ Yet, despite all these accomplishments, his most significant contribution to the women's higher education movement was his enthusiastic and tireless campaign for women's access to degrees at the University of London. With the assistance of Henrietta Busk and her brother Edward, Shaen worked diligently until the University finally agreed to confer degrees upon women in $1878 .{ }^{201}$ At this time, the University of London was only a degree-granting body, and not a teaching institution. As such, no students were enrolled at the University of London, and no lectures given. Students completed all course work at a partnering college, before they would apply to the University for a degree. In January of 1879 one current and three former students of Bedford College completed the first Matriculation Examination, with five more to follow in the coming June, making them the first women in England to be granted Bachelor of Arts (BA) degrees. ${ }^{202}$ However, this historical milestone has been vigorously challenged by Emily Davies and modern scholars of the history of women's higher education.

In the promotion of her own college, Emily Davies repeatedly dismissed Bedford's methods of education and the degrees given by the University of London, as being substantially inferior to those given by Cambridge. One of Davies' first articles,

\footnotetext{
${ }^{200}$ Tuke, 312-313.

${ }^{201}$ Henrietta Busk was a student first of the Bedford Junior School in 1854 and a student of the College from 1861 to 1864 . She became a member of the Council between 1882 and 1885 and again from 1889 to 1936, as well as President of the Bedford College Old Students' Association from 1926 to 1928. She wrote a brief history of Bedford College in 1899 to commemorate both the fifty-year anniversary, and its upcoming incorporation as a member of the University of London's collegiate system. It is interesting to note, that not only does Busk make no mention of her or her brother's involvement in the fight for women to be granted degrees, she also hardly gives the monumental achievement any mention. It also does not appear that Busk took advantage of what she fought so hard for, as there is no record of her ever being granted any sort of advanced degree. Cf. Busk, especially 15-17; Tuke 125-128, 301.

${ }^{202}$ Busk, 16.
} 
"University Degrees and the Education of Women," published in 1863, illustrates the exact nature of a degree and what value it held for women. In this article, written several years prior to the University of London's decision to grant degrees to women, she compares the degrees of that institution to those given by Cambridge and Oxford. Davies asserts that the degrees given by the University of London were substandard, as the men of Oxford and Cambridge were constantly learning and gaining knowledge over the course of two to three years, while the same could not be guaranteed of graduates of the University of London. "It is possible that a young man, preparing at home for his degree, may be sufficiently crammed to pass, and may even find his name somewhere in the list of honours; and yet mistake knowledge for wisdom and a retentive memory for genius." ${ }^{, 203}$ In her usual blunt manner, Davies implies that degrees granted to students by an institution they did not attend for a certain number of years were substandard to those granted by a residential teaching university.

It is interesting to note that Bedford is not mentioned specifically in this article and Queen's College is used instead as an example of why women should be allowed degrees. Davies further examines the education of the men who were receiving BA degrees and questions the level of danger it would present if women with the same education were allowed similar privileges.

It is by no means obvious that it would do women any harm to know enough for the B.A. (London) pass-examination. They are already expected to learn not much less at Queen's College, in Harley Street; and a degree would be to women, in their present stage of cultivation, what honours are to men. ${ }^{204}$

\footnotetext{
${ }^{203}$ Ibid, 41-42.

${ }^{204}$ Ibid, 55.
} 
The mention here of Queen's and the omission of Bedford College is an important insight into Davies's views of Reid and her College. Though she was a Lady Visitor and served on a number of committees as Bedford, Davies eventually came to disdain the methods of the College and its Professors, as she felt the education given to Bedford's students was unjustly modified and diluted for women, instead of giving them the same knowledge as men. Yet she ignores the monumental strides made by Bedford that would make the foundation of her own institution possible. Davies' dissatisfaction with Reid and her College was so great that she made several veiled biting comments about Bedford in her published proposal for her own women's college. $^{205}$

Davies' displeasure with the level of education given to the students at Bedford College is also present in the work of modern scholars. In her acclaimed and groundbreaking work No Distinction of Sex?: Women in British Universities, 1870-1935, Carol Dyhouse warns that a straightforward timeline of events in women's higher education is nearly impossible to produce. "The pattern is complex, and much depends on definitions. Neat chronological lists of dates of entry are not easy to draw up and can often be misleading. ${ }^{206}$ However, Dyhouse almost seems to make the time line and her definitions more complicated than they actually were. For instance, she notes that St. Andrews University in Scotland began awarding special Lady's Literature in Arts (LLA) Certificates to the few women who had been permitted to sit in on lectures

\footnotetext{
${ }^{205}$ This will be discussed in further detail later in this chapter. Cf. Emily Davies "Proposed New College for Women" in Davies, Questions.

${ }^{206}$ Dyhouse, 12.
} 
in 1876, two years before the University of London agreed to confer BA degrees on women. ${ }^{207}$ Yet, as these LLAs were specifically designed for women and not equal to those given to men, they should not be confused or compared with the BAs of Bedford and the University of London. While Dyhouse does mention the University of London's degrees, she echoes Davies in dismissing them as inferior to the BA degrees to come, due to their recipients' being educated at a separate institution. Also, although her book is an incredibly valuable piece of scholarly work and an important addition to the field, Dyhouse's decision to focus on women in higher education after 1870 is somewhat disappointing, as such a late starting point fails to include all aspects of the history of women's higher education, including the contributions and accomplishments of Bedford and Queen's Colleges, and the rise of the women's higher education movement. ${ }^{208}$

Jane Robinson also remarks on the quality of education offered at Bedford in her work, Bluestockings: The Remarkable Story of the First Women to fight for an Education, likening it to sixth form schooling. ${ }^{209}$ While this assessment certainly applies to the education offered in the first decade of the College, it should be credited to the lack of previous schooling of the students rather than to any fault of the College or the Professors. Furthermore, the Bedford Junior School was established in recognition of the College's ill-prepared students and steps were taken to improve the education of young girls before they began to take college courses. After the

\footnotetext{
${ }^{207}$ Ibid, 11-15.

${ }^{208}$ In fact, Dyhouse discusses Bedford only a handful of times; Queen's is not mentioned at all. Ibid, 145, passim.

${ }^{209}$ In the British educational system, sixth form education is equal to American High School Juniors and Seniors. Robinson, Bluestockings, 20-25.
} 
University of London's decision to confer degrees upon women, Bedford added extra courses and advanced lectures in physics, biology, German, English and Organic Chemistry to help students prepare for the Matriculation examination. These advancements in the College's curriculum resulted in a number of changes in the demographics of the students, as more women aged 16-20 entered Bedford, and fewer women over the age of 35 enrolled. ${ }^{210}$ This shift in the composition of the College is yet another indicator of the rising demand and acceptance of women in higher education from the middle class.

While the decision to confer degrees upon women by the University of London had a significant impact on Bedford and the women's higher education movement, it was not the only outside influence that dramatically affected the College. Between the years of 1869 and 1879, four other women's colleges would be established with Girton (1869) and Newnham (1871) Colleges in association with Cambridge and Lady Margaret (1878) and Somerville (1879) Halls with Oxford. ${ }^{211}$ These institutions were established with very different methods and motivations than Bedford, with founders radically dissimilar from Elisabeth Reid. Yet despite these differences, it is clear the earlier establishment of Reid's College influenced the founding of these later institutions, just as the women's colleges of Cambridge and Oxford subsequently had a substantial impact on Bedford.

For the first of these later women's colleges, Bedford's influence is best seen in the founders' immediate attempts to distance themselves from the earlier college.

\footnotetext{
${ }^{210}$ Tuke, 126-130.

${ }^{211}$ Ibid, 127.
} 
Just as the childhood and early life of Elisabeth Reid provide insight to her motivations and reasons for founding Bedford College, so too can the life of Emily Davies help explain her desire to establish a college for women that was equal to those of men. Sarah Emily Davies was born in 1830 in Southampton, the fourth child and second daughter of the Reverend John Davies, the founder of a local boarding school for boys. Despite her father's occupation, Davies' education was limited to a few months at a day school for girls, where she learned French, Italian and Music. Her brothers, on the other hand, were allowed into their father's school, and were therefore far better educated. ${ }^{212}$ This inequality in her own education would spark a lifelong mission for Davies, who served on several committees and Boards working toward equality for women in higher education, including the London School Board and the Schools Inquiry Commission. She was also a member of Bedford's Lady Visitors from 1862-1864. Unlike Elisabeth Reid, Davies wrote extensively, publishing over a dozen articles and writing a book outlining her opinions on women in education, not to mention the hundreds of letters written either by her or to her that have been preserved. As such, the motivations and reasoning behind her decision to open a college for women are fairly accessible to modern scholars.

In 1866, Davies published "Some Account of a Proposed New College for Women" in the magazine for the National Association for the Promotion of Social Science. In the same way, the first prospectus of Bedford stated the necessity of its

\footnotetext{
${ }^{212}$ Ibid, xxii-xxiii.
} 
existence alongside Queen's College, Davies begins her article with an explanation for the need of another College for women and the deficiency she expected it to fulfill.

The alleged want is that some provision for the education of women above the age of eighteen, analogous to that afforded by the Universities to young men. That any such provision already exists will probably not be affirmed...It is needless to add, that if such an institution is not to be found in London, it certainly will not be found anywhere in England. ${ }^{213}$

From her statements here, it is clear that Davies does not consider the education given at Bedford to be on a par with the Universities of England, by which she means Cambridge and Oxford. Again, while this is probably true, it is hardly fair of Davies to criticize Bedford for not producing students who could be favorably compared with the students Oxford and Cambridge, as those who were enrolled at the younger institution did not have the secondary education of those at the older Universities. Davies continues the justification of her new venture, stating:

Those who doubt whether University Education is desirable for women...hold that though there are public institution for women like Oxford or Cambridge, superior instruction is provided by private and domestic tuition, or by some other means, for those who want it; or that it might be, in some better way than by the foundation of a College; or that all this talk of education is a mistake. ${ }^{214}$

With the goal firmly in mind to fill this void in women's education, Davies began the process of establishing a college for women that would be equal to the men's colleges of the Universities of Cambridge and Oxford. Girton historian M.C. Bradbrook noted that Davies would not tolerate an "easy second best" and formed a committee with "some of the best Cambridge men" in order to ensure high

\footnotetext{
${ }^{213}$ Davies, "Proposed New College" in Questions, 84-85.

${ }^{214}$ Ibid, 85-86.
} 
standards for her new endeavor. ${ }^{215}$ Unlike Reid, Davies decided not to appoint any

women other than herself to these committees, though she certainly had a fair number

of well-educated female friends willing to support her. While Bradbrook credits this

lack of female presence to Davies' fear such appointments would be considered

controversial, it is easy to speculate her reluctance stems from her time as a Lady

Visitor at Bedford, remembering the infighting that often occurred between the

Council members. While Davies was hesitant to offer her friends official positions in

her College's administration, she often turned to them for advice in her new endeavor, especially Barbara Leigh Smith ${ }^{216}$ and author George Eliot, with whom Davies had a regular correspondence concerning the state of women's education. ${ }^{217}$ Armed with her committees and the advice of her close friends, Davies opened The College for

Women in Hitchins, Hertfordshire on October 16, 1869.

Above all else, Emily Davies demanded those enrolled at her college "follow

exactly the same course as was required of Cambridge undergraduates," thought she

often battled against the students and the dons of the university in order to see her

\footnotetext{
${ }^{215}$ These men included Henry Liveing, Henry Sidgwick, John Seeley, James Stuart, Sedly Taylor, F.J.A. Hort, John Venn, and E.C. Clark. M.C. Bradbrook, 'That Infidel Place': A Short History of Girton College, 1869-1969, (London: Chatto \& Windus, 1969), 22.

${ }^{216}$ Smith was the daughter of a wealthy Unitarian family, with a father who desired his daughter to have a measure of independence, and settled $£ 300$ a year on her in his will. Following her childhood dream to become an artist, she enrolled in drawing classes at Bedford College in 1849. As she grew older, Smith became more and more involved in movements for women's employment and in the movement for Higher Education for Women. In 1857, she married the French doctor Eugène Bodichon, with whom she made a tour of the United States. After this trip, Smith became a passionate advocate for abolition, and also began campaigning for English schools to adopt American educational methods. Ibid, 20-25.

${ }^{217}$ In addition to being a friend of the founders of Girton, Tuke also claims that Eliot was a student at Bedford in 1849, though only for the first term, as she "was not in sympathy with the religious spirit and enthusiastic optimism which animated Mrs. Reid and her friends at that time." However, while there is a record of a Mary Ann Evans, Eliot's true name, attending Bedford in 1849, I have been unable to find any records among numerous biographies of Eliot of her having ever attended the College. Bradbrook, 23; Tuke 280-281; Calendar, 205.
} 
demands met. However, it quickly became apparent how few female students were capable of measuring up to Davies's rigorous standards. In the first two years, fewer than twenty students enrolled in The College for Women. ${ }^{218}$ As no mention of outstanding fees or tuition are made by Davies or Bradbrook, the main reason behind low student numbers was likely the strict academic level insisted upon by Davies. While the demand and interest in women's higher education had certainly increased since Bedford's establishment, it had not increased to the point of women's education being equal to men's, as Davies desired. The low enrollment in her College would persist throughout the end of the nineteenth century, due largely to Davies' unwillingness to compromise her vision of equal education for women. Though this goal was admirable, the low student numbers clearly indicate few women were prepared for such advanced education without additional elementary schooling. Another reason behind the low enrollment might have been the strict moral standards imposed by Davies. In the proposal for her college, Davies addresses objections raised by those who feared women engaged in academic study would have no time for their domestic duties.

Let it be understood that the choice is not between a life wholly given up to study, and a life spent in active domestic duty... For while on the one hand, giving to women the opportunity of a complete education does not mean that they will thereupon spend all their lives in reading, so, on the other, denying them education does not mean that they will occupy themselves in household affairs. ${ }^{219}$

\footnotetext{
${ }^{218}$ Bradbrook, 43-57.

${ }^{219}$ Davies, "Proposed New College" in Questions, 97.
} 
Although many modern historians often label Davies as a "feminist" for her views on equal education, her plans for educating young women were not so dissimilar from Reid's desires for better-educated wives and mothers.

In the early 1870 s, her College was involved in a fierce debate over the religion of its students and whether religious observance should be made mandatory. This is another major point on which Bedford and Girton as well as their founders differed. While Reid and Bedford lost many supporters due to her refusal to adopt orthodox religious practices, Davies and Girton lost supporters for her insistence upon more traditional religious observances. Despite the fact that Davies was raised with a more liberal upbringing than most, and that many of the early supporters of Girton were an assortment of Quakers, Unitarians and Jews, as well as Anglicans, the foundress initially insisted that obligatory orthodox religious observance be written into the Articles of Association. However, in the face of considerable opposition Davies conceded that the observances need not be mandatory. Even so, many of her previous supporters, including Henry Fawcett, John Stuart Mill, Henry Sidgwick and George Eliot withdrew their support and pledges of future funds. ${ }^{220}$ While the withdrawal of such prominent supporters must have disappointed Davies, it did little to dissuade the founder of Girton from her goal of creating a college for women equal to any at Cambridge.

Although it is not acknowledged by Davies or Reid or by the historians of their Colleges, some credit for the prosperity experienced by Emily Davies and her own

${ }^{220}$ Bradbrook, 47-50. 
educational experiment must be given to Bedford and its founders. Twenty years before Girton opened its doors, Bedford had offered middle-class women an entry into the world of higher education and merged with the rising social ferment of women permeating the public sphere to initiate the women's higher education movement. Without these previous advancements, the process of Girton's establishment, including the securing of investors, students and professors and the formation of a working executive committee, would have been radically different. Davies' composition of her Executive Committee is an obvious example of her utilizing the experience she gained while serving as a Lady Visitor at Bedford, as is the relative ease with which she was able to gain investors and support for her new institution.

Following the successful establishment of Girton College, Henry Sidgwick left the executive committee of Girton in 1870 to establish Newnham, his own college for women. Although some argued Cambridge did not need another women's college, Sidgwick felt there were many women living near Cambridge in need of a college education who were unable or unwilling to travel to Davies's college. He began by establishing a Lectures for Ladies program at Cambridge in which women could attend lectures on a handful of "respectable" subjects, sometimes in special session with women only and sometimes with male students, with the female students and their chaperones situated behind a partition and hidden from view. ${ }^{221}$ The program started slowly, with only five students enrolling, far below the numbers Sidgwick had anticipated. He hired Anne Clough to preside over the students, and she immediately

${ }^{221}$ Dyhouse, 91-95. 
set about refining and polishing Sidgwick's vision for women at Cambridge. ${ }^{222} \mathrm{An}$ executive committee was formed, comprised of both men and women already involved in the women's higher education movement. This committee organized lectures for interested young women, as well as special "coaching" sessions for those who needed private tuition to prepare for advanced college courses. ${ }^{223}$ Sidgwick had strongly disagreed with Davies's notions of women being given the exact same education as was given to men, as he believed few women were intellectually prepared for such courses. However, he "deplored the inconvenience and waste of time which might keep an adult woman who had not learned classics or much mathematics at school, studying the beginning of these subjects in school-boy fashion when her mind was more adapted to other studies." ${ }^{224}$ As such, Sidgwick and Clough created a College that fused both ideas of women's education to give their students accelerated short courses designed to fill the gap in their limited schooling before they entered into the advanced college course. This approach proved successful, as the numbers of students grew rapidly after the first year. ${ }^{225}$

Though not official members of the university collegiate system, two colleges for women were now connected with Cambridge, each with different methods and attitudes toward education. Davies and Girton College demanded their students be

\footnotetext{
${ }^{222}$ Clough had helped to found the North England Council for Higher Education and had run a school for young girls in the Lake District. Alice Gardner, A Short History of Newnham College Cambridge, (Cambridge: Bowes \& Bowes, 1921), 1-5.

${ }^{223}$ This Committee included among other, F.D. Maurice, Professor Henry Fawcett and his wife Millicent. Mary Agnes Hamilton, Newnham: An Informal Biography, (London: Faber and Faber, 1936), 20-23.

${ }^{224} \mathrm{Ibid}, 17$.

${ }^{225}$ Margaret Birney Vickery, Buildings for Bluestockings: The Architecture and Social History of Women's Colleges in Late Victorian England, (Newark: University of Delaware Press, 1999), 40-43.
} 
able to take the same university courses as any male student, whereas Sidgwick and Newnham College offered private tutelage and prerequisite courses for the students who were not prepared for such a high level of academia. While Alice Gardner, author of A Short History of Newnham College, notes the "small amount of rivalry at the onset [did] not hinder the progress of the two colleges side by side in co-operation and mutual goodwill," Newnham's higher enrollment rate after five years could not have escaped the notice of either Davies or the dons of Cambridge. ${ }^{226}$ Nevertheless, both Colleges continued a slow and steady climb in income and students, proving there was indeed a demand for higher education among women. This demand was also reflected in Bedford's rising student numbers, as well as in the increasing support for the women's higher education movement, which had since turned its attention towards England's other historical University.

As Pauline Adams states in Somerville for Women: An Oxford College, 18791993, the "arrival of women students [in Oxford]...owed much to the encouragement of individual members of the University, nothing to the University as an institution." 227 In June of 1878, a group of such members, including Edward Stuart Talbot, Dr. George Granville Bradley and Thomas Hill Green, formed the Association for Promoting the Higher Education of Women (AEW) with the aim of eventually establishing a college for women in Oxford. However, the group was unable to form a consensus on the exact goals and purposes of their future institution. Talbot insisted

\footnotetext{
${ }^{226}$ Alice Gardner, A Short History of Newnham College Cambridge, (Cambridge: Bowes \& Bowes, 1921), 18.

${ }^{227}$ Pauline Adams, Somerville for Women: An Oxford College, 1879-1993, (Oxford: Oxford University Press, 1996), 7.
} 
upon a fully Anglican college, while Green desired a college open to women of all religious denominations. Eventually the Association split into two groups, with Talbot establishing Lady Margaret Hall and Green founding Somerville Hall. While both of these institutions were founded by men connected with Oxford, like Girton and Newnham at Cambridge, neither would be officially recognized by the University for many years after their establishment. In many ways, the histories of Lady Margaret Hall and Somerville echo those of Queen's and Bedford College almost thirty years earlier. While Lady Margaret Hall and Queen's were founded by well-respected members of the Church of England for Anglican students, Bedford and Somerville were established by persons who were considered radical and unorthodox by most of society, and who accepted students of all denominations into their College. ${ }^{228}$ Yet, Somerville was associated with Oxford University, which gave the fledging institution a validation Bedford would not be able to obtain for many decades.

In 1879, Thomas Green and his followers opened the doors to Somerville Hall, pledging, "no distinction [would] be made between the students on the ground of their belonging to different religious denominations." ${ }^{229}$ In much the same way as Bedford, this decision cast a shadow of suspicion over the institution, especially in the predominantly Anglican Oxford University. While Somerville was mostly able to overcome this suspicion by hiring a conservative principal who would counteract this image, the shadow of Bedford's unorthodoxy followed Reid's College for most of its

\footnotetext{
${ }^{228}$ Frances Lannon, Lady Margaret Hall, Oxford: The First 125 Years, 1879-2004, (Oxford: Lady Margaret Hall, 2004), 5-30; Gemma Creighton Bailey, Lady Margaret Hall: A Short History, issued on behalf of the Lady Margaret Hall Appeal Fund, (London: Oxford University Press, 1923), 10-18.

${ }^{229}$ Somerville took its name from the recently deceased Scottish scientist Mary Somerville. Minutes of the Somerville Committee, February 7, 1879, in Adams, 11-13.
} 
existence, even after its incorporation into the University of London. ${ }^{230}$ Yet Bedford continued to prosper in spite of its inclusion of students of all denominations, giving more evidence of the growing acceptance of the women's higher education movement.

When Lady Margaret Hall and Somerville were established at Oxford, Bedford College had been successfully operating for thirty years. The struggles and subsequent lessons learned from the earlier institution, as well as the momentum Bedford created for the women's higher education movement played a key role in the success and relatively easy establishments of the Colleges at Cambridge and Oxford. By now, supporters of higher education for women were likely delighted with the progress that had been made; not only were there Colleges for women at some of the most prestigious universities in England, the University of London was conferring degrees upon women and Bedford College was profitably and enthusiastically succeeding. However, such success carried a negative backlash. Now that it had seemingly been proven that the notion of women in higher education was not a passing fad, many of the more conservative members of society were becoming increasingly alarmed and endeavored to prove that educating women would ultimately be detrimental to English society.

Leading the charge against women in higher education was biologist and sociologist Herbert Spencer, who was probably best known for coining the phrase "Survival of the fittest," and psychiatrist Henry Maudsley. Both men attempted to use science as well as so-called conventional wisdom to prove beyond any doubt the

\footnotetext{
${ }^{230}$ Susan J. Leonardi, Dangerous by Degrees: Women at Oxford and the Somerville College Novelists, (New Brunswick: Rutgers University Press, 1989), 95-97.
} 
devastating effects higher education would have on the minds of women and the destruction such education would bring upon the traditional English family, in spite of Reid's desire to help women become better wives and mothers through education. In 1873, Spencer published a "Study of Sociology" which compared the minds of men and women, so as to show emphatically the incapability of the latter even to be able to process schooling and information as men's did.

That men and women are mentally alike, is as untrue as that they are alike bodily. Just as certainly as they have physical differences which are related to the respective parts they play in the maintenance of the race, so certainly as they have physical differences similarly related to their respective shares in the rearing and protection of offspring. ${ }^{231}$

Spencer also asserts that just as men and women's bodies had evolved differently in order to cope with their different biological requirements and surroundings, so also have their minds. "If we trace the genesis of human character, by considering the conditions of existence through which the human race passed in early barbaric times and during civilization, we shall see that the weaker sex naturally acquired certain mental traits by its dealings with the stronger."232 By this of course, Spencer means that while men's minds evolved better to handle the business of war and civilization, women's minds evolved so that they were best capable of caring for and nurturing men and their offspring.

A year later in 1874, Herbert Maudsley would take Spencer's arguments a step further. While Spencer attempted to prove there was a biological difference between

\footnotetext{
${ }^{231}$ Henry Spencer, "Study of Sociology" in Katharina Rowold, ed., Gender and Science: Late Nineteenth Century Debates on the Female Mind and Body, (Bristol: Thoemmes Press, 1996), 22. 232 Ibid, 26.
} 
the brains of men and women, Maudsley was intent on showing how that difference meant women were incapable of learning on the same scale as men. In his article "Sex in Mind and in Education," he claims the supporters of women in higher education had given little thought as to the consequences of their actions, which would eventually be detrimental to a woman's body. If women insisted upon being educated, Maudsley's solution for avoiding any devastation to their health was to formulate an educational plan to fit the different mental functions of a woman, instead of schooling them in the same manner as boys and men. Such a plan would pay particular attention to training for a woman's "foreordained work as mothers and nurses of children" as "they cannot be relieved from the performance of those offices so long as it is thought necessary that mankind should continue on earth." ${ }^{, 233}$ Furthermore, since women are far more mentally fit to be the educators of children than men are, the focus of women's continued education should be aimed toward the caring and nourishment of children and infants. Lastly, women's education should emphasize her place in nature as "the helpmate and companion of man in mental and bodily union." 234 As this last assertion of Maudsley's is very similar to Reid's stated reasons for improving women's education, this statement can be viewed as another example of contemporaneous scholars dismissing or overlooking Bedford College. Yet if Maudsley was not ignoring Bedford, such a statement could either indicate he was unaware of Reid's opinions towards women's education, or that he felt the decision of University of

\footnotetext{
${ }^{233}$ Herbert Maudsley, "Sex in Mind and in Education" in Katharina Rowold, ed., Gender and Science: Late Nineteenth Century Debates on the Female Mind and Body, (Bristol: Thoemmes Press, 1996), 38. ${ }^{234}$ Ibid, 39-40.
} 
London to confer degrees upon women negated the original intentions behind Bedford. Given that Maudsley makes no direct mention of Reid's College it is most likely he had dismissed Bedford, and was unaware of its founder's opinions on women's education.

Following the publication of Spencer and Maudsley's articles, there was a significant cry of outrage and protest from those involved with the women's higher education movement. After the printing of Maudsley's article, Elizabeth Garrett Anderson, a close friend of Emily Davies and a future member of Girton College's Council, published a reply in same journal. While Anderson takes offense at most of Maudsley's writings, she is particularly angered by his assumption that the goal of educating women was "to assimilate the female to the male mind." On the contrary, she asserts,

The single aim of those anxious to promote a higher and more serious education for women is to make the best they can of the materials at their disposal, and if they fail, it assuredly will not be from thinking that the masculine type of excellence includes all that can be desired in humanity. ${ }^{235}$

Anderson goes on to refute each of Maudsley's scientific proofs with evidence of her own from other professionals in physiology and biology and attacks his views on an ideal outline for women's education. She ends her article by addressing any of Maudsley's readers who may have been swayed by his fears, stating, "Nature in the long run protects herself from our mistakes; and when we are in

\footnotetext{
${ }^{235}$ Elizabeth Garrett Anderson, "Reply to Sex in Mind and in Education" in Katharina Rowold, ed., Gender and Science: Late Nineteenth Century Debates on the Female Mind and Body, (Bristol: Thoemmes Press, 1996), 54-55.
} 
doubt, we may be guided by the general principles of equality and common sense, while waiting for the larger light of experience." ${ }^{236}$ Similar articles and works were published attempting to dismiss the arguments laid down by Spencer and Maudsley; however, they appear to have had little impact on those who feared the implications of women in higher education.

Proponents of the movement continued to fight against the notion that women in higher education were dangerous. In 1887, a group of men and women from the women's colleges at Oxford and Cambridge formed a committee, headed by Henry Sidgwick, to repeat an experiment performed by the American Association of Collegiate Alumnae two years earlier. This experiment proved that college-educated women in the United States were no less healthy than their non-educated counterparts, in direct contrast to the opinions of Spencer and Maudsley. The Sidgwick Committee set about performing its own study, and sent out a questionnaire to 600 women who had either gone through two to three years of college or obtained a degree, as well as a second survey for them to give to a female relative close in age who had not attended College. In the end, 566 students responded as did 450 of their sisters or cousins with results that should have been enough to assuage any fears held by Spencer, Maudsley or their followers. The Sidgwick Report found that the marriage rate for students and their female relatives between the ages of twenty and thirty were almost identical; students had a lower proportion of childless marriages than their counterparts and

\footnotetext{
${ }^{236} \mathrm{Ibid}, 68$.
} 
students had a higher average number of children born per year of marriage. ${ }^{237}$ The fight for and against women in higher education was not resolved easily or quickly, however, as reiterations of these same arguments would be carried on well into the twentieth century, repeated when the women's colleges of Cambridge and Oxford petitioned their Universities for full incorporation and again years later, when women demanded full-fledged degrees.

Meanwhile, life at Bedford College continued on in relative peace and prosperity. By 1895, student enrollment had topped 200 and income had reached an astounding $£ 7,000$ a year, the increase of both likely helped by the establishment of the women's colleges at Cambridge and Oxford. ${ }^{238}$ Just as the foundation of those colleges had been eased by the support generated with the establishment of Bedford, so too did the foundation of the earlier women's colleges help to bring greater attention to women in higher education. The decision of the University of London to confer degrees upon women also contributed to Bedford's rising numbers, as it was the only University in England where women could earn such a distinction for many years.

Another result of the University of London's degrees was the demand by Bedford's students for even more extended instruction and advanced lectures. In 1889, an Advanced Mathematics course was established, which would have undoubtedly pleased the College's first mathematics professor, Augustus De Morgan. ${ }^{239}$ The

\footnotetext{
${ }^{237}$ Burstyn, 151-152.

${ }^{238}$ Tuke, Chart I, n.p., and Chart V, n.p.

239 De Morgan died of a "nervous prostration" in 1871 following the deaths of two of his children. Tuke, 130; Crook, 23.
} 
College also began to thrive outside of its academics. In December of 1886, the first issue of Bedford College Magazine was published and a number of student clubs and societies were formed, including a debating society and rowing and lawn-tennis clubs. A year later, the College earned another milestone when, after a group of students put on a production of Iphigenia in Taurus, Bedford became the first women's college to perform a play in Greek. In order to accommodate these new ventures, student fees were raised and an endowment was established by the members and friends of the College. ${ }^{240}$ While the creation of these social clubs were made possible by the increased student population and income of the College, these societies created an attraction that in turn, caused an influx in enrolment and tuition.

About this same time, the Trustees and the Council began to notice a problem with the College. Even though Bedford had been in operation for over thirty-five years, by 1884 there was still no Dean/Head/Principal to whom the students might turn for advice about their studies or courses. The closest position was the Lady Superintendant, but her job description had more to do with fees, discipline and household management, and she only had limited contact with the student's courses. An informal committee had been formed in 1882 by volunteer Lady Visitors to help students, but it quickly became apparent they were not prepared to advise those who were planning to apply for a degree from the University of London. ${ }^{241}$ Though they recognized the problem, the Council was slow to implement a solution. In 1887 a College Board of Education was formed, with William Shaen named as Chairman.

\footnotetext{
${ }^{240}$ Bentley, 23.

${ }^{241}$ Crook, 25.
} 
This position, an equivalent of the Principals of Girton and Newnham, proved to be a valuable asset to the College, as did Shaen, who had been an important member of Bedford for several years, and continued to be until his death in $1889 .{ }^{242}$ Lucy Russell took over the position following his decease, and she continued to elevate the position and the College. With the help of Henrietta Busk, she formed the College's Library Committee in 1892 and the Bedford College Students' Association in 1894 and helped to organize the College's Jubilee Celebration in 1899.

Before any of this however, Russell helped convince the Council to build a new wing of the College in the memory of her predecessor. A few years prior, the leases for three small adjoining houses had been purchased for use as laboratories for biology, chemistry and physics. The proposed new wing was to connect all three houses to the Central Hall of Bedford. Construction began in 1890 and was ready to open a year later in 1891. The overall success of the College had reached new heights and its role in advancing women in higher education had gained the attention of members of the elite, including the Royal family. As a result, the celebratory opening of the Shaen Wing was marked by Bedford's first Royal Visit as the Empress Frederick, daughter of Queen Victoria and wife of the German Emperor Frederick III, presided over the ceremony. ${ }^{243}$ Finally, forty-two years after its opening, Bedford College had gained the widespread approval and Royal support it had been denied for so long as an "unorthodox" and "highly suspicious" institution. However, had she still

\footnotetext{
${ }^{242}$ Tuke, 140.

${ }^{243}$ Bentley, 24-25.
} 
been alive, Elisabeth Reid would no doubt have remarked on the overall tardiness of the visit, believing it should have occurred years earlier.

In 1893, the College appointed Emily Penrose to be the first Principal of Bedford, allowing Russell to work more on administration and someone new to focus more attention on the students. Penrose had previously been Head of the Ancient History department and was a former student of Girton College. Following her appointment, even more clubs and societies were formed, and student enrollment and income spiked, reaching the high numbers mentioned above. This increase was maintained and afterwards the attendance grew continually, which meant more funds were available to the College, allowing for more books for the library, better equipment for the laboratories and better facilities for the students and the Professors. ${ }^{244}$ The years following Penrose's appointment led to another pivotal point in the College's history, when it was incorporated into the University of London's collegiate system.

By this time, the University of London had long been established as a degreegranting institution only, and as noted earlier, had been receiving a fair amount of criticism from the educational community over its lack of quality control. Possibly as a result, it began exploring the viability of becoming a teaching university. ${ }^{245}$ In the twenty years since first allowing women to receive degrees, more than half of Bedford's students were receiving a Bachelor degree every year, and three had

\footnotetext{
${ }^{244}$ Busk, 19-21.

${ }^{245}$ Crook, 23.
} 
received Doctoral degrees. ${ }^{246}$ By January of 1899 , a proposal was set before the Bedford Council to ask the College to join the University's small collegiate system. The recognition process proceeded relatively smoothly and in 1900, Bedford College was made an official member of the University of London's collegiate system. ${ }^{247}$

Although the final thirty years of the nineteenth century were not quite as strenuous for Bedford as its first twenty years had been, they were a time of many important events for the College, several of which occurred outside the walls of York Place. The University of London's decision to confer degrees upon women who were the students of Bedford may have been the most important affirmation of the College in the later years of the nineteenth century. Not only did this allow for nine of Bedford's students to become the first women in England to earn Bachelor degrees, it also helped increase the College's credibility along with student numbers and income.

The year 1869 had marked the beginning of a wave of establishments of new colleges for women, starting with Cambridge's Girton College, followed closely by Newnham in 1871 and a few years later by Lady Margaret Hall and Somerville at Oxford. In contrast to the difficulties experienced by the founders of Bedford, this chapter examined the mostly unencumbered establishment process of the women's colleges that followed had, which still faced obstacles to full incorporation into the universities, with which they were affiliated. Though their foundations were helped by the support of the women's higher education movement, these colleges faced the same questions that Reid and her fellow founders had faced, including justification of its

\footnotetext{
${ }^{246}$ Tuke, 158-162.

${ }^{247}$ Ibid, 187-191.
} 
existence, the religion of its students, and how to impart advanced education. Despite their challenges, their progress toward that ultimate goal was eased by learning from Bedford's previous difficulties and by the increasingly enthusiastic support of the women's higher education movement. As more colleges for women were established, the notion of women in higher education grew less radical. Just as it had been ahead of the pack in nearly every other aspect, Bedford College was the first to be incorporated with a university collegiate system when it became a member of the University of London in 1900. This incorporation was the culmination of fifty years of hard work and pure determination in the face of prejudice and opposition and marked the beginning of a new chapter in Bedford's history. 
"Leaves of Many Shapes and Colours":

\section{$\underline{\text { Conclusion }}$}

Within her-let her make herself her own

To give or keep, to live and learn and be

All that not harms distinctive womanhood.

For woman is not undevelopt man,

But diverse: could we make her as the man,

Sweet Love were slain.

-The Princess, Act VII

In the introduction to her work, A History of Bedford College for Women, 1849-1937, Dame Margaret Tuke invited her readers "to picture Mrs. Reid returned to earth for a few hours on a visit to the College which ninety years ago she conceived."248 Tuke supposed that while Reid would have been proud of the accomplishments Bedford had achieved in the years since her death, she would also have felt "certain dismay" as she observed "hatless students hurrying down to the lake in their boating-shorts," and the "ways of thought in the modern world...would [have] grieve[d] [and] even horrif[ied] her." Furthermore, Tuke suggests Reid might have been disappointed "the little acorn she had planted [had] become not the sober evergreen oak of her fancy, but a spreading tree with leaves of many colours and shapes. ${ }^{, 249}$ However, changing ideas of decorum aside, it is difficult to believe that if such an otherworldly visit were to occur, Elisabeth Reid would look over the history

\footnotetext{
${ }^{248}$ Tuke, $x v$.

${ }^{249}$ Ibid, $x v-x v i$.
} 
of her college with anything but a deep sense of pleasure and honor over all it had achieved, hatless heads and boating shorts aside.

By the mid-nineteenth century, more and more women were becoming involved in the public and political spheres. Finding causes that were deemed socially "safe and respectable," women used their assigned role as the moral compass of society to bring attention to their chosen movements. ${ }^{250}$ One important focus for women's attention was their interest in reforming the state of education in England, especially the schooling given to girls and young women. Most young children at this time were initially educated at home, but boys usually received additional training in the form of day schools, followed by secondary and university education. Girls, on the other hand stayed at home with their mothers or governesses, learning the household skills they would need one day to be good wives and mothers. ${ }^{251}$ The dissatisfaction women felt with the state of female education eventually contributed to the foundation of the Governesses Benevolence Institution. After a few years of operation, the organization formed Queen's College under the leadership of F.D. Maurice. ${ }^{252}$ Though more of a day training school than a college, Queen's proved to be an important step towards the establishment of Bedford College eighteen months later.

Encouraged by the successful foundation of Maurice's school, Reid opened her own College for women in 1849. Unlike the earlier institution, Bedford College would be open to any girl who wished to join, regardless of her religion or her family's

\footnotetext{
${ }^{250}$ Cf. Reynolds, Chapter 1; Shiman.

${ }^{251}$ Davidoff and Hall, 54-65.

${ }^{252}$ Burstyn, 23-25; Grylls, 10-15.
} 
financial status. However, while Queen's College received royal patronage and the support of the Church of England, the Unitarian Reid and her likeminded followers were viewed with a fair amount of suspicion, and Bedford was often labeled as unorthodox. As such, it was often difficult to secure funds, students or professors for the College. Within its first two decades of existence, Bedford faced closure and bankruptcy a number of times. Other than monetary troubles, the founders of the College, and the professors in particular, found the task of educating their new charges especially difficult during these early years. All of Bedford's professors also taught at other institutions, and were used to their students' possessing a certain level of education. As a solution, Reid and the Council created the Bedford Junior School to provide prerequisite courses necessary for entering college. ${ }^{253}$

Concurrent with the establishment of Bedford, the women's higher education movement, comprised of women and men connected to Bedford and Queen's Colleges, came into being. Though it lacked the central organizing effort of earlier movements, the women's higher education movement carried the momentum of the social ferment created by the women who had been slowly entering the public sphere through safe and respectable means and movement in the preceding decades. ${ }^{254}$ This movement generated support for Reid's college, and combined with Bedford to provide the impetus for the women's colleges associated with Cambridge and Oxford to come.

\footnotetext{
${ }^{253}$ Tuke, $50-68$.

${ }^{254}$ Burstyn, 25-35.
} 
From the women's higher education movement and Bedford College, came Emily Davies, who in 1869 founded Girton College, where women could learn, taking exactly the same courses as the male students of Cambridge University; Newnham College quickly followed, opening in 1871. The women's colleges of Oxford, Lady Margaret Hall and Somerville were established just a decade later, in 1878. While all of these later colleges were connected in name with either Cambridge or Oxford, it would be well into the twentieth century before they were made official members of the Universities and their students were allowed to earn degrees. ${ }^{255}$ Long before this, the University of London began conferring degrees upon women who had received the required amount of education from Bedford College. In 1878, current and former students of Bedford became the first women in England to receive Bachelor of Arts degrees. ${ }^{256}$ The end of the century ended one chapter of Bedford's history and opened another, as it was incorporated into the University of London's collegiate system.

In 1899, a few months before Bedford College would become an official part of the University of London's collegiate system, Meta Brock had written an open letter to the College Council, expressing her fond memories as a student thirty-eight years earlier. Among her reminiscences on courses, Lady Visitors, professors and other students, she comments on the "most valuable legacy" of the College. "Everywhere Bedford College influence has stimulated the old students to work for women's advancements, socially and intellectually, everywhere they have given a

\footnotetext{
${ }^{255}$ In fact, it would be 1920 before Lady Margaret Hall and Somerville became official colleges of Oxford, and 1947 before Girton and Newnham were incorporated into Cambridge. Dyhouse, 150-160. 256 Tuke, 125-128.
} 
helping hand to improve her position."257 For Brock, one of the most important products of Bedford College, other than providing new educational opportunities for women, was the creation of a social network of former students, nearly all of whom participated in the fight for the improved status for women in some fashion or another, either in higher education, suffrage or working rights. For instance, Elizabeth Blackwell (Class of 1853) was the first female doctor in the United States, the first woman to be listed on the United Kingdom Medical Register and a prominent figure in the women's rights movement; ${ }^{258}$ Dinah Maria Craik (Class of 1854) was a notable English novelist and poet who often contributed articles to magazines advocating for women's suffrage ${ }^{259}$ Beatrice Harraden, (Class of 1885) was a British novelist and notable suffragette who was a member of the Women's Social and Political Union, the Women's Tax Resistance League and the Women Writer's Suffrage League; ${ }^{260}$ Ada Stair Perry (Class of 1902) was the Secretary of the Yorkshire Ladies' Council of Education from 1907 to 1913 and the Superintendent of the YWCA in Edmonton, Canada in 1913 and at the YWCA in Dunedin, New Zealand from 1921 to $1924 ;^{261}$ and Dame Margaret Miles (Class of 1933) was a pioneer of comprehensive education and the Headmistress of one of the first girl's comprehensive schools. ${ }^{262}$ Of course, these are only a few of the impressive students who emerged from Bedford College in

\footnotetext{
${ }^{257}$ Meta Brock to Bedford College, London (For Women), 1899. RHUL Archives, PP 60/2/1/1/3/16.

${ }^{258}$ Tuke, 281-282.

${ }^{259}$ Ibid, 303.

${ }^{260}$ Bentley, 35.

${ }^{261}$ Tuke, 309.

262 Crook, 107.
} 
its more than 150 years of existence, and regrettably this is one of the least-explored topics of this thesis.

While this thesis has filled some of the gaps left by previous scholarships, there are still several areas of study that would greatly benefit from additional research. Due mostly to a lack of available sources, this thesis does not include a thorough analysis of the students and their motivations for attending Bedford College, especially in the decades before the University of London's decision to grant degrees to women. Similarly, the specific activities of the Lady Visitors have not been adequately explored. While the effects of the criticism of women in higher education were marginally addressed in this thesis, further scholarship on their direct effect on Bedford and its students might also provide a deeper understanding of the critics' rationales.

Just as the students of the College had been leading figures in the fight for women's rights and education, so too has the institution itself been a forerunner in the ever-growing field of women's education. In her work, historian Carol Dyhouse notes that women represented around fifteen per cent of students in British Universities in 1900 , rising to twenty-three per cent by $1939 .^{263}$ According to recent figures released by the Higher Education Statistics Agency of England, females made up almost fiftyfive per cent of full time undergraduate and postgraduate students in the 2009/2010 school year. ${ }^{264}$ While these achievements cannot be placed solely on the shoulders of

\footnotetext{
263 Dyhouse, 7.

${ }^{264}$ Higher Education Statistics Agency, Students in Higher Education Institutions, (London: HESA Publishing, 2011), Table A, 35; Table C, 40; Table D, 49.
} 
Elisabeth Reid and women's higher education movement, this combination certainly was a significant driving force behind the growing acceptance women in higher education. 
Works Cited

Primary Sources

\section{$\underline{\text { Manuscript Sources }}$}

Bostock, Elizabeth Ann. Letter to Elisabeth Jesser Reid, 1855. RHUL Archives, BC RF 103/1/17.

. Letter to Elisabeth Jesser Reid, 1856. RHUL Archives, BC RF 103/1/43.

. Letter to Elisabeth Jesser Reid, 1865. RHUL Archives, RF 103/1/29.

Brock, Meta. Letter to Bedford College, London (For Women), 1899. RHUL Archives, PP 60/2/1/1/3/16.

Council Minutes, April 20, 1856. RHUL Archives, 157/3/26.

Davies, Emily. Letter to Anna Richardson, June 25, 1868. In Emily Davies Collected Letters, 1861-1875, 282-283. Edited by Ann B. Murphy and Deirdre Raftery. Charlottesville: University of Virginia Press, 2004.

Last Will and Testament of Mrs. Elisabeth Jesser Reid. RHUL Archives, GB 100/1/2.

Lease of No. 47 Bedford Square, 1852. RHUL Archives, AR 415/3/2.

Markay, R.W. Letter to Elisabeth Jesser Reid, 1850. RHUL Archives, RF 103/8/20.

Reid, Elisabeth Jesser. Letter to Sophia Elizabeth De Morgan, Feb. 1849. RHUL Archives, RF 103/3/4.

. Letter to Sophia Elizabeth De Morgan, May 22, 1849. RHUL Archives RF $103 / 3 / 1$.

. Letter to Lady Visitors, April 30, 1852. RHUL Archives, RF 103/2/24.

. Letter to Henry Crabb Robinson, March 1858. In Dairy, Reminiscences and Correspondences: of Henry Crabb Robinson, edited by Henry Crabb

Robinson, Augustus De Morgan and Thomas Sadler, 374. Oxford: Riverside Press, [n.d.].

. Letter to Jane Martineau and Elizabeth Ann Bostock, 1860. In Margaret Tuke, A History of Bedford College for Women, 1849-1937, 317. Oxford: Oxford University Press, 1939. 
Prospectus of Junior School. RHUL Archives, RF 155/1/1.

Robinson, Henry Crabb. Letter to Elisabeth Jesser Reid, Nov. 6, 1856. RHUL Archives RF 103/4/19.

. Letter to Elisabeth Jesser Reid, Jan. 1, 1852. RHUL Archives RF 103/4/11.

. Letter to Thomas Robinson, July 7, 1842. In Dairy, Reminiscences and Correspondences: of Henry Crabb Robinson, edited by Henry Crabb

Robinson, Augustus De Morgan and Thomas Sadler, 295. Oxford: Riverside Press, [n.d.].

\section{$\underline{\text { Printed Primary Sources }}$}

Anderson, Elizabeth Garrett. "Reply to Sex in Mind and in Education". In Gender and Science: Late Nineteenth Century Debates on the Female Mind and Body. Edited by Katharina Rowold. Bristol: Thoemmes Press, 1996.

Anonymous, "Sex in Mind and in Education" In Gender and Science: Late Nineteenth Century Debates on the Female Mind and Body. Edited by Katharina Rowold. Bristol: Thoemmes Press, 1996.

Busk, Henrietta. Short History of Bedford College (for Women). London: Baker St., 1899.

Calendar of Bedford College, London, 8 \& 9 York Place: Printed for the Council. London: Spottiswoode \& Co., 1888.

Davies, Emily. The Higher Education of Women. London: Alexander Strahan, 1866. . Thoughts on Some Questions Relating to Women, 1860-1908. Cambridge: Bowes \& Bowes, 1910.

Hudson, Derek, ed. The Diary of Henry Crabb Robinson: An Abridgement. London: Oxford University Press, 1967.

Maurice, Rev. Frederick Denison. “Queen's College, London: Its Objects and Methods." In Introductory Lectures, Delivered at Queen's College, London. London: John W. Parker, West Strand, 1849.

Maudsley, Herbert. "Sex in Mind and in Education". In Gender and Science: Late Nineteenth Century Debates on the Female Mind and Body. Edited by Katharina Rowold. Bristol: Thoemmes Press, 1996. 
Murphy, Ann B. and Deirdre Raftery, eds. Emily Davies Collected Letters, 1861 1875. Charlottesville: University of Virginia Press, 2004.

Robinson, Henry Crabb, Augustus De Morgan and Thomas Sadler. Diary, Reminiscences, and Correspondence: Of Henry Crabb Robinson. Oxford: Riverside Press, [n.d].

Romanes, George J. Founding of Queen's College. (1850). In The Education Papers: Women's Quest for Equality in Britain, 1850-1912. Spencer, Dale, ed. New York: Routledge, 1987.

Spencer, Henry. "Study of Sociology". In Gender and Science: Late Nineteenth Century Debates on the Female Mind and Body. Edited by Katharina Rowold. Bristol: Thoemmes Press, 1996.

\section{Secondary Sources}

Adams, Pauline. Somerville for Women: An Oxford College, 1879-1993. Oxford: Oxford University Press, 1996.

Bailey, Gemma Creighton. Lady Margaret Hall: A Short History, Issued on Behalf of the Lady Margaret Hall Appeal Fund. London: Oxford University Press, 1923.

Bentley, Linna. Educating Women: A Pictorial History of Bedford College, University of London, 1849-1985. London: Alma Publishers, 1991.

Bradbrook, M.C. 'That Infidel Place': A Short History of Girton College, 1869-1969. London: Chatto \& Windus, 1969.

Breuing, Charles. The Age of Revolution and Reaction, 1789-1850. New York: Newton, 1970.

Brittain, Vera. The Women at Oxford: A Fragment of History. New York: Macmillan, 1960.

Burnette, Joyce. Gender, Work and Wages in Industrial Revolution Britain. Cambridge: Cambridge University Press, 2008.

Burstyn, Joan N. Victorian Education and the Ideal of Womanhood. London: Croom Helm, 1980. 
Chase, Malcolm. Chartism: A New History. New York: Manchester University Press, 2007.

Clapp-Itnyre, Alisa. "Marginalized Musical Interludes: Tennyson's Critique of Conventionality in The Princess." Victorian Poetry, Volume 38, No. 2 (Summer, 2000): 227-248.

Crook, J. Mordaunt, ed. Bedford College: University of London: Memories of 150 Years. Egham: Royal Halloway \& Bedford New College, 2001.

De Bellaigue, Christina. Educating Women: Schooling and Identity in England and France, 1800-1867. Oxford: Oxford University Press, 2007.

Davidoff, Leonore and Catherine Hall. Family Fortunes: Men and Women of the English Middle Class, 1780-1850. London: Routledge, 1988.

Drescher, Seymour. Abolition: A History of Slavery and Antislavery. Cambridge: Cambridge University Press, 2009.

Dyhouse, Carol. No Distinction of Sex? Women in British Universities, 1870-1939. London: UCL Press, 1995.

Eschbach, Elizabeth Seymour. The Higher Education of Women in England and America, 1865-1920. New York: Garland Publishing, Inc., 1993.

Fasick, Laura. "The Reform of Women's Education in Tennyson's The Princess and Gilbert and Sullivan's Princess Ida." In Gender and Victorian Reform, edited by Anita Rose, 26-45. Cambridge: Cambridge Scholars Press, 2008.

Gardner, Alice. A Short History of Newnham College Cambridge. Cambridge: Bowes \& Bowes, 1921.

Green, Laura Morgan. Educating Women: Cultural Conflict and Victorian Literature. Athens: Ohio University Press, 2001.

Grylls, R. Glynn. Queen's College: 1848-1948, founded by Frederick Denison Maurice. London: George Routledge \& Sons, Ltd., 1948.

Halbersleben, Karen I. “'She Hath Done What She Could:' Women's Participation in the British Antislavery Movement, 1825-1870." PhD diss., State University of New York at Buffalo, 1987.

Hall, Catherine. White, Male, and Middle-Class: Explorations in Feminism and History. New York: Routledge, 1992. 
Hall, Catherine, Keith McClelland and Jane Rendall. Defining the Victorian Nation: Class, Race, Gender \& the Reform Act of 1867. Cambridge: Cambridge University Press, 2000.

Hamilton, Mary Agnes. Newnham: An Informal Biography. London: Faber and Faber, 1936.

Hilton, Mary and Pam Hirsch, eds. Practical Visionaries: Women, Education \& Social Progress, 1970-1930. London: Longman Publishing, 2000.

Hole, Robert. Pulpits, Politics and Public Order in England, 1760-1832. Cambridge: Cambridge University Press, 1989.

Kaye, Elaine. A History of Queen's College, London, 1848-1972. London: Chatto \& Windus, 1972.

Lannon, Frances. Lady Margaret Hall, Oxford: the First 125 Years, 1879-2004. Oxford: Lady Margaret Hall, 2004.

Leonardi, Susan J. Dangerous by Degrees: Women at Oxford and the Somerville College Novelists. New Brunswick: Rutgers University Press, 1989.

Levine, Philippa. Feminist Lives in Victorian England: Private Roles and Public Commitment. Oxford: Basil Blackwell, 1990.

Martin, Jane. Women and the Politics of Schooling in Victorian and Edwardian England. London: Leicester University Press, 1999.

Martin, Jane and Joyce Goodman. Women and Education, 1800-1980 London: Palgrave, 2004.

Nash, David. Blasphemy in the Christian World: A History. Oxford: Oxford University Press, 2007.

Poovey, Mary. Uneven Developments: The Ideological Work of Gender in MidVictorian England. Chicago: The University of Chicago Press, 1988.

Reynolds, K.D. Aristocratic Women and Political Society in Victorian Britain. Oxford: Clarendon Press, 1998.

Robinson, Jane. Bluestockings: The Remarkable Story of the First Women to Fight for an Education. London: Viking, 2009. 
Rose, Anita, ed. Gender and Victorian Reform Cambridge: Cambridge Scholars Publishing, 2008.

Royle, Edward. Victorian Infidels: The Origins of the British Secularist Movement, 1791-1866. Manchester: University of Manchester Press, 1974.

Schroder, Paul W. "International Politics, Peace, and War, 1815-1914.” In The Nineteenth Century: Europe 1789-1914, edited by T.C.W. Blanning, 148-209. Oxford: Oxford University Press, 2000.

Shiman, Lilian Lewis. Women and Leadership in Nineteenth-Century England. New York: St. Martin's Press, 1992.

Sked, Alan. “The Metternich System, 1814-1848.” In Europe's Balance of Power, 1814-1848. Edited by Alan Sked, 52-65. London: Macmillan, 1979.

Stephen, Barbara Nightingale. Emily Davies and Girton College. 1927. Reprint, Westport: Hyperion Press, 1976.

Tennyson, Alfred Lord. The Princess and Maud. Vol. 4 of The Works of Alfred Lord Tennyson. London: Macmillan, 1908.

Tuke, Margaret. A History of Bedford College for Women, 1849-1937. Oxford: Oxford University Press, 1939.

Vickery, Margaret Birney. Buildings for Bluestockings: The Architecture and Social History of Women's College's in Late Victorian England. Newark: University of Delaware Press, 1999.

Watts, Ruth. Gender, Power, and the Unitarians in England: 1760-1860. London: Longman, 1998.

Webb, R.K. Harriet Martineau: A Radical Victorian. New York: Columbia University Press, 1960. 